
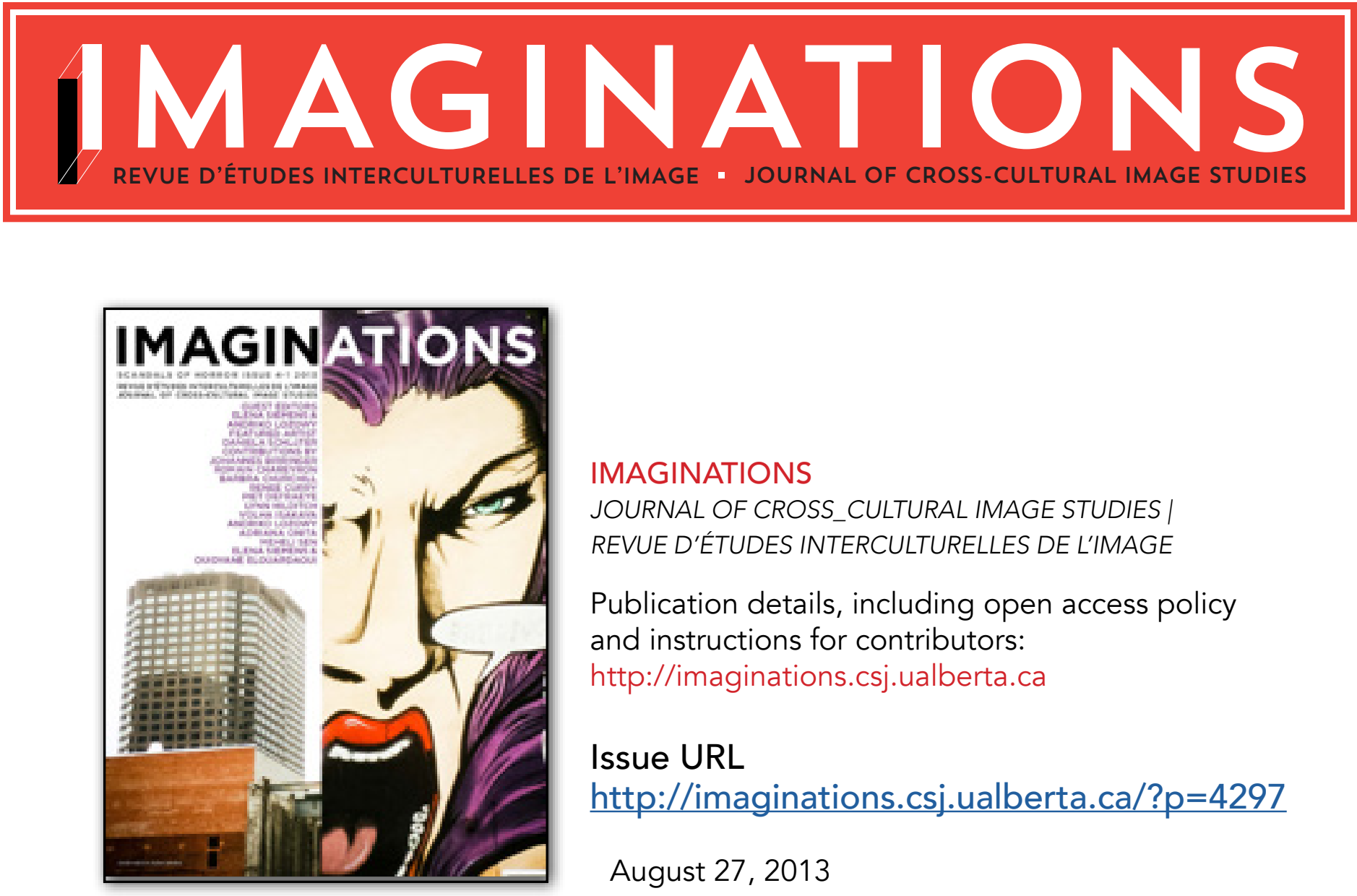

IMAGINATIONS

JOURNAL OF CROSS_CULTURAL IMAGE STUDIES |

REVUE D'ÉTUDES INTERCULTURELLES DE L'IMAGE

Publication details, including open access policy and instructions for contributors:

http://imaginations.csj.ualberta.ca

Issue URL

http://imaginations.csj.ualberta.ca/?p=4297

August 27, 2013

To link to this issue:

http://dx.doi.org/10.17742/IMAGE.scandal.4-1

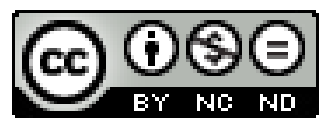

The copyright for each article belongs to the author and has been published in this journal under a Creative Commons Attribution NonCommercial NoDerivatives 3.0 license that allows others to share for non-commercial purposes the work with an acknowledgement of the work's authorship and initial publication in this journal. The content of this article represents the author's original work and any third-party content, either image or text, has been included under the Fair Dealing exception in the Canadian Copyright Act, or the author has provided the required publication permissions. 

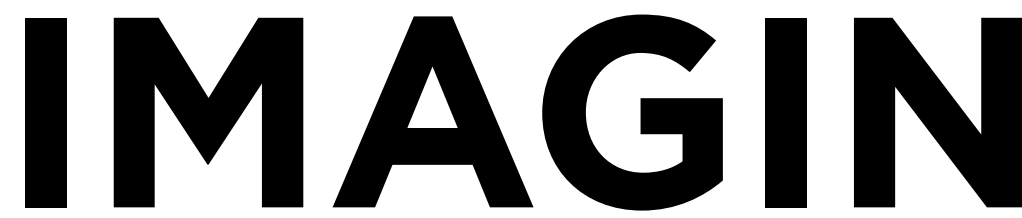

SCANDALS OF HORROR ISSUE 4-1 2013 REVUE D'ÉTUDES INTERCULTURELLES DE L'IMAGE JOURNAL OF CROSS-CULTURAL IMAGE STUDIES

GUEST EDITORS ELENA SIEMENS \& ANDRIKO LOZOWY FEATURED ARTIST DANIELA SCHLÜTER CONTRIBUTIONS BY JOHANNES BIRRINGER ROMAIN CHAREYRON BARBRA CHURCHILL RENEE CURRY PIET DEFRAEYE LYNN HILDITCH VOLHA ISAKAVA ANDRIKO LOZOWY ADRIANA ONITA MEHELI SEN

ELENA SIEMENS \& OUIDYANE ELOUARDAOUI

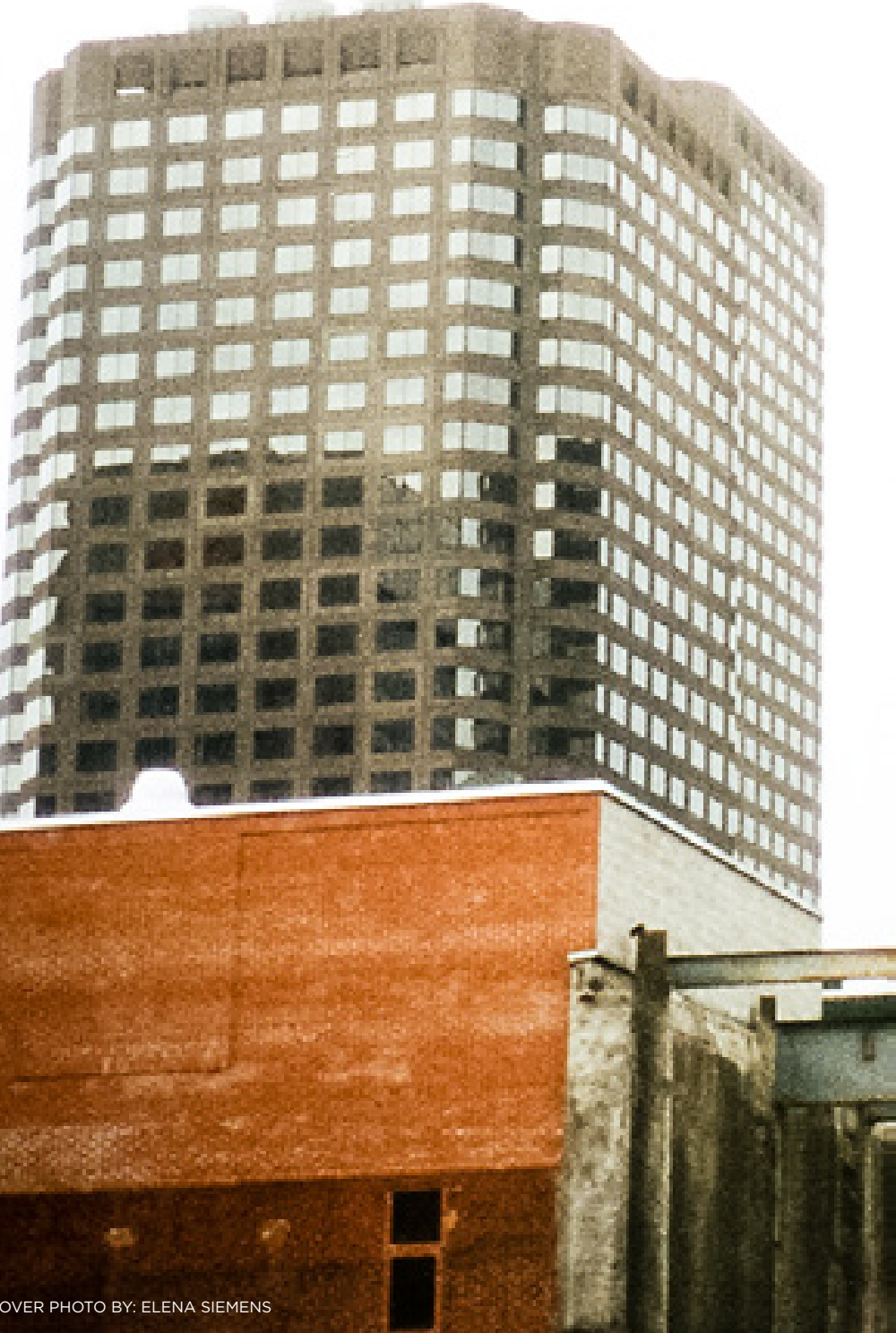

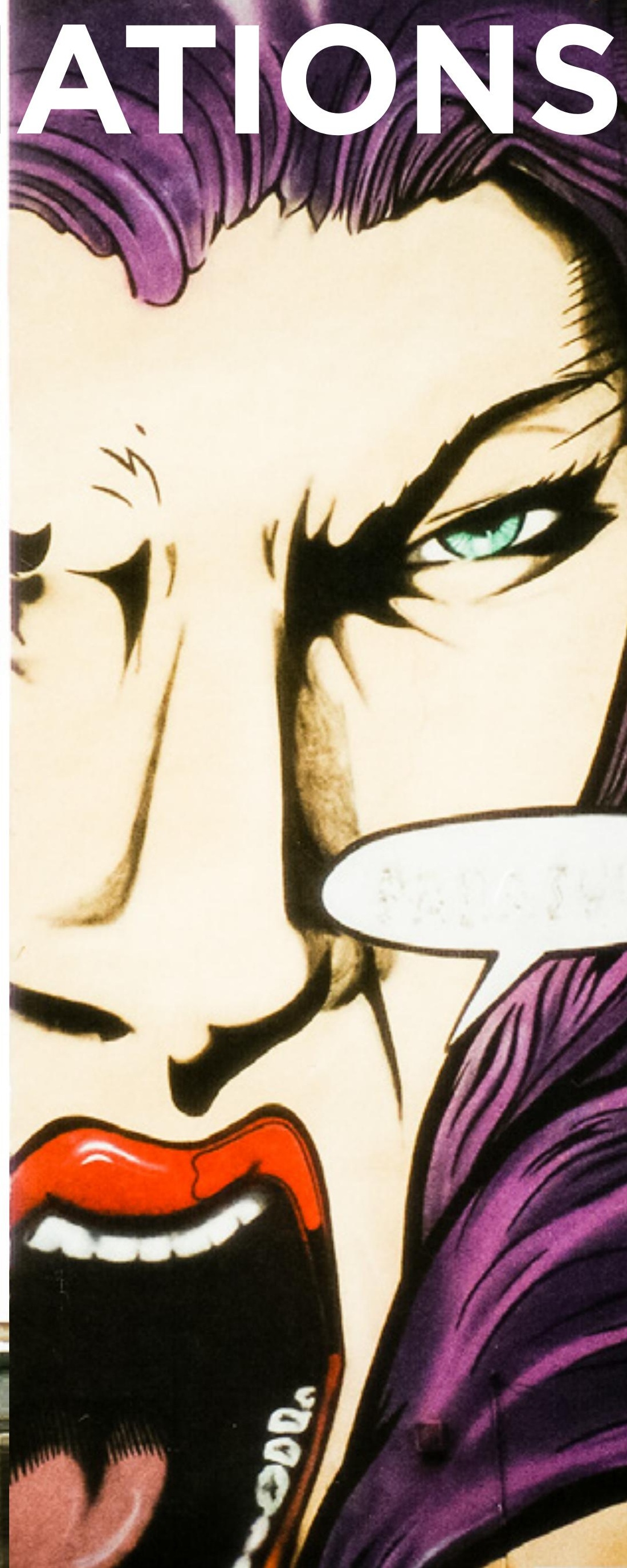


GUEST EDITOR • SCANDALS OF HORROR • ELENA SIEMENS

MANAGING EDITOR • ANDRIKO LOZOWY

EDITOR IN CHIEF | RÉDACTEUR EN CHEF • SHEENA WILSON

EDITORIAL TEAM | COMITÉ DE RÉDACTION:

DANIEL LAFOREST, DALBIR SEHMBY, CARRIE SMITH-PREI, ANDRIKO LOZOWY

FRENCH CONTENT EDITOR | CONTENU FRANÇAIS: DANIEL LAFOREST

COPY EDITOR | RÉVISIONS: DENNIS KILFOY

DESIGNER AND TECHNICAL EDITOR | DESIGN ET TECHNOLOGIE:

ANDRIKO LOZOWY

WEB EDITOR | MISE EN FORME WEB: CARRIE SMITH-PREI

REVIEWS EDITOR - ELICITATIONS | COMPTES RENDUS CRITIQUES

ÉLICITATIONS: TARA MILBRANDT

FRENCH TRANSLATIONS | TRADUCTIONS FRANÇAISES: ALEXANDRA POPESCU

EDITORIAL ADVISORY BOARD | COMITÉ SCIENTIFIQUE:

HESTER BAER, UNIVERSITY OF OKLAHOMA, UNITED STATES

MIEKE BAL, UNIVERSITY OF AMSTERDAM \& ROYAL NETHERLANDS

ACADEMY OF ARTS AND SCIENCES, NETHERLANDS

ANDREW BURKE, UNIVERSITY OF WINNIPEG, CANADA

OLLIVIER DYENS, CONCORDIA UNIVERSITY, CANADA

MICHĖLE GARNEAU, UNIVERSITÉ DE MONTRÉAL

WLAD GODZICH, UNIVERSITY OF CALIFORNIA SANTA CRUZ, UNITED STATES

KOSTA GOULIAMOS, EUROPEAN UNIVERSITY, CYPRUS

FAYE HAMMILL, UNIVERSITY OF STRATHCLYDE, UNITED KINGDOM

ANTON KAES, UNIVERSITY OF CALIFORNIA BERKELEY, UNITED STATES

DOMINIC MCIVER LOPES, UNIVERSITY OF BRITISH COLUMBIA, CANADA

SARAH MCGAUGHEY, DICKINSON COLLEGE, UNITED STATES

PETER MCISAAC, UNIVERSITY OF MICHIGAN, UNITED STATES

MARIE-DOMINIQUE POPELARD, UNIVERSITÉ DE LA SORBONNE

NOUVELLE - PARIS 3, FRANCE

CHRISTINE RAMSAY, UNIVERSITY OF REGINA, CANADA

LAURENCE A. RICKELS, ACADEMY OF FINE ARTS, KARLSRUHE, GERMANY

WILL STRAW, MCGILL UNIVERISTY, CANADA

IMRE SZEMAN, UNIVERSITY OF ALBERTA, CANADA

FOUNDING EDITORS: WILLIAM ANSELMI, DANIEL LAFOREST,

CARRIE SMITH-PREI, SHEENA WILSON

SPONSOR:

institut ditTUdes CANADIENAE:

CANRGIAN STUDIES NESTITUTE

LWWERTY CF ALESTR

IMAGINATIONS • ISSUE 3-2, 2012 • 2 
4-1, SUMMER 2013

ELENA SIEMENS

BLUE DOOR HAVANA

RENÉE R CURRY

BEAUTIFUL JUNKIES: IMAGES OF DEGRADATION IN REQUIEM FOR A DREAM

JOHANNES BIRRINGER

THE VALLEY OF THE SHADOW OF DEATH

LYNN HILDITCH

A SURREAL LANDSCAPE OF DEVASTATION: AN ANALYSIS OF

LEE MILLER'S GRIM GLORY PHOTOGRAPHS OF THE LONDON BLITZ

BARB CHURCHILL

HARD-BOILED TABLOID: HAPPILY LOW-BROW

VOLHA ISAKAVA

IN SEARCH OF AUTHENTICITY

TIME AND SPACE IN RUSSIAN HORROR FILM

MEHELI SEN

"WE ARE RESILIENT BY FORCE, NOT BY CHOICE"

TERRIFYING BOMBAY IN NEW BOLLYWOOD CINEMA

ADRIANA ONITA

MY LAST FOUR MINUTES ON PRINCE WILLIAM STREET

ROMAIN CHAREYRON

HORROR AND THE BODY: UNDERSTANDING THE REWORKING OF THE GENRE IN

MARINA DE VAN'S DANS MA PEAU/IN MY SKIN (2001)

PIET DEFRAEYE

THE RWANDAN GENOCIDE IN FILM, AND A SUNDAY IN KIGALI:

WATCHING WITH A PIERCED EYE

ARTIST INTERVIEW - DANIELA SCHLÜTER BY ANDRIKO LOZOWY \& ELENA SIEMENS

LIGHTING DARKNESS: A CONVERSATION WITH DANIELA SCHLÜTER

AND

OUIDYANE ELOUARDAOUI

CONTEMPORARY ARAB MUSIC VIDEO CLIPS: BETWEEN SIMULATING

MTV'S GENDER STEREOTYPES AND FOSTERING NEW ONES

FRONT COVER (2009) AND BACK COVER IMAGE (2012)

BY ELENA SIEMENS 

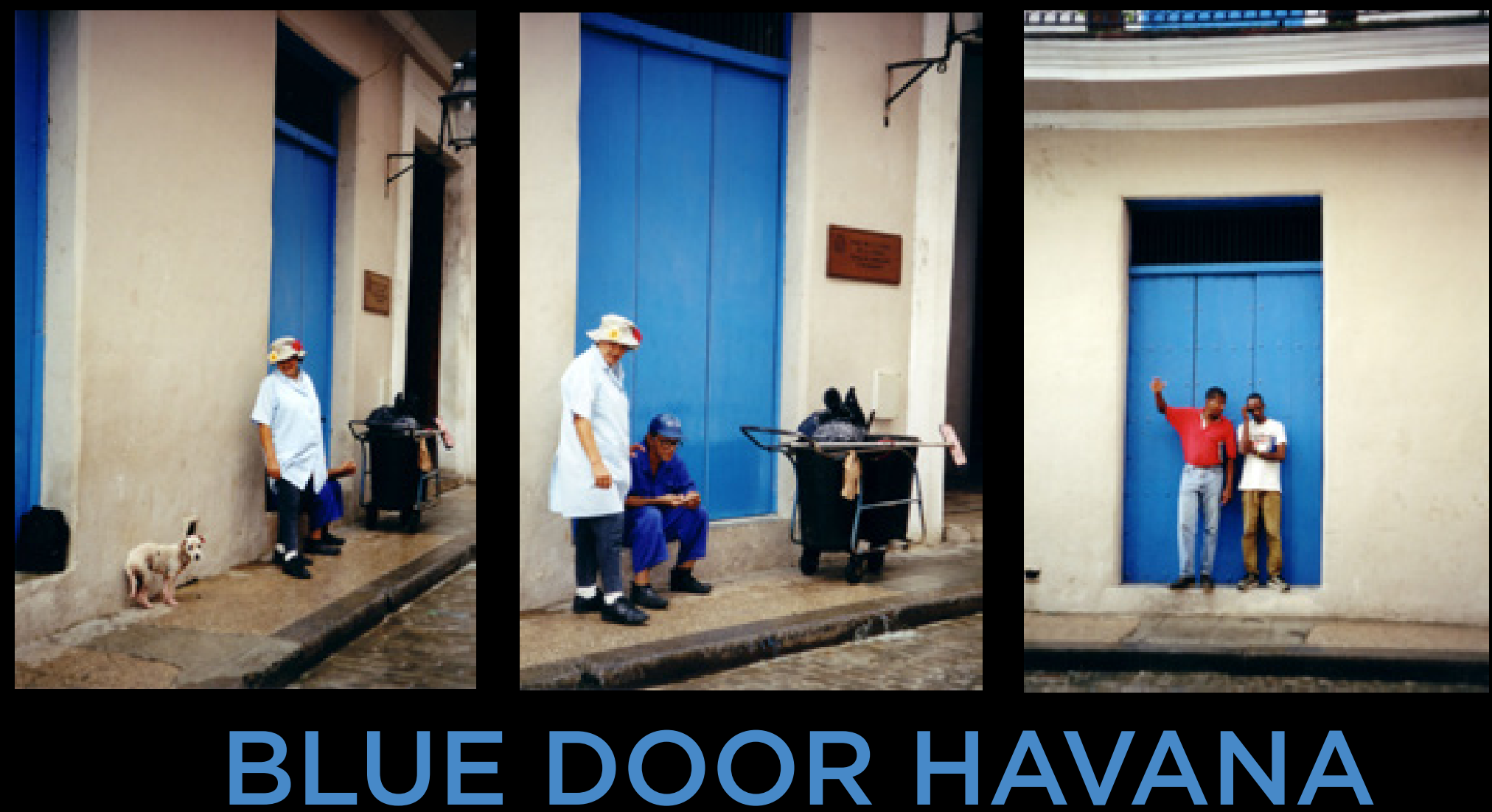

ELENA SIEMENS

This introductory piece to the themed issue on Scandals of Horror addresses Roland Barthes's essay "ShockPhotos," part of his celebrated volume on The Eiffel Tower and Other Mythologies. Drawing on Barthes and other relevant theorists, the present collection examines disturbing images in film and photography from around the globe, questioning their place in today's culture and their impact on the viewer. In "Blue Door Havana," I discuss Barthes's distinction between the "overconstructed" and "literal" representation of shocking events - an important distinction which also sheds light on images by Cuba's prominent revolutionary photographers Alberto Korda and Raul Corrales. I illustrate my piece with several snapshots of
Havana - their understated sensibility contrasting with Korda and Corrales, whose flamboyant pictures, inspired by glossy fashion magazines from the West, fall more easily into Barthes's category of the "overconstructed" photography.

It is a rainy morning in Havana. My fellow tourists dissipate, each in search of their own treasure. The setting is the complete opposite of our pristine seaside resort in Varadero. An old cathedral is under reconstruction with scaffolding and various construction equipment. I photograph a pretty square just outside the cathedral, capturing the wet trees and the wet pavement. Three old men in straw hats are playing folk songs. The building next to them has a set of tall bright-blue doors. In On Photography, 
Susan Sontag writes about "the beauty of the cracked peeling door" and how it appeals to the Western viewer, who appreciates "the picturesqueness of disorder" (362). Sontag contrasts this sensibility with that of Communist China, where photography was required to embellish reality.

I take no side in this divide, or rather, as a native Russian, I can relate to both. The blue doors in Havana attract me for a different reason. They remind me of a remarkable show staged in a doorway that I once saw in Moscow. Cuba, it appears, follows its own path, entirely different from either China or Russia. Capturing the revolution in Cuba, Alberto Korda employed "the same ideas and techniques as in fashion photography," Jaime Sarusky writes in his introduction to Korda's book of photographs (12). Korda's hero was the photographer Raul Corrales, who as a teenager devoured glossy foreign magazines, "whose photos made his imagination soar" (5). At the Havana airport, waiting for my flight back to Canada, I leaf through pictures by Korda and Corrales, in which Cuba's capital resembles a glamorous movie set: tropical nature, the sea, and handsome rebels in black berets marching on the old regime. In the 1930s Moscow, the revolutionary director Vsevolod Meyerhold hoped to construct a new theatre with a stage shaped like a catwalk. He was not able to realize his dream; palm trees do not grow in Russia.
In his essay "Shock-Photos" - the inspiration behind this collection of texts and images - Roland Barthes observes that "it is not enough for the photographer to signify the horrible for us to experience it" (71). Discussing the Shock-Photos exhibit at the Galerie d'Orsay in Paris, Barthes writes that most of the exhibited pictures failed to produce the desired effect. The photographer, he explains, "almost always overconstructed the horror he is proposing, adding to the fact, by contrasts and parallels, the intentional language of horror"(Barthes 71). Barthes cites several examples of this, including a picture which "places side by side a crowd of soldiers and a field of skulls" (Barthes 71). Another photograph depicts "a column of prisoners passing a flock of sheep" (Barthes 71). These "all too skillful" photographs, Barthes argues, take away an opportunity to reflect and judge, leaving the viewer with nothing but "a simple right of intellectual acquiescence” (71).

Barthes singles out a selection of newsagency photos, also displayed at the exhibit, in which "the fact, surprised, explodes in all of its stubbornness, its literality, in the very obviousness of its obtuse nature" (73). These newsagency shots depicting "the executed Guatemalans," or "the policeman's raised truncheon," Barthes points out, are "visually diminished, dispossessed of that numen which the painters would not have failed to add to them" (73). The "naturalness of these images," Barthes continues, "compels the spectator to a violent interrogation" 
(73). The viewers must themselves elaborate on the picture and place their own judgment - "without being encumbered by the demiurgic presence of the photographer" (Barthes 73). According to Barthes, these "visibly diminished" news-agency shots exhibit "that critical catharsis Brecht demands," rather than "an emotive purgation," characteristic of painting (73). "The literal photograph," Barthes concludes his essay, "introduces us to the scandal of horror, not to horror itself" (73). In what follows, the reader will find a selection of provocative essays dealing with both the "overconstructed" and "literal" representation of disturbing events. Alluding to Barthes and other influential thinkers, the essays explore diverse examples of "scandals of horror" - shocking images in film and photography drawn from a variety of historical eras and geographical locations from Bombay to Moscow to Rwanda.

\section{Works Cited}

Barthes, Rolland. "Shock-Photos." The Eiffel Tower and Other Mythologies. New York: Farrar, Straus and Giroux, 1988.

Sarusky, Jamie. "Raul Corales.” Ed. Carlos Torres Cairo, Raul Corales: La Imagen Y

La Historia, Florence: Aediciones Aurelia, 1996.

Sarusky, Jamie. "Korda." Ed. Carlos Torres Cairo, Alberto Korda: Diario de una Revolucion, Florence: Aediciones Aurelia, 1996.

Sontag, Susan. "Image-World." A Susan Sontag Reader. New York: Vintage Books, 1983.

Elena Siemens is Associate Professor in the Department of Modern Languages and Cultural Studies, University of Alberta. She is the author of Theatre in Passing: A Moscow Photo-Diary (Intellect 2011), and editor of two forthcoming collections of essays, The Dark Spectacle: Landscapes of Devastation in Film and Photography (Space and Culture), and Scandals of Horror (Imaginations).

Elena Siemens est professeure agrégée dans le département des langues moderne et d'études culturelles de l'Université de l'Alberta. Elle est auteure de Theatre in Passing: A Moscow Photo-Diary (Intellect 2011), et coéditrice d'un dossier à paraître : The Dark Spectacle: Landscapes of Devastation in Film and Photography (Space and Culture), et Scandals of Horror (Imaginations).

Copyright Elena Siemens. This article is licensed under a Creative Commons 3.0 License although certain works referenced herein may be separately licensed, or the author has exercised their right to fair dealing under the Canadian Copyright Act. 


\section{BEAUTIFUL JUNKIES IMAGES OF DEGRADATION IN Requiem for a Dream

In Darren Aronofsky's 2000 film, Requiem for a Dream, based on Hubert Selby Jr.'s 1978 novel, he depicts extreme close-up images of heroin as it cooks, boils, enters a vein, and then passes into the body at the cellular level. The cells sizzle as heroin numbs them. The close-ups and sizzling sounds repeat themselves more and more frequently as our four main characters disintegrate through the process of becoming junkies. These images and others provide vivid, horrific, and exquisite visual renderings of the addiction process, while simultaneously providing stark evidence of heroin's take-over of the body, mind, and ethical capabilities. The images of heroin's allencompassing control of the body at its foundational level do not glorify heroin's power in Aronofsky's film; these images serve as documents of pure horror. The degradation is devastating, thorough, real, and scarring. Aronofsky describes his film as a monster movie, a modern horror film. And, it is not the type of film in which redemption occurs. The stark and individual solitude of each character at the end of the film cannot be easily penetrated by sobriety or love anytime in the foreseeable future.
Dans son film, Requiem for a Dream en 2000, unfilm basésurun roman deHubert Selby Jr. de 1978, Darren Aronofsky a montré, en très gros plan, des images d'héroïne cuisant et bouillant, puis entrant dans les veines et progressant dans le corps au niveau cellulaire. Les cellules grésillent à cause de l'héroïne qui les engourdit. Ce processus se répète de plus en plus souvent suivant le processus de désintégration des quatre personnages principaux qui deviennent des junkies. Ces images fournissent un récit visuel vif, raffiné mais terrifiant, de la dépendance, et démontrent la conquête du corps, de l'esprit et des capacités éthiques par l'héroïne. Ces images agissent comme preuves que l'horreur pure existe. La dégradation est dévastatrice, profonde, réelle, et elle laisse des traces. Aronofsky décrit son film comme un "monster movie ", un film d'horreur moderne dans lequel il n'y a pas de rédemption. La solitude extrême de chaque personnage à la fin du film ne sera pas facilement vaincue ni par sobriété, ni par l'amour. 
"Let's push-off," says Harry to Marion, as they sit on a rocky point off Coney Island extending into the Atlantic Ocean, smiling at each other with love; the sun shines radiantly, and the ocean gently caresses the rocks. No one participating in a walk along this vast landscape would take these characters to be junkies. They are beautiful; the landscape is beautiful; and, their love is beautiful. But this romantic and idyllic narrative will soon be interrupted. They will indeed "push-off," and forever disturb this fragile love story.

In Darren Aronofsky's 2000 film, Requiem for a Dream, based on Hubert Selby Jr's 1978 novel, the director depicts extreme close-up images of heroin as it cooks, boils, clouds a syringe, enters a vein, and then passes into the human bloodstream. The close-ups, sizzling and hissing sounds, pulses of threatening violin strings, and breathy intakes of shocked air, repeat themselves as the three characters invested in heroin Harry Goldfarb, Marion Silver, and Tyrone C. Love-- disintegrate through the process of becoming entranced and entrapped by the drug. These images and others provide vivid, horrific, and exquisite visual renderings of the addiction process, while simultaneously providing stark evidence of heroin's take-over of the body, mind, and ethical capabilities. Darren Aronofsky renders a euphoric expanse of narcotic space in Requiem for a Dream, ugly in its real-world horror, yet beautiful in its cinematic integrity.
Requiem for a Dream depicts twelve "street high" interruptions to the narrative flow of the film. These street highs include snorting and fixing heroin as well as smoking marijuana. The film also depicts the so-called licit highs of Sara Goldfarb from her addiction to diet pills, but this paper focuses on the street highs, the interruptions to life that move Harry, Tyrone, and Marion through metaphoric confrontations with their own demons, and that ultimately transform from interludes in life to the primary focus of their lives. By the end of the film, the three Requiem characters addicted to street highs will have transformed from activewalking, talking, loving, and scheming-beings to limp and vulnerable forms of flesh in fetal positions.

The first street high of the film occurs in chapter 3, entitled, "Dreams." Shot in extreme close-up and hip-hop montage style, the sequence flows so quickly that the images and sounds are barely distinguishable one from another. Hip-hop montage encompasses a compilation of numerous jolting devices in filmmaking: quick motion stops, intrusions of disassociated sounds, fast edits, floating dolly shots, distorted lenses, and extreme close-ups (Bianco 388). Aronofsky's hip-hop montages deliberately defy plot-driven narrative and offer instead a world outside of narrative progression. Scholar Paul Eisenstein explains:

If drug use [in Requiem] is rooted in repetition (captured formally by the hip-hop montage sequences used 
to present its use), the dream of a more idyllic future at least carries the (seeming) promise of narrative and of progress. (7)

The hip-hop montage utilizes sharply edited, extremely close-up, images that when nestled next to one another cause the eye to create a visual narration. When hip-hop montage is utilized, the viewer is not passively receiving the narrative. Instead, the viewer is bombarded visually and has to keep track of sets of images in order to construct fragments of a story.

In Requiem, the interruptions to narrative begin with Harry's first high of the film. He issues a soft, short utterance, "ahhh," and then we quickly see a magnified image of liquefied heroin heating, flame from a lighter, bubbles gurgling, edges of a bottle-cap holding an expanding cushion of cotton, the syringe, a pupil pinpointing, and the same pupil dilating, all ending with the repeated breathtaking, "ahhh.." Aronofsky creates this sequence by a combination of visual and sound effects that can only occur in film. The images are striking and beautiful, unique in content to the tragedy of heroin use, unique in form to the art of filmmaking. Some scholars critique the interruptive street high images as having become stereotypes of addiction in film, complete with their own uniform "ritual" (Lensing 2). But such critiques discuss these images as mere aspects of plot that "participate to a greater or lesser degree in what Jonathan White has called 'the Addiction Narrative,' in which the protagonist 'falls' into poverty and desperation as a result of addiction" (Lensing 2). Aronofsky, however, is up to something much more gripping with his up-close depictions of heroin use and his interruptive structure. Through the use of special cinematic effects that lay bare the technology inherit in moviemaking such as extreme-close-ups of needles penetrating skin; invasive, dissonant, and pulsating music by the Kronos Quartet; and, hip-hop montage that choreographs images of heroin use, Aronofsky asks us to submit to and reconsider the use of heroin from the close-up viewpoint of the user. He asks us to get close to the drug-use ritual and to try to empathize with how a user may become seduced by this powerful drug. By doing so, he is luring viewers into an age-old aesthetic argument regarding the history and philosophy of whether ugliness or horror can be presented as beautiful in art.

To prepare for the creation of his film, Aronofsky and his director of photography, Mattie Libatique, viewed Goya's paintings from the $18^{\text {th }}$ century, especially his huge early murals. They were both taken with the idea that the same man could paint joyous images of spring and summer and then later in life after his deafness, paint Saturn devouring his child. This artistic descent into unimaginable hell left an imagistic impression on Aronofsky that he wanted to relay in Requiem:

A big influence was Goya. Have you ever been to The Prado [Museum], in Madrid? It's a really amazing 
experience, because you walk around upstairs and you see all of Goya's early paintings, these huge murals. And they're actually named after the seasons, which is kind of weird, too, just the way our film is. [Requiem is broken up into different "Acts": "Summer," "Fall," and "Winter."] Goya would have this huge mural, about the size of a conference room wall, called "Summer," and there'd be people playing in a field and on pogo sticks. And then he has "Fall," and then "Winter." And everyone's happy and it's just lovely. And then, when he went deaf in his later years, he lived alone and he made these paintings called the "Black Paintings" on these walls. And have you ever seen his painting of Saturn devouring his child? That was one of them. That sort of descent, of the experience of walking around the Prado, was a big influence for me and my director of photography. The way Goya's career evolved is how we wanted our film to evolve. (Marano 3)

In Requiem, the street high interruptions in the narrative of his film are deliberately both menacing and beautiful, much like the image of a magnificent fire that is both gorgeous and threatening as it devours a landscape. But the power of these dazzling interludes only serves to forge an empathic understanding in viewers regarding the seductive qualities of heroin and the way in which heroin casts ruin upon the lives of the characters in the film.
The sheer repetition of drug preparation events as the characters become more and more addicted to heroin assure that the unsettling and seductive images do not condone nor draw attention away from the ruin of these characters' lives. Viewers become habituated to the images, and they permit viewers to understand, empathize, and experience the powerlessness of those who succumb to heroin addiction. The images of heroin's all-encompassing control of the body at its foundational level do not glorify heroin's power in Aronofsky's film; these images serve rather as sequences of horrific beauty. In chapter 7's "Juice," we watch Marion viewing her partially naked body in the mirror. She is trying to "see" herself, to see through the beauty of her body to the junkie she is becoming. Marion sees what is beautiful about herself, but she also knows, as we do, that she is taking this body down a very ugly road. She lingers over the image as many viewers have lingered over the standardly beautiful images of the female form in art, and then suddenly we see the montage and hear the special sound effects: her ripping the bindle, the breathtaking "ahhh," striking piano keys, the face of President George Washington, a rolled up dollar bill, an eerie clown giggle, the line of heroin, the sound of snorting, pinpointing pupils, dilating pupils, and finally the last "ahhh." Once again, Requiem depicts images of beauty-female bodies and filmic special effects-as paradoxical revelations about the ugliness of heroin use. The beautifying aspects are those cinematic techniques described by 
Jamie Skye Bianco in her essay "Techno Cinema:" aspects that "experiment with matter in non-human durations and extensions" (380). In Requiem, the heroin preparation occurs in dimensions that fill the screen; these dimensions are larger than the lives the heroin is about to affect; the viewer cannot even see the human figures due to the size of the drug preparation images. Time is not being kept in a recognized human dimension; time has switched to a narcotic-cinematic dimension. The drug is everything we can see; it is vast; it both interrupts and seems to exist outside of plot; it is horrifyingly indifferent to character. Heroin preparation becomes landscape, becomes all there is.

In his 2007 illustrative text, On Ugliness, scholar Umberto Eco delineates and depicts the historic tensions in art between the role of ugliness and compulsion toward representing only the beautiful. Eco reminds us that Thomas Aquinas thought beauty was the "result not only of due proportion, brightness or clarity but also of integrity - hence an object ... must have all the characteristics that its form has imposed upon the material" (Eco 15). In On Ugliness, Eco also highlights the longstanding role that Aristotle has played in determining the beautiful in art; he writes, Aristotle "sanctioned a principle that was to remain universally accepted over the centuries, namely that it is possible to make beautiful imitations of ugly things" (Eco 30). Further on in the text, Eco draws attention to Schiller's late $18^{\text {th }}$ century work, On Tragic Art (1792), in which Schiller observed that "it is a general phenomenon of our nature that sad, terrible, even horrific things are irresistibly attractive to us; and that scenes of suffering and terror repel and attract us with equal power" (Eco 282). In relationship to this history of the role of ugliness in art, Requiem for a Dream's particular representations of ugliness as beauty are multifold.

In order to maintain the integrity suggested by Thomas Aquinas, Aronofsky has to forfeit the preservation of viewer innocence. His film is not polite with its special effects; it doesn't fade to black when the characters pushoff in order to preserve viewer naiveté about heroin rituals. Instead, Aronofsky intensifies the truth of the matter through the technical aspects of its hiphop montage which delivers cinematic integrity to depiction of multiple forms of street drug use, particularly fixing, snorting, and toking. David Ng, a film reviewer, likens the film's representation of addiction to an El Greco painting in which "... grotesque forms approach something close to sainthood" ( $\mathrm{Ng} 10)$. In chapter 10, entitled "Dynamite," we witness Harry smoking weed. Through extreme close-up and fastpaced montage, Harry rolls marijuana in papers, licks the papers with an extreme close-up of the tongue, and fades behind a final swirl of smoke. And yet again, when a another interruptive montage occurs in the same chapter, Aronosfsky bombards the viewer with a split screen that flaunts dual sets of extreme close-ups, dual montages and 
sound effects of both Harry and Tyrone fixing heroin: Two hands ripping bindles, two breathtaking "ahhhs," two bottle caps holding heroin, a cigarette lighter, cottons, syringes, tying off, injecting, heroin entering, pinpointing pupils, dilating pupils, and a different finalizing "ahhh"-a sound of relief rather than the previous joy or expectation. The split screen amplifies the cinematic beauty of these scenes by creating a set of synchronized rituals flowing together in harmony. But, the culminating "ahhhs" of this joint high are not the same as the previous onesthese sound more like utterances of relief rather than the former utterances of awe. As the characters' bodies grow more tolerant of the drug, the highs change; they are no longer dreamlike, but rather, they have become like dynamite, waiting to explode the lives of these three characters.

Like Aristotle, Darren Aronofsky believes that it is possible to make an ugly thing beautiful in its representation. Not only does Requiem show the preparation and initial impact of heroin on the body in formal detail, its use of extreme close-up eradicates viewer judgment of the overall act and serves to enlarge, clarify, and beautify each element of the preparation process. The images themselves- the flowing liquids, the expanding cottons, the glowing fires, the pinpointing and dilating eye pupils-become precise artifacts displayed on the screen as in a gallery of drug preparation paraphernalia, procedures, and effects. These artifacts meticulously unpack and chronicle the exquisite fastidiousness of the heroin ritual, thereby delivering a curatorial majesty to its representation. In this film, Aronofsky designs a narcotic landscape replete with its own set of defining objects of art and its own particular form of representation.

In terms of Schiller's $18^{\text {th }}$ century understanding of horror, art, and beauty, as both seductive and tragic, Requiem is uncomfortable to watch and unforgettable for viewers precisely because its narrative portrays a set of tragic situations brought on by drug use and addiction. But the interruptive scenes are so powerfully depicted, and the actors portraying the characters being ravaged by drugs are so perfectly cast for their cinematic beauty (Jared Leto, Jennifer Connelly, and Marlon Wayans), that viewers cannot help but be lured into the monstrousness of the situations. Requiem deliberately encourages viewers to associate the beauty of these characters with the harrowing act of drug usage.

As the plot of Requiem begins to drive home the relationship among beauty, money, violence, and the junkie's life, the street high rituals too change just a bit. In chapter 13 , aptly entitled " $\$$," fast-moving close-ups again capture Marion ripping open the bindle, stirring with pestle and mortar, the rolled dollar bill, and then as she sets out two straight line of powdered heroin, the sounds of two gun shots accompany the laying-down of each line. We then see the lines hanging upside down from the table, and again, the images replay the 
drug flowing through the bloodstream, a pinpointing pupil, and a dilating pupil. Clearly, a threat of the violence to come is now included in the ritual. Aronofsky wants tensions between the beautiful and the damned, seduction and repulsion, dignity and disgust to increase gradually and to mark the visual and aural landscape of his film.

Aronofsky's film suggests that the $21^{\text {st }}$ century American social landscape is the product of a three-hundred year lie about the American Dream, particularly regarding who has access to it. Requiem for a Dream takes us far away from the original 1930 Motion Picture Production Code which ostensibly protected viewers from witnessing many of the horrors that might deter them from achieving their own American Dream. The Code clearly stated that "illegal drug traffic must never be presented," and in 1946 the revised provision read, "... illegal drug traffic must not be portrayed in such a way as to stimulate curiosity concerning the use of, or traffic in, such drugs; nor shall scenes be approved which show the use of illegal drugs, or their effects, in detail" (Simmons $47 \mathrm{n}$ ). However, Requiem for a Dream decidedly begins the $21^{\text {st }}$ century with a new code of ethics about drug depiction and a new definition of cinematic beauty. In chapter 15, "Sweet Alice," the sudden close-ups reveal Tyrone making a blunt. He tears open a cigar, removes the insides, stuffs the cigar skin with marijuana, licks the blunt closed, seals it, lights it with a lighter spark of fire, smokes it, and precisely closes the baggie. Tyrone is a business partner in the sale of heroin, but he only succumbs to the drug once in the film; Tyrone's drug of choice is weed. His American Dream in Requiem is to beat the street lifestyle to which many of his AfricanAmerican friends and associates have capitulated. He frequently thinks about his mother's wish for him to escape street life and to avoid prison, and he often ponders her photograph as a way of trying to turn his life around. But, Aronofsky decidedly presents Tyrone, Harry, and Marion as three different ordinary people for whom the American Dream seems so distant that the only possibility for achieving it is to engage in drug-trafficking and the selling of their own integrity to attain it. The impact--economically, psychologically, and emotionally-- of believing that the American Dream can be so attainedis a profound daily devastation that threatens to overtake ordinary people across generational lines, (Sara Goldfarb suffers from an addiction to diet pills that she believes will render her a young, beautiful, desirable American, once again) racial lines, and gender lines. The only beauty left in such a naïve and vulnerable landscape is the beauty of a poignant moment: the moment of love, the moment of the drug fix, or the moment of youth.

In chapter 16, "King's Neptune," the scene in which Harry suggests from the rocky point off Coney Island that he and Marion "push-off," Aronosfsky again splits the screen, and a dual montage emerges; one side depicts Marion snorting heroin, and the other 
depicts Harry fixing. In this scene, two bindles are opened; heroin is stirred on one side of the screen, while it is cooked on the other. She makes her lines, and he works his syringe, then his pupil pinpoints, her pupil pinpoints, his eye dilates, and her eye dilates, and heroin flows through the bloodstream. These images are striking, and, as viewers, we have become both used to their repetitiveness and intrigued by the display of unique images embedded in each ritual. The art and beauty of these devastating rituals is that they are not deadeningly the same; sometimes the order of the images is different, and sometimes new images or sounds occur in the ritual. Viewers begin to search out the newness in these routines as if this minimalist pursuit of something unique might actually resolve the horror of the characters' situations. Yet none of these moments of visual beauty is sustainable; they are mere narrative interruptions in Aronofsky's film, interruptions that horrifically alter the courses of three young lives.

Requiem for a Dream, like all horror films, revels in its special effects. Wellfaceted portrayals of the horror film's monster serve both to reveal the details of its physical and psychological dreadfulness and to make familiar the actual vulnerabilities associated with the monster's plight. In Requiem, the demon, heroin, like all monsters, can't help being monstrous. Heroin manifests its most atrocious features when it is perversely handled by humans. In chapter 17, ironically entitled, "Hope," the typical breathtaking "ahhh" of the previous rituals is much less apparent. As the addiction begins to overwhelm his body and his mind, Harry is less awestruck by the drug's initial rush through the bloodstream, than he is relieved to have supplied his need for the drug. He has become dependent on the monster. In chapter 18, "Fall Reprise," again Marion and Harry push off together. We view the split screen montages of her snorting routine and his fixing routine while dissonant and irritating strikes of violin strings accompany this particular high. The visual and aural intensity of the film has increased while Harry's and Marion's relationship to one another has become more and more disharmonic. Sadly, they are each more in need of the monster than they are of each other's love.

In order to attain more money for their drug habit, Harry asks Marion to have sex with her former therapist for money. At this moment, they both realize that their relationship has become something they are willing to barter and willing to traffic in order to attain heroin. The degraded narcotic space in which they exist supports only a connection to heroin, not a connection to each other's selves or dreams. While Marion is out of the apartment having sex with her therapist for money, Harry prepares a fix to soothe himself. Chapter 22, appropriately named "Apart," reveals a vivid tableau of images and sounds: the "ahhh," the cotton soaking up the liquid, the bottle cap, the belt tying off an arm, a syringe penetrating through cotton, heroin drawn up in a syringe, syringe shooting in, drawing out, shooting in, pupils pinpointing, pupils dilating. The 
"technoscience" involved in designing these images delivers an extraordinary excess to the screen (Bianco 380), an excess that both imagistically describes the addictive nature of the drug and one that agitates and overwhelms the imagination of the viewer. This "technocinema" allows us to "sense and feel drugged in this explosion of intensive powers" (Bianco 388). Aronofsky uses these cinematic devices to delve into the repulsiveness of drug addiction in order to create the visual language of the film; this language draws viewers into the mind-numbing and distorted realities of the main characters.

To further our connections to the main characters, Aronofsky utilizes the Snorricam, a camera attached to the character which presents the world from the character's point of view. The shots ironically present a steady, sturdy character as he/she moves through evershaking compositions, which leaves the impression that the character is not part of his or her environment (Marano 1). In chapter 26, "Winter Reprise," Harry and Tyrone are in a car driving to Florida. Harry rolls up his sleeve to reveal a horrid injection site, a gangrenous, purple, and oozing abscess. Tyrone is repulsed and can't believe that Harry is going to shoot into the sore. But Harry tells Tyrone that by inserting directly into the site, his pain will be relieved; thus, Harry religiously begins the ritual: we witness the tying off, the bottle cap, water, the lighter, fire, bubbles, syringe drawing, syringe injecting straight into the discolored pustule, red whirl of blood, pinpointing pupil, dilating pupil, and at last, and a pained cry of "ahhh." At this late stage of heroin use, Harry no longer uses to experience euphoria, he uses to relieve the overall physical and psychological pain that heroin use causes him. Aronofsky offers this montage as the most exquisitely honest evidence of the power that art possesses to depict dark human experiences.

The final street high of the film occurs in chapter 31, "The Requiem." This high follows Marion's return to her apartment from an excessively degrading trip to see her drug dealer. Completely separated now from Harry and Tyrone, she has to attain heroin on her own. For women, the economy of the street is distinctly sexual. Instead of money, she has to barter her beauty and her body for the drug. Thus, Marion agrees to perform group sex with women for a room full of cheering men. The debilitating memories of this event include a vulnerably naked and sweaty sexual performance with a dildo that connected her to another woman. Her payment for this performance is heroin. Once back in her apartment, she immediately snorts heroin, not to experience elation, but to erase the images of self-degradation that haunt her. This time, Aronofsky provides a shortened montage ritual: a dropped splat of powdered heroin, a line of the drug, and a rolled dollar bill. We know the ritual. Nothing special occurs during this routine; by now, it's just an average high Marion can trust to suppress memories of an unspeakable and vile exchange. As Umberto Eco reminds us, ". . . art in various centuries 
insistently portrayed ugliness. Marginal as the voice of art may be, it attempted to remind us that, despite the optimism of certain metaphysicians, there is something implacably and sadly malign about this world" (436). Sadly, the individual solitude and degradation of each character at the end of Requiem for a Dream depict the malignity brought about by heroin use.

Aronofsky's beautiful junkies each abide alone in their own bleak and devastated piece of the plot; their journeys with heroin have transformed them physically, mentally, and socially. Harry's arm has been literally amputated due to gangrene; Marion's body and self-image have been desecrated by herself; and, Tyrone has become the incarcerated street bum his mother dreaded. These exquisitely-rendered causalities of heroin's plunder and the unerringly-crafted drug montages provide clear evidence that images of degradation, when represented with integrity, do emerge as sadly beautiful in art.

\section{Works Cited}

Aronofsky, Darren. Dir. Requiem for a Dream. (Artisan Entertainment 2000).

Bianco, Jamie Skye. "Techno-Cinema." Comparative Literature Studies. 41(3): 2004.

Eco, Umberto. Ed. On Ugliness. New York: Rizzoli International Publications, 2007.

Eisenstein, Paul. "Devouring Holes: Darren Aronofsky's Requiem for a Dream and the Tectonics of Psychoanalysis." International Journal of Zizek Studies. 1(3): 2008. 1-23.

Lensing, Dennis. "Pariah Among Pariahs:
Images of the IV Drug User in the Context of AIDSs." Americana: The Journal of American Popular Culture 1900 to Present. 1(2): Spring 2002. Cited from: http://www. americanpopularculture.com/journal/articles/ fall_2002/lensing.htm

Marano, Michael. "Before Tackling Batman, Darren Aronofsky Has a Dream." Cited from http://aronofsky.tripod.com/interview13. html. July 30, 2010. (1-4).

Ng, David. "Requiem for a Dream." Cited from

http://www.imagesjournal.com/issue09/ reviews/requiem/ July 30, 2010. (1-5).

Selby, Hubert. Jr. Requiem for a Dream. New York: Thunder's Mouth Press, 1978.

Simmons, Jerold. "Challenging the Production Code: The Man with the Golden Arm.

Journal of Popular Film and Television. 33(1): Spring 2005. 39-48.

Dr. Renee R. Curry is Professor of Literature and former Dean of the College of Arts, Humanities, and Social Sciences at California State University Monterey Bay. She has published numerous scholarly articles and books on literature and film throughout her twenty-three year career as a scholar. Most recently, she has been researching the films of directors, Darren Aronofsky and Woody Allen.

Dr. Renee R. Curry est professeur de littérature à l'Université d'État de Californie Monterey Bay où elle a occupé le poste de doyen de l'école des Beaux-Arts, les humanités et sciences sociales. Elle a publié plusieurs articles et livres sur la littérature et le cinéma pendant ses vingt-trois ans de carrière de chercheur. Ces derniers temps, ses recherches se sont orientées vers les réalisateurs Darren Aronofsky et Woody Allen.

Copyright Renee R. Curry. This article is licensed under a Creative Commons 3.0 License although certain works referenced herein may be separately licensed, or the author has exercised their right to fair dealing under the Canadian Copyright Act. 


\section{THE VALLEY OF THE SHADOW OF DEATH}

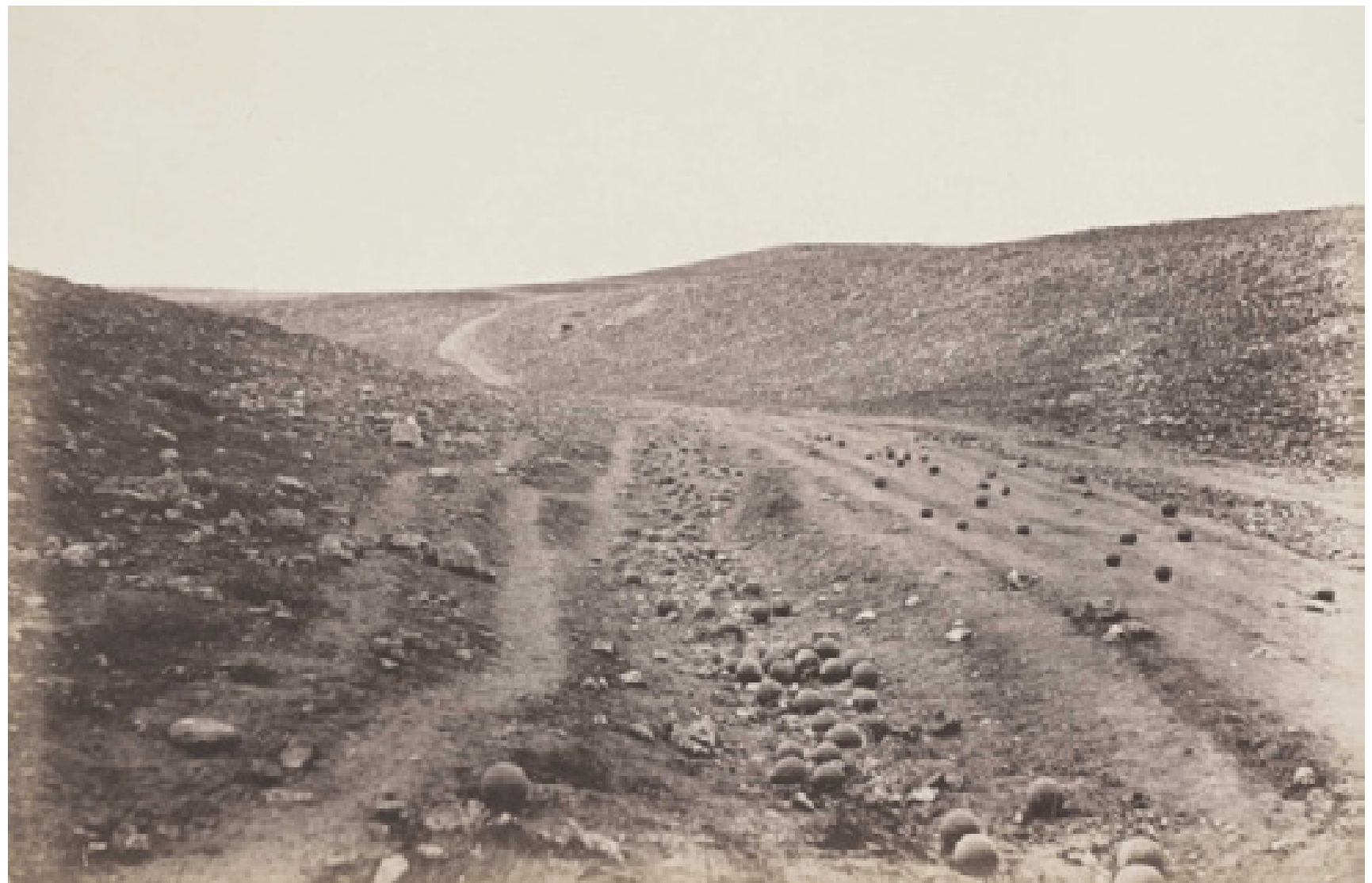

Fig. 1 Roger Fenton, The Valley of the Shadow of Death, Crimea, Russia 1855. Courtesy of MFA Houston.

"The Valley of the Shadow of Death" is a brief meditation on the refraction of sunsets over desolated landscapes, photography of war, and the viewer's relationship to the death of the sublime. The essay references the Museum of Fine Arts Houston exhibition "WAR/ PHOTOGRAPHY: Images of Armed Conflict and Its Aftermath" (2012-13) citing one of Roger Fenton's famous manipulated pictures from the Crimean war (1856) showing an empty landscape with cannonballs.
Cet article est une méditation brève autour de la réfraction des couchers de soleil sur des terres désolées, de la photographie de guerre, et le rapport spectatoriel à la mort du sublime. S'y trouve une référence à l'exposition " WAR/PHOTOGRAPHY: Images of Armed Conflict and Its Aftermath » (2012-2013), Museum of Fine Arts Huston) qui cite une des photographies manipulées célèbres de Roger Fenton sur la Guerre de Crimée (1856), illustrant un paysage vide avec des boulets de canons. 


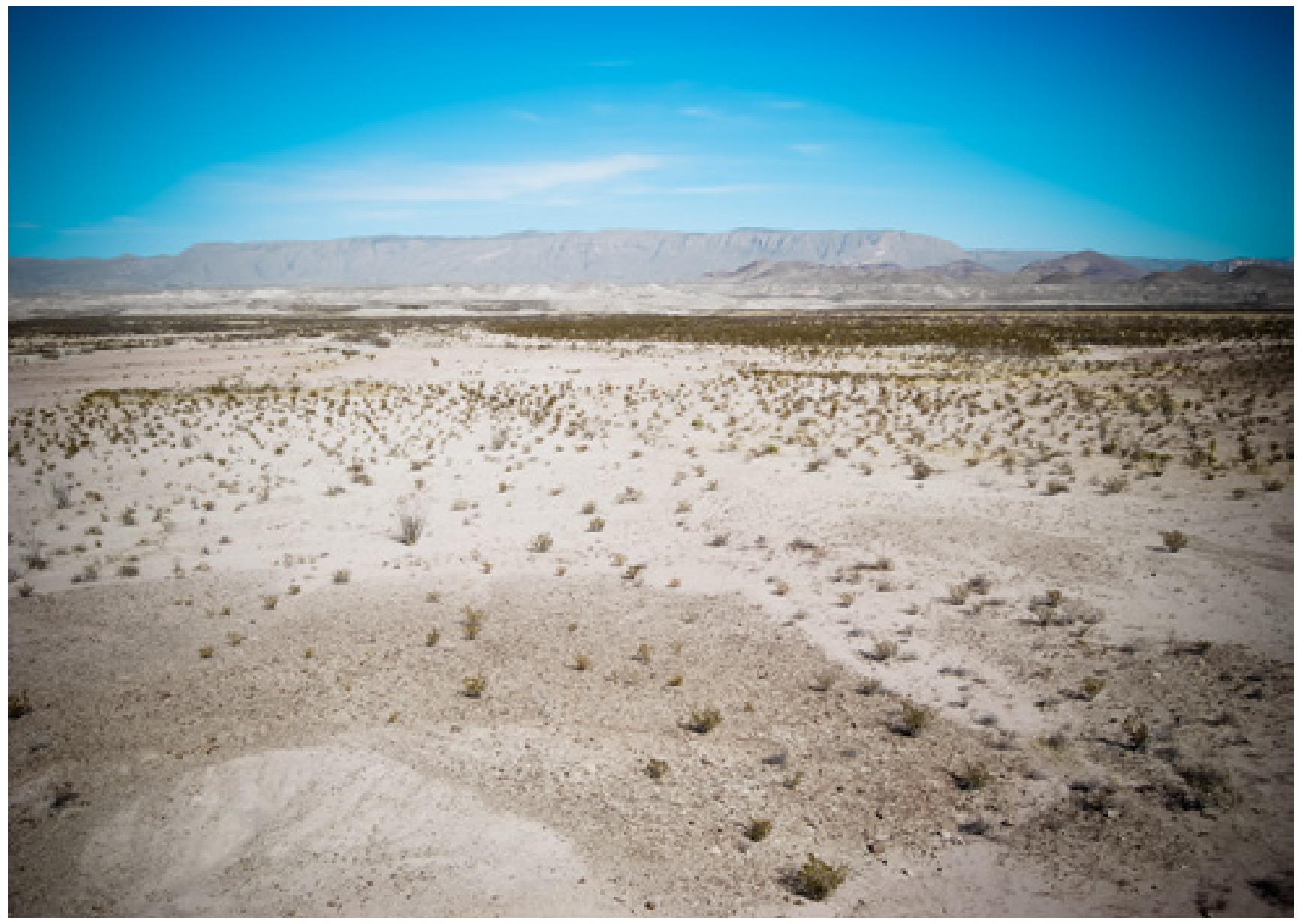

Fig. 2 The desert horizon beyond Croton Springs Trail in Big Bend, Texas. 2012

Returning to Houston after a week in the desert mountains of Big Bend (Texas), I struggle to remember the flashes of hallucination burnt into the retinae of my eyes. One night, patiently waiting for dusk, and standing atop a small hill, I stared for almost 45 minutes at the vast, endless sky as it turned kaleidoscopically from white yellow golden and red to blue pink and grey and saffron to black to the wordless and disenchanting realizations of a certain horror that is only enabled by what painters used to call the sublime. And yet we fail to recognize, perhaps, the physics underlying a setting of the sun in desert mountains, when tropospheric clouds enhance the scattering out and atmospheric refraction of twilight rays, when air molecules and particles affect colours and shapes that, in my hallucination, took on the form of a Kafkaesque wound -something dark red bleeding there in the distance, mocking my earlier view of the desert ground as I walked along the Croton Spring Trail fastening my eyes on tracks in the sand, dried mud, stones, petrified 
wood, remnant cairns, the desolate sedimented wash.

There too, in that forlorn wash, I sensed the temptation of the metaphysical, glimpsing ghosts of the dead who were not present, no skeleton bones and no trace of violence to be seen except in the inner howl remembered from Pasolini's Teorema, an aural violence I associate with war and its mythological waltzes with death and traumata unhealed. At the horizon of the desert, where volcanic formations rise up as if beckoning from the other side of life, the landscape stares back as a massive dead body.

The desert floor, now, for me in this trailing becomes the uncanny scene of animated film, alone I am naked, slowly trying to put my clothes back on, as if stepping into Ari Folman's Waltz with Bashir into voices that recount heading into an imaginary Beirut emerging from the sea of forgetting, the clouds scudding above a radioactive yellow land throbbing with the electric guitar sounds or machine gun fires that stopped long ago and yet are heard in the perennial soundtracks of our civilization of war.

My trail in Houston takes me to the Museum of Fine Arts and its current exhibition, WAR/PHOTOGRAPHY: Images of Armed Conflict and Its Aftermath, not suitable for children or the faint of heart, a gathering of nearly 500 objects including photographs, books, magazine, albums, and writings spanning six continents and almost two centuries of atrocities, evidences and fictions mingled with first-person accounts, hand-written thoughts and captions that seek to frame the brutally obvious or the obscure, the real and genuine and faked/staged and equally unspeakable reconnaissance captured, for example, in Roger Fenton's The Valley of the Shadow of Death, with or without cannonballs. Believing is not seeing the cannonballs or rocks or the desert but imagining yourself in the arrangement, naked putting your clothes back on if you can to hide the wounds that are caused by the relationship you have to Imaginative truth, to what you hear when you listen to the electric guitar, the voices or the machine gun fires, the exploding grenades under surveillance by our drones which capture the landscape from above, google-like, instantly tacitly implying the virtual - now setting a standard of authenticity and the sordid sublime to which the real is obliged to aspire if it is able to.

My closest friend, who accompanied me on the Croton Springs Trail, is a painter of landscapes, forever inspired by Caspar David Friedrich who knew little of the desert we just saw but looked to survey a rough sea and a gray, blank sky (The Monk at the Sea) in a process of reduction - this desert or valley of the shadow of death takes up most of the picture, as if emptiness and our desolation have become the only feasible Metaphysics, proper to mankind gazing blindly at the destruction it does not seem to fathom. 
Then what is a trail? Or if we think of the museum and its exhibition of the maimed and the raped and the killed - "unaccommodated" humans (dramatized in Samuel Beckett theatre of operations) - what is the renunciation required from us? The longevity of volcanic rock, quietly under the wounded skies, points the way for us.

Johannes Birringer is a choreographer and artistic director of AlienNation Co (www. aliennationcompany.com), and professor of performance technologies at Brunel University, London. He has directed numerous multimedia theatre, dance, and digital performances in Europe, the Americas, China and Australia; collaborated on site-specific installations, and exhibited work at film and video festivals. His interactive dance installation "Suna no Onna" was performed at the Laban Centre in 2007, and his mixed reality installation "UKIYO [Moveable Worlds]" premiered in 2009 before touring Eastern Europe in 2010. He founded a laboratory (http://interaktionslabor.de) providing artist residencies for collaborative interactive and screen-based performance projects, and co-directs the DAP-Lab (http:// www.brunel.ac.uk/dap), conducting research into sensor choreography, wearable computing and soft technologies. His current production, "for the time being", is a futurist dance opera.
Johannes Birringer est chorégraphe et directeur artistique de AlienNation Co. (www.aliennationcompany.com), ainsi que professeur de technologies de la performance à l'université Brunel à Londres. Il a mis en scène diverses performances de théâtre multimédia, de danse, et de représentation numérique en Europe, dans les Amériques, en Chine in situ, et exposé ses ouvres dans des festivals de film et de vidéo. Il a fait jouer son installation de danse interactive intitulée " Suna no Onna » au Laban Centre en 2007, puis, en 2009, son installation de réalité mixte "UKIYO [Moveable Worlds] » y a débuté avant d'entamer une tournée d'Europe de l'Est en 2010. Il a également fondé un atelier de projets de collaborations interactives et de représentation sur l'écran pour les artistes débutants (http://interaktionslabor.de). Actuellement, il codirige le DAP-Lab où se font des recherches en chorégraphie en capture de mouvement, et dans le développement de dispositifs électroniques intégrés aux vêtements. Sa plus récente mise-en-scène, intitulée "for the time being ", est un opéra de danse futuriste.

Copyright Johannes Birringer. This article is licensed under a Creative Commons 3.0 License although certain works referenced herein may be separately licensed, or the author has exercised their right to fair dealing under the Canadian Copyright Act. 


\section{A SURREALLANDSCAPE
OF DEVASTATION: AN ANALYSIS OF LEE MILLER'S GRIM GLORY PHOTOGRAPHS OF THE LONDON BLITZ}

LYNN HILDITCH

As surrealist war documents, Lee Miller's war photographs of the London Blitz, published in Ernestine Carter's Grim Glory: Pictures of Britain Under Fire (1941), effectively demonstrate what Susan Sontag referred to as "a beauty in ruins". Miller's Blitz photographs may be deemed aesthetically significant by considering her Surrealist background and by analyzing her images within the context of André Breton's theory of "convulsive beauty". Therefore, this essay aims to demonstrate how Miller's photographs not only depict the chaos and destruction of Britain during the Blitz, they also expose Surrealism's love of strange, evocative or humorous juxtapositions in the form of artistic visual representations of a temporary surreal landscape filled with fallen statues and broken typewriters.
En tant que documents de guerre surréalistes, les photographies du Blitz de Londres par Lee Miller démontrent ce que Susan Sontang a appelé " la beauté en ruines ». Ernestine Carter a publié ces photographies dans " Grim Glory: Pictures of Britain Under Fire » (1941). Elles ont une importance esthétique en vertu de leur contexte lié aux surréalistes, et dans la possibilité de les analyser en regard de la théorie d'André Breton sur " la beauté convulsive ». Cet article propose que les photographies de Miller non seulement représentent le désordre et la destruction de la Grande-Bretagne pendant le Blitz, mais qu'elles exposent aussi l'affection des surréalistes pour les juxtapositions étranges, évocateurs et humoristiques des représentations visuelles artistiques d'un paysage plein des statues effondrées et des machines à écrire cassée. 
Unreal City, Under the brown fog of a winter dawn, A crowd flowed under London Bridge, so many, I had not thought death had undone so many.

(Eliot 65)

Lee Miller's photographs of the London Blitz, including the twenty-two published in Ernestine Carter's Grim Glory: Pictures of Britain Under Fire (1941), effectively demonstrate what Susan Sontag describes as "a beauty in ruins" (Sontag 67). As a former student and muse of Man Ray during the late 1920s and early 1930s and a close associate of the Surrealists in Paris, Miller was able to effectively utilize her knowledge of Surrealism (and other art forms) to create an aestheticized reportage of a broken city ravished by war. Miller's war photographs may be analyzed within the context of André Breton's theory of "convulsive beauty"-his idea that an object or scene of devastation can be represented or analyzed as something beautiful by convulsing, or transforming, it into its apparent opposite. Therefore, Miller's war photographs not only depict the chaos and destruction of Britain during the Blitz, they also reveal Surrealism's love for quirky or evocative juxtapositions while creating an artistic visual representation of a temporary surreal landscape of fallen statues and broken typewriters. As Leo Mellor writes about these dualities, "The paradox of Miller's wartime reportage was announced in the title of her book of documentary photographs, Grim
Glory; that is to say, the coexistence of darkening mortality and ideal exaltation, like a Baroque conceit" (Mellor 75).

On the 4 September 1939, the day after war was declared in Britain, the Ministry of Information had been established with responsibility for news and press censorship, home publicity, and overseas promotion in Allied and neutral countries. Therefore, all non-Governmental publications were subject to strict censorship (The Art of War). Grim Glory was no exception and was primarily published as a propaganda effort aimed at the United States with the American title Bloody But Unbowed. However, the book proved surprisingly popular, achieving five printings in Britain alone. Editor Ernestine Carter recalls in her memoirs With Tongue in Chic (1974) that her and Miller "saw eye to eye on the oddities and awesome beauty, as well as the horrors of the Blitz" (56-57).

Like a Surrealist play on words, the British people had waited months for "the Phoney War,: "Bore War," "Funny War" or "Sitzkrieg," as the period from September 1939 to April 1940 became known, to the point that gas masks, black-outs, bomb shelters and evacuations had become part of their new-one might say "surreal"-way of life (Burke 200). The war, therefore, had forced London to assume a strange persona, the British people becoming the living subjects of a George Groszstyle painting. As Carolyn Burke writes: 
By October, Londoners were taking the increasingly surreal aspects of the Sitzkrieg in their stride. They covered windows with brown paper strips, installed "Anderson" shelters (named for the minister of home security) in the garden, if they had one, and, if not, prepared for the Blitz with the government-issue earplugs. Signs saying TO THE TRENCHES showed the way to dugouts in Hyde Park. By November, when the fog blanketed the city, flashlights were scarce; cigarettes gave a welcome source of light. People collided with one another; pedestrians found their way home by means of white lines on the curbs and gateposts (Burke 201).

Miller's contemporary at Vogue, Cecil Beaton, who was also working for the MoI photographing the London bomb damage for the publication History Under Fire (1941), referred to the chaotic nature of the Blitz in his diaries as a product of the "laws of blast" (Beaton 37) and it was the results of these "laws" that Miller chose to capture in her Grim Glory photographs. To a Surrealist photographer like Miller, capturing the destruction with her Rolleiflex camera was "not so much unfathomable as liberating"; a unique opportunity for an artist to create something aesthetically inspiring out of the devastation (Beaton 37). As Burke adds, "By wrecking some targets and sparing others, the bombs created wonders in the midst of chaos-as if Magritte or Dali had remade the landscape" (Burke 205). For example, in Miller's photographs, a broken window pane takes on the persona of the Gas, Light and Coke company trademark, Mr Therm (Carter, Grim Glory, plate 76); a bomb-ravaged building in Knightsbridge is transformed into the Venetian Bridge of Sighs (Carter, Grim Glory, plate 63); and in a London park a grounded barrage balloon becomes the giant "egg" of two extremely proudlooking geese (Carter, Grim Glory, plate 104). The creative potential of these scenes were endless. British Surrealist Julian Trevelyan noted in his 1957 autobiography Indigo Days that it "became absurd to compose Surrealist confections when high explosives could do it much better, and when German soldiers with Tommy-guns descended from the clouds on parachutes dressed as nuns. Life had caught up with Surrealism or Surrealism with life, and for a giddy moment we in England lived the irrational movement to its death" (Trevelyan 80).

Miller had already learnt from her mentor Man Ray that "every object and every person is beautiful, and that the artist's job is to find the moment, the angle, or the surroundings that reveal that beauty," no mater how horrendous it is (Miller 315).AndréBreton also noted in L'Amour Fou (Mad Love) (1937) how "convulsive beauty must respond to the deepest sense of the term...such beauty cannot appear except from the poignant feeling of the thing revealed, the integral certainty produced by the emergence of a solution, which, by its very nature, could not come to us along ordinary paths" (Breton 8). It was with this philosophy in mind that Miller 
began to photograph the Blitz. For example, beneath one of Miller's Blitz photographs depicting a bombed Nonconformist chapel taken in Camden Town in 1940, Carter has described in words what Miller has captured in visual form while replicating Trevelyan's thoughts. She writes:

If all that one saw was unrelieved tragedy, life would be unendurable in these beleaguered cities. Fortunately, the wanton behaviour of explosives and blast occasionally produces effects that are ironical, freakish, beautiful, and sometimes even funny, although the irony is grim and the humour threaded through with pathos (Carter, Grim Glory, 33).

With an element of dark humour, or bumour noir, the caption beneath the photograph reads, "1 Non-conformist chapel +1 bomb = Greek Temple" (Carter, Grim Glory, plate 74). Miller's reference to classical architecture seems to indicate that war can create time shifts by bringing the past into the future. All that remains of the building are the Ionic pillars standing defiant, reminiscent of those at the ancient Temple of Athena Nike in Athens. ${ }^{1}$ In another photograph of the blocked doorway of that same Non-conformist chapel, Miller has used irony and wit to suggest that the human congregation who once occupied the chapel has now been metamorphosed into a "congregation of bricks" (Penrose 103), ${ }^{2}$ thus indicating that even the House of God was not safe from the destructiveness of war. Here, Miller appears to be making an observation on the sacrilegious nature of war, while at the same time displaying an attitude that is essentially Dadaist in using images to express anger, disillusionment and the irrationality of war.

Several of Miller's Grim Glory photographs use random or chance objects, often placed or arranged by war, which reveal her awareness of the Surrealist practices of juxtaposition, the use of the objet trouvé (found object) and humour noir. As a result, these photographs combine an everyday aesthetic with a natural ability to search out the extraordinary in ordinary life. Indecent Exposure (1940), for example, focuses on two naked male mannequins wearing top hats and left standing at the side of the road with arms aloft as though hailing a taxi, or perhaps giving a sarcastic Nazi salute (Carter, Grim Glory, plate 77). One of the mannequins, who has no male genitalia, has a sign hung around his neck that reads, "Look what Adolf had done to me," suggesting that Miller is commenting on the humour of the British people who, amongst these dark times of the war, appear to have turned one small piece of the destruction into an amusing Surrealist scene. Similarly, Remington Silent (1940) depicts a mangled typewriter which, ironically, has been made "silent," by the bombings in London (Carter, Grim Glory, plate 72). Antony Penrose notes that the Remington Silent typewriter "was prized for being the quietest typewriter, but in the photograph it is tapping out an eloquent essay about the destruction of war," (Penrose, 102) just as Miller 
did in her photo-essays for Vogue magazine. Indeed, war correspondents, like Miller, used the typewriter as a weapon for attacking the enemy with words by describing and recording the war scene; and besides the typewriter, Miller had a second, arguably more powerful weapon for attacking with visual images-her camera.

\section{In Piano By Broadwood (1940),} Miller has photographed another objet trouvé-a musical instrument, once a symbol of affluence and high culture, which has been reduced to a piece of debris, yet another casualty of the Blitz (Carter, Grim Glory, plate 73). The piano displays the manufacturer's plate which indicates that it was produced by John Broadwood \& Sons, one of the oldest and most prestigious piano companies in the world, making instruments for some of the greatest musicians and composers such as Mozart, Haydn, Beethoven, and Liszt, and for royalty including the future Queen Elizabeth II. Burke describes the crushed object as "an eloquent testimony to a time when wailing sirens and droning dive-bombers composed London's nightly music" (206). This description of Miller's photograph is reminiscent of her second husband Roland Penrose's series of dark paintings including the 1940 work Black Music that depicted the noises of war as musical instruments. Perhaps Miller, like Penrose, saw the artistic significance of a musical instrument, whether captured in a photograph or a painting, as a way of making some sense out of the madness of conflict.
Even more poignant perhaps is Revenge on Culture (1940), ${ }^{3}$ a photograph depicting the statue of a female figure lying amongst the rubble (Carter, Grim Glory, plate 71). The figure, probably a Roman or Greek goddess, once a symbol of beauty, has been thrown from her pedestal and reduced to another chance object amongst the ruins, like the typewriter and the Broadwood piano. In this respect, the sculpture has become an object which has been transformed back into a piece of art (a photograph) via Miller's camera lens, thus symbolizing the rebirth of art, and perhaps the emancipation of women who adopted male roles during the war. It is also possible that Miller saw some similarities between herself and the statue-Miller had appeared as a statue brought back to life in Jean Cocteau's 1930 film Le Sang d'un Poète. In these three photographs-Remington Silent, Piano By Broadwood and Revenge on Culture-Miller has not only captured the oddities of war by photographing the objet trouvé; she has also produced a stark visual commentary on the death of culture (writing, music and art) as one of the consequences of war.

In conclusion, it becomes apparent when looking at photographs depicting the dark, nightmarish landscapes of urban destruction taken during the Blitz, including Miller's Grim Glory photographs, that there is a distinct lack of dead bodies on display. As Ian Walker explains, "In the great mass of photography of the Blitz, there are very few pictures of actual bodies, largely because of self-censorship. 
Rather buildings, statues, objects and mannequins become metaphors for the destruction wrought on real bodies" (156). Miller's photographs of the London Blitz, therefore, demonstrate an ability to transform, or "convulse," the real-the horror and devastation, the brutality of war-into the surreal, producing sensitive and at times humorous and witty portraits of war. As Nigel Henderson put it: "Surrealism was everywhere in a sense. Houses chopped by bombs while ladies were still sitting on the lavatory, the rest of the house gone but the wallpaper and fires still burning in the grate. Who can hold a candle to that kind of real life Surrealism?" (Hoffman and Read 12). While it might be argued that her later war photographs, particularly the harrowing images taken in 1945 at the concentration camps at Buchenwald and Dachau, ${ }^{4}$ were perhaps less informed by a Surrealist aesthetic due to Miller's humanistic need to document the scenes for future audiences, Penrose writes that even throughout Miller's earlier Grim Glory photographs:

[an] anger burns deep. But there is also a wit, as Lee shouts at the devil, in her photographs of the congregation of bricks tumbling out of the door of the wrecked Non-conformist chapel; the mannequins, naked but for their top hats, trying to hail a taxi in an empty street; and the two ineffably proud geese posing in front of a colossal silver egg, an adopted barrage balloon (Penrose 103)..
This quotation effectively sums up how Miller's photographs display an element of surprise often incited by a feeling of indignation conjured up by being a willing observer to the horrific consequences of World War Two, and how she used her Surrealist eye to produce unconventional photographic representations of the dark spectacle of war. 


\section{Works Cited}

The Art of War. "Learn about the Art: The Ministry of Information, INF series and INF 3." The National Archives. Accessed 10 March 2009. <www.nationalarchives.gov.uk/ theartofwar/inf3.htm>.

Beaton, Cecil. The Years Between: Diaries 1939-44. London: Weidenfeld and Nicolson, 1965. Print.

Breton, André. Mad Love (L'Amour Fou). Trans. Mary Ann Caws. Lincoln and London: University of Nebraska Press, 1988. Print.

Burke, Carolyn. Lee Miller. London and New York: Bloomsbury, 2005. Print.

Carter, Ernestine, ed. Grim Glory: Pictures of Britain Under Fire. London: Lund Humphries, 1941. Print.

---. With Tongue in Chic. London: Michael Joseph, 1974. Print.

Eliot, T.S. Collected Poems 1909-1962. London and Boston: Faber and Faber, 1963. Print.

Hoffman, Dave and Shirley Read. "Nigel Henderson." Camerawork, 11 (1978). Print.

MacKay, Marina, ed. The Cambridge Companion to the Literature of World War II. Cambridge: Cambridge University Press, 2009. Print.

Mellor, Leo. "War Journalism in English." In Marina MacKay, ed. The Cambridge Companion to the Literature of World War II. Cambridge: Cambridge University Press, 2009. 67-80. Print.

Miller, Lee. "I Worked with Man Ray", Lilliput, October 1941, vol. 9, no. 4. 315-324.

Penrose, Antony. The Lives of Lee Miller. New York: Holt, Rinehart and Winston, 1985. Print.

Pope-Hennessy, James and Cecil Beaton. History Under Fire. Mayfair, London: B.T. Batsford Ltd., 1941. Print.
Sontag, Susan. Regarding the Pain of Others. London: Penguin Books, 2004. Print.

Trevelyan, Julian. Indigo Days: Art and Memoirs of Julian Trevelyan. Aldershot: Scolar Press, 1996. Print.

Walker, Ian. So Exotic, So Homemade, Englishness and Documentary Photography. Manchester and New York: University of Manchester Press, 2007. Print.

\section{(Endnotes)}

1 Miller and Roland Penrose had travelled to Athens during July and August 1938, a trip that included visiting the islands of Delos and Mykonos, the theatre of Epidaurus in Peloponnese, and Delphi via the Thermopylae pass to the ancient monasteries of Meteora. This trip featured in Penrose's The Road is Wider than Long (1939; Walker 76).

2 Although the photograph of the blocked doorway was taken for Grim Glory, it was never included in the publication.

3 According to Antony Penrose, "Revenge on Culture" was reproduced numerous times during the war even appearing on the front cover of an Arabic newspaper (Penrose 104).

4 Miller was an accredited war photographer with the US Armed Forces and was with the 20th Armoured Division, the 42nd Infantry Division (also known as the Rainbow Company), and the 45th Infantry Division when they liberated the Dachau "death camp" on 29 April 1945. 
Lynn Hilditch has a Ph.D from the University of Liverpool and has lectured on various aspects of the visual arts and culture, including film history and theory, photography and modernism, photojournalism, and aesthetics. Her research interests include the depiction of war and destruction in art and photography, representations of the Holocaust in the visual arts, and the socio-historical representation of gender in twentieth-century popular culture. Lynn's doctoral research focused specifically on the Second World War photography of the American Surrealist and war correspondent Lee Miller and explored how Miller's war photographs may be analyzed as examples of 'surreal documentary.' Lynn has published work on various aspects of visual culture including book articles on Lee Miller's war photography, aesthetics and war, surrealism and photography, memory and memorialization, and 'fan culture' relating to the public persona of Audrey Hepburn. Lynn is a member of the Desmond Tutu Centre for War and Peace Studies at Liverpool Hope University.
Lynn Hilditch est titulaire d'un doctorat de l'Université de Liverpool. Elle a enseigné et donné des conférences sur les divers aspects des arts et de la culture visuels, y compris l'histoire et la théorie du cinéma, la photographie et le modernisme, le photojournalisme, et l'esthétique. Ses intérêts en matière de recherche sont les représentations de la guerre et de la destruction dans les arts plastiques et la photographie, ainsi que la représentation de l'Holocauste dans les arts visuels. De plus, elle s'intéresse à la représentation de sexes dans la culture du 20ème siècle. Dans sa thèse, elle s'est concentrée sur la photographie surréaliste de Lee Miller, une correspondante américaine pendant la Deuxième Guerre Mondiale, et particulièrement sur la possibilité d'analyser ces photographies en tant qu'exemples de " documentaires surréalistes ". Elle a publié sur divers aspects de la culture visuelle, y compris l'esthétique et la guerre, le surréalisme et la photographie, le souvenir et la commémoration, et la "fan culture » liée à l'image publique d'Audrey Hepburn. Elle est membre du Desmond Tutu Centre for War and Peace Studies à l'Université de Liverpool Hope.

Copyright Lynn Hilditch. This article is licensed under a Creative Commons 3.0 License although certain works referenced herein may be separately licensed, or the author has exercised their right to fair dealing under the Canadian Copyright Act. 


\section{This}

\section{HARD-BOILED TABLOID HAPPILY LOW-BROW} short

e s s a y

$\mathrm{d}$ iscusses

$\mathrm{A} \mathrm{m}$ e $\mathrm{r}$ i c a $\mathrm{n}$

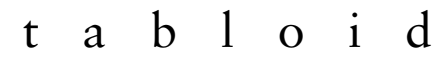
photography from the 1920s and 30s. The essay argues tabloid images of gangsters and murder scenes by Weegee and others are free from academic restraints, and, instead, they happily remain "low-brow."

There is an implicit critique of the American dream in works by Dashiell Hammett and Raymond Chandler, among others, a critique which also existed in the way the tabloid image of the gangster from the 1920 s and 30s became part of a complex urban folklore which was to a large degree at odds with the dominant values of the middleclass. Simon Bessie, in his 1936 book Jazz Journalism, notes how the tabloids were read by all social classes, but I would argue that the front-page images spoke differently to different social groups. Erin A. Smith, for example, in her book Hardboiled: Working-class Readers and Pulp Magazines, has examined how
BARBARA CHURCHILL working-

c 1 a s s

toward hard-

boiled fiction

differed from that

of the middle- to upper

classes, and the same can be said for tabloid photographs.

Tabloid readers of the 1920s and 30s were "poachers" (to use Michel de Certeau's term), who made their own meanings out of the photos of gangsters, in particular. Evasive readings often undermined the dominant privileged reading which was "Crime does not pay." It is always tricky to attempt to reconstruct the reading practices of marginal readers and viewers who did not have meaningful access to cultural production, and who have left limited traces. However, the fact that the figure of the gangster, along with those a t t it u d e s 
evasive readings, remain entrenched in the popular consciousness does provide some understanding of how the gangster was perceived in the early days of his legend-formation.

A recurring motif $\mathrm{I}$ encountered in scholarship on early-twentieth-century tabloid photography is the lament that tabloid photographs have been domesticated. To quote Penelope Pellizon and Nancy West, tabloid crime photographs have been "tamed, removed from [their] working-class tabloid context, and polished up as a cultural relic[s]" (Pellizzon and West 38). "The museum's interest in tabloid photographs," they say, is a classconscious way of enjoying the visions of crime now canonized by academia, and further disassociates those images from the decidedly lowbrow tabloids (Pellizzon and West 23). I asked myself if academia and museum culture really has the power to sever the images from their "low-brow" origins, since they have become so enmeshed in the popular visual repertoire. Is it not popular culture that has in a sense "canonized" them?

Geoffrey O'Brien, in his book Hardboiled America, notes, "Unlike the art that some critics may yearn for-a selfsufficient structure with clearly defined limits-these everyday creations are inseparable from life, are part of the definition of a particular moment they inhabit" (O'Brien 10). Tabloid newspapers, with their front-page crime photographs of murderers and dead gangsters, were "everyday creations" that defined a particular moment. Tabloid crime photography articulated a particularly pessimistic vision of American modernity, which O'Brien aptly describes as "a glittering hell ruled by money and violence" (O'Brien16).

The American tabloids first appeared in New York in 1919 with the publication of the Illustrated Daily News, followed soon after by The Daily Mirror and the Evening Graphic. The word "tabloid" referred to its compact size (almost half the size of the traditional paper) and its concise presentation of the news (Bessie 16). Unlike the more familiar supermarket tabloids of today (Nostradamous predicts...or Angelina Jolie's extra-marital affair-and the baby that is NOT Brad Pitt's), the early tabloids covered a wide range of material-from quick synopses of conventional news to crime and lurid scandal. The tabloid was the city paper par excellence, a commuter paper for working-class city dwellers. According to Bessie, "The contents of a page could be grasped at a glance and the whole paper could be handled with ease in the most crowded subway" (Bessie 83).

As Bessie notes, what made the tabloid especially distinct was its exploitation of the "graphic eloquence of the camera" (Bessie 99): "with the exception of a single headline and some small type, the front page was covered entirely with pictures" (Bessie 16). The front page was often a dark vision of American modernity, a "ceaseless manipulation of the ancient curiosities in Love, Death, Sin, Violence and Money" (Bessie 43- 
44). During the Jazz Age, detractors claimed the tabloids were a menace which would produce nothing but soiled and rotten minds (Bessie 213). This fear was rooted in a shift taking place from conventional journalism to photojournalism, a concern that images had the power to circumvent the word, a possibility that was gleefully trumpeted by the tabloids themselves: for example, the leading editorial in the first issue of the Daily News proclaimed, "The story that is told by a picture can be grasped instantly" (quoted in Bessie 84). No need for the concentration and effort required by elite viewing practices. This was an art of distraction, as Benjamin would put it.

During the 1920s and 30s, the crime rate in New York soared, and as tabloid newspapers increased their crime coverage, their sales rose accordingly. It was a time when "Crime paid," and "pictures of crime paid even more" (Hannigan 17). Bessie claims that embalmed in the arresting tabloid photographs "are the happenings and persons which comprise the folklore of [the] times, more so than conventional newspapers because from the start the tabloid identified itself completely with the common people" (Bessie 17). The story told in a photograph of a dead gangster, combined with the concerns and interests of the "common people", comprised a particular folklore of fatalism, a critique of the American Dream for those who had been largely denied access to that dream.
Arthur Fellig (also known as "Weegee the Famous," a tabloid photographer at this time), noted in his autobiography, that when it came to crime photos, "the bloodier and sexier the better. [The] millions of readers had to have their daily blood bath and sex potion to go with their breakfast" (Weegee 40). Commenting on his image "Gang Gets Revenge" (1939), Weegee writes: “a just-shot gangster, lying in the gutter, well dressed in his dark suit and pearl hat, hot off the griddle..." as Weegee put it (Weegee 37). Weegee points out how well-dressed the gangster is: as Erin Smith and David Ruth have noted, the gangster's apparel had powerful symbolic associations. The dream of American social mobility rested on visible consumer choices, and this particular "just-shot" gangster, Louis Cohen, dons polished shoes, an expensive suit, a silk scarf, and felt hat. He uncannily resembles a respectable businessman whose only error was to be caught alone and without the "protection" of a larger corporate bureaucracy. More importantly, Louis Cohen was able, through "dishonest" means, to shed class markers: leaving the ghetto and purging those ethnic traces that tended to restrict the social mobility of those who were "honest" (Ruth 63+). Louis Cohen is a morally ambiguous figure.

Tabloid photographers were trying less for artistic effect than for full coverage-a "meaty story" concentrated in one image. They needed to include as much information as possible in the frame. For example, 
in "Dropped on the Spot" by Willard, a New York gangster lies dead on $46^{\text {th }}$ and $10^{\text {th }}$. It's a synthesized image that readers could understand at a glance. No need for much explanatory copy, except to identify the gangster as David (the Beetle) Beadle, from "Hell's Kitchen". Circumstance has also lent the photograph a good dose of black humour: in front of The Spot Bar and Grill, "The Beetle" was placed "on the spot" (slang for "killed where he stood") and a street sign prompts us to be mindful of the Law: "Keep your sidewalk clean" and "Never sweep refuse into the street." Clive Scott terms such an image a "rebus image" in which the photographer "frames the shot to capture a street sign or writing within the image. The writing functions as ironic commentary on the represented actions, as if the world is captioning itself...." It is unavoidably simplistic because the image's meaning depends completely on the viewer's getting the encoded "pun" (quoted in P\&W 40).

But the viewer's interpretation of this pun depends on the viewer's subjectivity and position within the social hierarchy. The dominant or preferred reading is obvious: "Crime does not pay." David the Beetle Beadle is no better than litter, street refuse: he is a criminal. Seen from another point of view, his crime was that he contributed to the erosion between social, ethnic and criminal class distinctions. Folklorist Richard Meyer, when discussing the figure of the outlaw (which gangsters were), comments that the death of the outlaw reveals the "schizophrenic tension between optimism and fatalism which is so often a feature of those who perceive themselves as downtrodden" (115). Like Louis Cohen, David the Beetle Beadle had become a glamorous consumer, an optimistic, yet morally ambiguous, vision of the American Dream. His death, however, reinforced the idea that this dream was a hollow illusion: he was reduced to litter, to street refuse, despite his entrepreneurial aspirations.

These cheap, mean deaths were nightmarishly distended by the process of reproduction (Sante 9). Multiple copies of these front page photos appeared on newsstands, in shops, on the subway, a serial repetition that existed daily. According to Benjamin's “The Work of Art in the Age of Mechanical Reproduction," photography's power to shatter tradition rests on its reproducibility: a plurality of copies exists instead of an "original." The singular uniqueness of an original work of art, its presence, its "aura," facilitates its becoming part of museum culture. As Benjamin was quick to point out, even with photography's power to evade cult value, cult value does not give way without resistance (Benjamin 225). Benjamin acknowledged that even with an absolute emphasis on exhibition value, the artistic function may be recognized later (Benjamin 225). Such is the case with Weegee's photos.

The domestication of the tabloid photograph began with the photographer, and publicity hound, Weegee the Famous. While the 
photographs he took existed as a plurality of copies, with their shriveled aura, he compiled his New York photographs into a 1945 book titled Naked City, which became a best-seller. The disposable, tabloid photographs, destined for the trash bin, when placed in book form became the promise of durability. The book also offered the possibility of becoming "high art". Weegee's image "Corpse with Revolver" (1936) appears to be a "still life" of a corpse, revolver, and boater hat on blood-paddled pavement. Cult value requires a focus on the composition of the image, not the drama. According to Luc Sante's introduction to New York Noir: Crime Photos from the Daily News Archive, the "alchemical transformation of passing trivia and historically moot tragedy into art is a process accomplished by the viewer, who adds a decisive distance that confers upon the photographs a condition opposite to that of their origins. The viewer looks at obscure individuals and sees archetypes, looks at chaos and sees design..." (Sante 9).

The provocative power of the tabloid photograph, however, can not be divorced from a larger popular folklore. As Sante notes, it is the viewer who adds the "decisive distance", but only if the viewer exists in a bubble. The images of Dominick Didato, Lois Cohen and David Beadle, call to mind endless movies: from the 1931 film The Public Enemy, to The Godfather (1972) to The Untouchables (1987), to Goodfellas (1990), as well as the popular television show, The Sopranos. Some of these photographs have made their way into the 2007 graphic novel, Criminal. The fascination with images of the gangster from tabloid photography rests on the drama, the rise and fall of the urban outlaw. Such images were free of academic restraints when they were created, and despite attempts to polish up these visions of crime, they happily remain decidedly "low-brow". 


\section{Bibliography}

Benjamin, Walter. "The Work of Art in the Age of Mechanical Reproduction.” 1936. Trans.

Hannah Arendt. Illuminations. New York: Schocken Books, 1968. 217-251.

Bessie, Simon Michael. Jazz Journalism: The Story of the Tabloid Newspapers. 1938. New York: Russell \& Russell, 1969.

Fellig, Arthur (Weegee.). Weegee by Weegee: An Autobiography. New York: Ziff-Davis, 1961.

Hannigan, William. New York Noir: Crime Photos from the Daily News Archive. New York: Rizzoli, 1999.

Meyer, Richard E. "The Outlaw: A Distinctive American Folk Type." Journal of the

Folklore Institute 17(1980): 93-124.

O'Brien, Geoffrey. Hardboiled America: Lurid Paperbacks and the Masters of Noir. New York: Da Capo Press, 1997.

Pellizon, V. Penelope and Nancy M. West. "Good Stories' from the Mean Streets: Weegee and Hard-boiled Autobiography." The Yale Journal of Criticism (2004): 20-50.

Ruth, David E. Inventing the Public Enemy: The Gangster in American Culture, 19181934. Chicago: U of Chicago P, 1996.

Sante, Luc. Introduction. New York Noir: Crime Photos from the Daily News Archive. By William Hannigan. New York: Rizzoli, 1999. 7-13.

Smith, Erin A. Hard-Boiled: Working Class Readers and Pulp Magazines. Philadelphia:

Temple UP, 2000.
Barbra Churchill teaches in Comparative literature Program, University of Alberta. Her research interests include Popular Fiction $\&$ Culture (esp. the Popular Romance); Literature \& the Visual Arts (esp early 20th century modernist/avant garde).

Barbara Churchill enseigne dans le cadre du programme de littérature comparée à l'Université de l'Alberta. Ses intérêts de recherche incluent la fiction et la culture populaire (principalement les histoire d'amour populaires), la littérature et les arts visuels (principalement l'art moderniste/ avant-gardiste du début du 20ème siècle).

Copyright Barbra Churchill. This article is licensed under a Creative Commons 3.0 License although certain works referenced herein may be separately licensed, or the author has exercised their right to fair dealing under the Canadian Copyright Act.

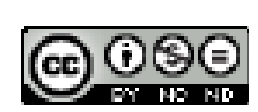




\title{
IN SEARCH OF AUTHENTICITY TIME AND SPACE IN RUSSIAN HORROR FILM
}

\author{
VOLHA ISAKAVA
}

The paper looks into recent Russian horror films, exploring how the genre conventions associated with Hollywood are transformed and upheld in Russian cinema. The paper argues that the use of space, particularly urban venues, in horror films establishes a sense of authenticity and marks otherwise derivative generic productions as uniquely Russian. The films examined are Night and Day Watch duology (2004, 2006), Trackman (2007) and Dead Daughters (2007); all are set in contemporary Moscow.
Cet article est une investigation des récents films d'horreur qui cherche montrer la façon selon laquelle les conventions hollywoodiennes ont été à la fois transformées et maintenues dans le cinéma russe. On y propose que l'emploi de l'espace (surtout les lieus urbains) dans les films d'horreur établit une authenticité et confère à productions autrement considérées génériques et non originale son caractère spécifiquement russes. Les films étudiés sont les deux "Night and Day Watch » $(2004,2006)$, "Trackman » (2007), et « Dead Daughters » (2007) : tous ont été tournés dans le Moscou contemporain. 
In this paper, I will look at the representations of time and space in recent Russian horror films, investigating the correlation between horror genre conventions, imported via Hollywood films, and what I see as an attempt to "modify" them to suit unique local sensibilities and create an authentic popular Russian product. The paper argues that one of the most significant aspects of understanding Russian horror is its dependency on generic conventions that are associated with Hollywood genres. The Russian cinema industry, like many other national film industries, is positioned vis-a-vis "Hollywood hegemony" (Shohat \& Stam 1994) in popular culture. It competes with Hollywood films at the box office, and must appeal to an audience whose tastes are shaped by Hollywood genres. At the same time, the domestic films need to differentiate themselves from Hollywood or, simply put, provide a reason why an average movie-goer should choose to watch a Russian horror film as opposed to a North American horror film. The replication of Hollywood genre tropes is, therefore, couched in a certain degree of reflexivity and self-awareness that complicates the effort to make a faithful copy of a Hollywood model. I argue that the effort to showcase this distinction manifests itself, among other things, through the engagement of time and space. Drawing on analyses of several recent horror productions Trackman, Dead Daughters (both from 2007) and the fantasy-horror duology Night and Day Watch (2004 and 2006) - this paper explores how these horror films re-imagine familiar cultural spaces and re-interpret recent Russian history in an attempt to "russify" the foreign genre formula. By focusing on the films' particular appropriation of the Soviet past and the nostalgia associated with it, I hope to demonstrate that the horror films, despite their seemingly derivative nature and low cultural status, showcase the ambivalence and complexity of the current cultural and political landscape in Russia, addressing issues of memory and identity, and engaging competing historical narratives.

The horror genre has a very limited presence in the history of Russian cinema. One example that stands out is the 1967 film Viy. The film is not strictly a horror film. It is an adaptation of a nineteenth-century short story by Nikolai Gogol that contains Gothic supernatural elements and is based on Ukrainian folklore. Being part of the Soviet state-controlled film industry, the film does not have many of the horror genre's usual attractions, such as excessive violence, shocking imagery, or sexuality. These elements, among other conventions of the genre, would obviously not pass the censors, and that fact very likely contributed to the absence of horror in the Soviet tradition in general. As Josephine Woll (2005) mentions, horror “...contradicts almost every major tenet of Marxist historical materialism, of Soviet doctrine, and of socialist realist dogma...” (344), making the genre an outcast of Soviet filmmaking. This situation changed as the Glasnost reforms of the late-1980s lifted many of the cinematic taboos of 
the Soviet film industry and allowed an unprecedented exposure to all things Western,including horror films.Included in the newly-accessible cinematic products were various B-list films, such as martial arts movies, crime thrillers, exploitation films and pornography, and horror films of all varieties (from cult classics like Nightmare on Elm Street to obscure grind-house productions). They became accessible to the Russian viewer chiefly via local "videosalons" and cable television networks that became widespread in the 1990s (Condee 2009). It is in the 1990s that we see the first Russian attempts at the horror genre. The Touch [Prikosnovenie] from 1992 dealt with the supernatural, providing some ingenious innovations, like the dead talking from beyond the grave through a train-station PA system in lieu of special effects. The Vampire [Upyr'] from 1997 was more of an action thriller, in which vampires were a thinly veiled allegory for the ubiquitous 1990s gangsters. The Snake Well [Zmeinyi istochnik], also from 1997, was the first Russian slasher horror. Rather mild in both the gore and teenage sexuality typical of the genre, but high on suspense and murder mystery, it is undoubtedly indebted to Hitchcock's Psycho.

Severe economic crisis during the 1990s facilitated the collapse of the previously state-sponsored and tightly controlled film industry, as it tried to navigate its way towards a market-based economy. The Russian film industry almost came to a halt, and the number of domestic productions decreased dramatically. ${ }^{1}$
Susan Larsen (2003) writes:

The reasons for the decline of the Russian film industry are by now well known: the collapse of centralized distribution networks; a flood of low-priced foreign imports into the cinema, television, and video markets; the dilapidated condition and outdated equipment of Soviet-era cinemas; widespread video piracy; the much-maligned "darkness" (chernukha) of so many contemporary films; and the economic crises that decimated government subsidies for the film industry and made cinema tickets a luxury for the few rather than entertainment for the masses (491).

Consequently, 1990s horror did not thrive due to budget problems, outdated technology inherited from Soviet times, and the absence of generic tradition and its target audience. The 1990s horror films, which were few to begin with, were forgotten and seem to have had little to no impact on the developmentofthecontemporary $(2000$ and onward) horror genre in Russia, which became increasingly exposed to and dependent on Hollywood horror models. Domestically produced horror still remains on the margins of the mainstream in Russia. And, indeed, to my knowledge, only about five or seven horror films were produced by Russian studios in the past five years. Similar to the Soviet era, when the horror genre was largely absent from the screen, but might resurface through elements of horror in the sci-fi genre, or in literary 
adaptation with folklore overtones, such as Viy, in contemporary Russian cinema several fantasy and sci-fi films employ the conventions of horror. The most prominent examples of such genrebending are the blockbusters Night and Day Watch from 2004 and 2006, respectively. In addition to mainstream horror, an avant-garde "necrorealism" film movement that experiments with horror conventions gained prominence after the fall of the Soviet Union. There are also several low-budget films by amateur directors that so far have not harnessed the success of The Blair Witch Project.

In this paper, I will look only at the mainstream productions that aim to position themselves as part of popular culture, a Russian take on what is seen in Russia as a typically Western (and mostly Hollywood) genre. My main field of inquiry lies in the domain of genre appropriation. I will examine films that consciously consider and sell themselves as horror, hoping to entertain and attract audiences and fill the horror niche in the Russian cinematic landscape. In contrast to the economically and socially turbulent 1990s, Russian national cinema has experienced a revival since the early 2000s as the economy has improved and audiences started showing interest in going to the movies again. Today, Russia has the fifth largest cinema market in the world with popular domestic films often dominating the box office, even if Hollywood productions still outpace and outsell Russian films (Beumers 2009). In the sphere of popular culture,
I think, Russian mainstream cinema faces a dilemma that is particularly acute in an unexplored genre like horror: how to produce a popular film with a national sensibility, or a film that maintains conventional genre thrills and has a specific appeal to a Russian audience. In short, how does one go about making a "Russian horror"?

The first part of the "Russian horror" equation is its "Russianness." It has been argued in scholarship that the "Russianness" of film could be intimately connected with the (re)vision of history as one of the primary concerns in contemporary Russian cinema. Susan Larsen (2003) writes that cinema's national appeal explores "what it means to be Russian.., engaged - more or less explicitly - with the relationship between contemporary Russian life and the cultural traditions of the Soviet and pre-revolutionary past" (493). The reconfiguration and reconstruction of history in an attempt to create a linear comprehensive narrative instead of a patchwork of fragments or series of ruptures is of particular importance. If we accept Paul Ricoeur's argument in Time and Narrative (1990) that understanding history is embedded in story-telling, one can see the importance of the negotiation of various historical narratives that compete with and counteract each other in post-Soviet space. Popular culture, and cinema in particular, is part of these negotiations. The Soviet narrative of history vilified the pre-revolutionary past and glorified the Soviet present. However, it was followed by the critical Glasnost 
narratives of the 1980s and 1990s, which exposed the Soviet vision of history as a monstrous lie, creating a traumatic rupture symbolically embedded in the collapse of the Soviet Union. It is often argued that the contemporary regime of "velvet restoration" (a designation coined by Lev Rubinshtein) headed by Vladimir Putin appeals to Soviet nostalgia, promoting the values of stability and nationalism embedded in the past, particularly the Soviet one (Lipovetsky 2004). Or, in other words, it aims at reconstructing the historic continuity and plausibility of the historic narrative, very likely with the political goal of ensuring the regime's preservation. While to present a political reading of Russian popular culture here is outside my scope, I am interested in how popular cinema engages these diverse narrativizations of history to create a product that appeals to the sense of national identity.

The second part of the "Russian horror" equation is undoubtedly "horror." Today's generation of Russian moviegoers has ideas about horror genre conventions that are attached almost exclusively to the Hollywood cinematic "lingua franca," to borrow David Bordwell's term (2006). Furthermore, while Soviet cinema had a strong tradition in comedy, satire, and drama, horror presents a prominent case of a "borrowed" genre and, therefore, a more explicit example of negotiations in Russian popular culture between national authenticity and generic complicity. I argue that the construction of space and history in mainstream horror both showcases the formulaic approach to genre and provides a unique engagement with history and identity that preoccupies Russian cinema as a national cinema today.

\section{Hollywood, Here We Come}

Most of the horror films I have seen consciously engage Hollywood genre formulas and are very aware of their foreignness, sometimes playfully appropriating this exoticism. When the Russian blockbuster fantasy duology Night and Day Watch quotes The Matrix, X-Men, Lord of the Rings and a legion of other Hollywood films, the exuberance of this gesture produces a certain pride in the hybridity of the moment - as if its "Russianness" is achieved through excessive and defiant "in-your-face" foreignness. Night Watch [Nochnoi dozor], directed by Timur Bekmambetov, released in 2004, became an instant hit in Russia and one of the most financially successful Russian films of recent years, surpassed only by its sequel, Day Watch [Dnevnoi dozor] in 2006. Both films belong to the fantasy genre with a strong streak of horror, telling the story of the "others" - a special race of super-humans that is immortal and lives on human blood. Some of them, however, are "good guys" and are called the "night watch," and some are "bad guys," called the "day watch." They each keep an eye on each other, so that no side abuses its power over humans. Night Watch narrates a father-and-son redemption story. In the end the near apocalypse is averted, 
the world is saved, and the protagonist finds both redemption and true love.

Despite the fact that the story is based on a series of best-selling Russian novels by Sergei Luk'ianenko, both films maintain a very distinct visual appeal based on fast-paced special effects and effective cinematic allusions. Night Watch, for example, explicitly alludes to the Matrix, fashioning the protagonist after Neo, and sporting a similar video-game style fast-pace editing and cinematography. Furthermore, the "others" of the two films possess superpowers, those unique gifts drawn from the comic book tradition of superheroes. They are also wizards, belonging to a fantastic and archaic world order, and decadent gothic urban vampires - all at the same time. The Watch movies seem to almost engage in a Socialist competition - the Russian blockbuster movie has to be bigger and better than Hollywood's. There is a sly sincerity to such an endeavour. On the one hand, the desire to appropriate Hollywood and make us aware of the well-known effects, images and stunts is a self-aggrandizing effort, presented as a continuous stream of visually aggressive sequences that barrage the viewer with allusions. On the other hand, an overwhelming level of quotations, with the occasional bit of irony and humour detaches the narrative from strict imitation, suggesting instead a playful appropriation. Thus, several references to Matrix transform into a humorous depiction of a Russian cultural comic trope - hang-over. The protagonist wears dark shades, not to emanate ultimate coolness as $\mathrm{Neo}$ does, but to conceal the effects of his heavy drinking. In short, sincerity and irony, allusion and its deconstruction, combine and arm the Watch films with a novelty and recognition that often catches the viewer by surprise.

In another recent horror film entitled Trackman [Putevoi obkhodchik] from 2007, directed by Igor Shavlak, the power of allusion provides a path for self-effacement in the film. Even in the posters and promotions, one can see that Trackman unambiguously points to the multitude of other horror films that employ the masked serial-killer trope (examples include Texas Chainsaw Massacre and Halloween). Similar poster strategies are present in the Watch franchise (see fig. 1) Trackman is especially close to George Mihalka's Canadian slasher film My Bloody Valentine (1981), which was recently remade. Just like Trackman, Valentine deals with a maniac from down below (miner in Valentine, subway/sewer monster in Trackman) wielding a pick axe, wearing a similar mask and depriving his victims of specific body parts. In addition to the masked killer horror films allusions, Trackman also starts with a children's song reminiscent of the Nightmare on Elm Street horror series. Trackman follows a gang of bank robbers who plot their misdeeds at McDonald's (a marker for Western pop culture) and then, after a botched robbery job, go into an abandoned part of the Moscow metro system with two female hostages. The hostages are pencil-skirt wearing banking assistants, a strong and compassionate blonde and 
a complaining brunette - just like in $M y$ Bloody Valentine. The blonde perishes in a shooting accident and is avenged by the Trackman, who develops an attachment to her similar to the famous storyline of King Kong. The brunette falls for the charming gang leader and the two escape after fighting off Trackman, a monstrous maniac, formerly a rescue worker at Chernobyl, who, for reasons unknown, collects the gouged eyes of his victims.

Similar to Day and Night Watch, Trackman validates itself as a horrorgenrefilm by emphasizing its simulacrum nature towards the Hollywood original in hopes of harnessing popular appeal. It is no exaggeration to suggest, as did Ella Shohat and Robert Stam in Unthinking Eurocentrism (1994), that Hollywood cinematic hegemony in the national cinema markets could be viewed from the point of view of imperialism and colonialism as sites of colonization and resistance. This perspective allows one to look at the Russian horror films as seeking validation through mimicry of the "better," Western model. This mimicry is not unproblematic. As Homi Bhabha famously suggested, the wish to mimic the colonial "better" model results in the "almost the same but not quite" bind for the colonized. Bhabha (1994) notes that mimicry "...in order to be effective... must continually produce its slippage, its excess, its difference" (86). I suggest that, while replicating horror models imported from Hollywood, Russian horror films could also be creating a site of "slippage" and difference that subverts the "colonial" conventional genre model and engages local discourse on identity, history and belonging.

Horror as the site of such difference and subversion should not surprise us, as the horror genre is historically known for channelling the subversive and the transgressive elements of cultural discourse through popular culture (see Robin Wood (1986), Adam Lowenstein (2005) and others). The horror genre has always been a bit of an enfant terrible of mainstream American cinema. Horror is often analyzed as a reflection of anxieties, repressed desires and traumatic ruptures of national consciousness or unconsciousness. Robin Wood (1986) in his analysis of 1970s horror films, states that horror experiments with intense graphic violence and shocking sexuality, while maintaining an "incoherent" narrative and unpolished, raw, low-budget look, as in The Texas Chainsaw Massacre. The transgressive discourse of horror in the 1970s exposes a cultural (namely capitalist, in Wood's opinion) veneer disguising the abyss of the politically and socially repressed, reconstructing the other as a monster and American life as hell or "...the sense of a civilization condemning itself, through its popular culture... and ambivalently celebrating the fact" (Wood 95). Horror, in other words, produces a certain excess and slippage that allows one to engage in cultural analysis beyond the graphic and exploitative elements of horror entertainment. Similarly, Russian horror films, by engaging Hollywood, also produce a certain excessive 
response, a surplus of meaning that reveals the difference and subversion of mimicry more than it explicitly intends to. I argue that the construction of time and space in horror films proves to be crucial in producing that difference.

\section{Russia, There We Stay}

The Russian horror genre is often contemporary, with recognizable urban landscapes that in many cases belong to Russia's capital, Moscow. Similar to the mainstream American horror genre that is often considered to target the adolescent male audience, Russian horror film could be described as oriented towards urban youth as well. Moscow becomes the space that exemplifies contemporary, youthful, urban Russia. The Night and Day Watch duology is one such example, making Moscow an effective generic counterpart of cinematic New York or London, with spectacular apocalypse included. Trackman takes place in abandoned Moscow subway tunnels. The film I would like to consider now, Dead Daughters [Mertvye docheri] from 2007, directed by Pavel Ruminov, eschews the common and easily identifiable venues in the capital and shifts the spatial focus to the Moscow suburbs. It is these familiar spaces, which are laden with cultural context and recognition that become a bridge between the generic mimicry and local sense of authenticity.

Dead Daughters is a J-horror [Japanese horror], Russian style. The derivative nature of the story is transparent and its transparency is playfully encouraged by the film. The film makes enthusiastic nods to Ringu (Hideo Nakata, Japan 1998), albeit in its American incarnation The Ring (Gore Verbinsky 2002). Similar to these films it builds its narrative around guilt, suspense and fate - staging a morality play of spiritual quest and a critique of the shallow young generation. A curse is set in motion by the last person who sees the victim of the vengeful ghosts of little girls killed by their own mother. By chance the curse falls on a group of five friends, young Muscovites with upper middleclass jobs and well-to-do lifestyles, and we watch them fall victims to the curse, until the "final girl" assumes the identity of the dead mother and rules over the naughty dead children. The visuals in the film aim to justify its art-house claim, widely discussed even before the release of the film in Russian press. They feature a lot of hand-held camera and long shots, often relying on light and colour contrasts. The "artiness" of the film, however, is not what I would like to focus on, but rather the spaces that the film uses and what these spaces represent in the context of Russian horror.

Dead Daughters is a pronounced urban horror and it does an excellent job in turning ubiquitous urban spots likecafes, basketball courts and movie theatres into uncanny spaces of supernatural danger. The device that turns a familiar space into a threatening one is especially successful in classic slasher films like Halloween or Nightmare on Elm Street, where the most intimate space, like a 
middle-class family home, becomes the site of deadly carnage. In the end the victims in Dead Daughters are also killed in familiar urban spaces - the children's park, one's own apartment, a basketball court in the suburbs. The film makes these spaces look generic by avoiding the obvious tourist highlights of Moscow, which is at once identifiable as the real city that the protagonists live in, but is presented as if it could be any city. The film's spaces are saturated with the everyday, showcasing a cafe or a parking lot rather than spaces of cultural prominence in Moscow that have a long cinematic tradition. For example, every time the heroes reconvene to discuss their predicament they meet in various cheap diners where they try to formulate a plan, sometimes observed by the camera as if from the outside like the "nighthawks" from Edward Hopper's painting. The film successfully conveys their increased sense of isolation and vulnerability when the camera allies itself with the invisible ghosts. The characters are not only watched by the vengeful ghosts but also can no longer integrate fully into the daily activities of the city, being constantly under the camera's gaze, isolated and voyeuristically observed in their predicament.

The images that stubbornly reappear in the film and that are of particular interest to me are the sometimes long panning shots and sometimes still shots that appear as jump-cuts of the multistoreyed apartment blocks. The shots serve no narrative function, neither are they point-of-view shots. Often they create a deliberate spatial disorientation. The view of the building will be limited to the rows of blank uniform windows that seem to have no beginning or end as the contours of the building; its top and bottom are excluded from the frame (see fig. 2). This imagery has a long cultural and cinematic history. The massive blocks of apartment highrises are called in Russian novostroiki [new construction sites], residential neighbourhoods or Soviet suburbs, removed from the city centre both in prestige of living arrangements and in terms of accessibility to work and leisure. These suburbs are most typically associated with the stagnation era of the 1970s-1980s and the upward mobility of the Soviet middle class that starts as early as the late 1950s, manifested most aptly in the acquisition of a separate apartment for an individual family (as opposed to communal living). Apartments and the family members sharing them, exchanging them through divorces and marriages, the notorious Soviet lack of space and resulting multi-generational conflict, became one of the cultural tropes of late Soviet culture amply explored in literature and film. ${ }^{3}$ Built virtually in every Soviet city, the novostroiki are cookiecutter neighbourhoods with identical prefab architecture and structure. An average block includes a grocery store, a school, a day care, an inner yard with a playground, etc. As such, novostroiki represent both the bourgeois conformity of a more consumer-oriented lifestyle and oppressive Soviet uniformity. 
In Soviet filmmaking the novostroiki were immortalized in the cult melodrama or dramedy Irony of Fate [Ironiia sud'by] by Eldar Riazanov, from 1979, tellingly made for Soviet television for New Year's eve celebrations - a film that the residents of the Soviet suburbs might enjoy as they celebrate in their own apartments watching their own TVs. In that popular film, the unfortunate sameness of the Soviet housing projects leads to a case of mistaken identity (of the city) and an unexpected romance. The film gently pokes fun at the unpretentious consumerism of the Soviet citizens who not only live in identical apartments but have identical furniture and dishware. The film also makes an oblique point about the graver consequences of totalizing uniformity that starts with the house appliances and ends with street views and brainwashed minds. Dead Daughters is far removed both from the Soviet context of the 1979 Irony of Fate and its melodrama genre. It nonetheless employs the same cultural trope, drawing attention to the uninspiring novostroiki facades in almost identical shots (most likely a conscious quote) and implying the similar critique of conformity, uniformity and anonymity. Only this time around these images of bourgeois conformism and comfort are packaged in the context of both the horror genre and contemporary Russian middle-class lifestyle.

The ubiquitous novostroiki are only a part of the film's obsession with the cookie-cutter living spaces: we meet all the friends in the apartment, one of the friends sells an apartment with a murderous history, another barricades himself in his apartment, the "final girl" faces the ghosts in her dark and barren apartment that looks a lot like a theatre stage by the time of the final showdown. The interchangeability of public and private spaces, in which neither is safe from the ghosts, hints at the merging of public and private in the culture of the Soviet Union and a certain transparency that is a necessary consequence of uniformity. The 1979 Irony of Fate highlights the complexity, opaqueness and diversity of human interaction as a counterpoint to the imposing conditions of uniformity and social conformity, creating a nuanced vision of society and human relations. The conclusions we can draw from Dead Daughters, however, are far more straightforward: the new "bourgeoisie" of Russia is as conformist as the Soviet middle class and its constricted housing bliss. The supernatural intervention is sort of a divine punishment for the banal and self-satisfied lives of the protagonists. While it is easy to see how the conclusions the film draws might be interpreted as an oversimplification, what interests $m e$ is the choice of metaphors and connections that the film makes.

The film suggests that both the old comforts of the Soviet stagnation era of the 1970s and the new comforts of the 2000s, the Putin era, share a continuity of values and risks. The values are the stability and abundance of consumer culture of prosperity, something that is experienced almost exclusively by 
the post-Soviet generation portrayed in the film. The risks express the hidden potential of that stability to be fake, its other side being totalitarian oppression. Today's consumerist lifestyle has a calm surface that could dangerously erupt into the accidental chain of lifeshattering events, or into a horror story. Space becomes a link that makes this connection specifically to a Russian viewer. By interspersing the shots of novostroiki without apparent relation to the narrative or consistent visual style, the film creates a metaphor that aims at both historical continuity and authentic "local" validation of the horror film. At the same time the novostroiki sequences feel disjointed and removed from the story. The film's desire to create a product allied philosophically and aesthetically with the tradition of art cinema manifests itself mostly via hand-held camera work, a cliche of the art house style. The film's disjointed storytelling, often aided by the out-of-place images of novostroiki, diminishes its genre potential, making Dead Daughters an ambivalent film that in Russia never quite reached the critical acclaim of the art house or the mainstream popularity of genre cinema. ${ }^{4}$ This ambivalence is significant as it showcases the film's search for the cinematic solution that would produce "Russian horror," in which both the authentic Russian component and the generic horror component appeal equally to the audience. In search of this elusive combination the film revisits history, re-imagines public and private spaces and aligns itself with both a familiar and much-venerated tradition of art cinema (represented by Andrei Tarkovsky, Sergo Paradzhanov or Aleksandr Sokurov) and the foreign tradition of horror genre.

The film Trackman does not have similar art cinema ambitions. Trackman was financed by Fox Searchlight and is more of a standard slasher horror film with very little to distinguish it from any other example of the genre done in the past few years in North America (the recent remakes of Friday the Thirteenth, Last House on the Left or I Spit on Your Grave are good examples of this streamlined and very formulaic slasher horror). Trackman has fast-paced editing, a haunting soundtrack and excellent visuals - the film uses various colour schemes that make the Moscow underground assume an entire palette rather than being simply dark. The film takes no risks and is squarely within genre conventions with a predictable storyline and reasonably sympathetic young protagonists. Where the films gets interesting is its use of space as the main attraction and the force behind narrative development. Shot in the vast Moscow metro system, the film takes advantage of its labyrinth-like spatial dimensions and its cultural clout. The Moscow metro has a long-standing reputation as the prize achievement of the Soviets in the Stalinist era, a symbol of technology, progress and power of the new Soviet state. The metro's lavish unique interiors make it a prized tourist attraction to this day. At the same time, the metro and its extensive network of tunnels is a space of thriving urban legends, stories of secret government 
passages, nuclear war shelters and buried treasures. A case in point is a subculture of "diggers," (diggery in Russian) who engage in a kind of extreme sport exploring Moscow's underground tunnels, often in search of WWII artefacts and other secrets.

Trackman exploits this space, already rife with myths, by ensuring that a masked mutant monster lurks deep underground. The spaces in the film reinforce this impression by contrasting the initial robbery scene, filmed in a light, modern building made of glass, with the majority of the film shot in the actual underground, with a lack of light and subdued colours. The underground is presented not only as an unknown territory, where one might find unnamed dangers, but also as a space that combines the natural and cultural markers of an abandoned civilization (see fig. 3). Thus, the tunnels that the characters perpetually wander have both prominent signs of decay and of nature, which has overtaken the civilized space. The underground is filled with abandoned carts and tools, hanging wires, barely functioning or broken lamps. At the same time fog, dripping water, and rat infestations come in at crucial moments to create suspense around the appearance of the monster-Trackman and disorient the characters. Similarly, Trackman himself becomes the manifestation of this abandoned civilization par excellence. When we encounter him in his lair, it is filled with random technology, wires, tools and remnants of machinery. It looks like a laboratory, especially when we witness Trackman methodically dealing with the eyes he gouged out. However, all this technology is tangled up in a meaningless way that creates an impression of the lair of the beast, a cave lined with signs of the bygone civilization, whose meaning has been lost (see fig. 4).

What piqued my interest in Trackman was its promotion slogan "old nightmares get new face." The "oldness" of the Trackman narrative goes back to an alleged urban legend that describes Trackman as a Chernobyl rescue worker who has gone mad after being poisoned by radiation and was held prisoner underground by the government until he escaped (or, rather, the government, that of the Soviet Union, ceased to exist and left him to his own devices). The old nightmare of Chernobyl, in other words, comes back to haunt contemporary Russia, a careless prosperous civilization of sleek bank interiors, middle class professionals and chivalric robbers, all of which has forgotten what it is literally built on top of. Trackman, the monster, represents the rupture between the past and the present, the abandoned and forsaken legacy that is uncomfortable and dangerous. The space of the Soviet metro is particularly suitable for the confrontation with the forsaken past. In his analysis of the metro as the prized object of Stalinist civilization, Boris Groys (2003) writes:

If classical utopianism, including avant-garde utopianism, wanted to construct a heaven on earth, then Stalinist culture constructed heaven 
underground, that is, in mythological terms, in hell... The conquering of hell simultaneously implies the conquering of the past. Not only the living, but also the dead - who were banished beneath the earth by the logic of historical life - were to be admitted to the totality of Stalinist culture... Thus the Moscow metro stations affirm the image of a never-existent, utopian, transformed, and saved past (117-118).

The initial vision of the Moscow metro makes it the place of the Soviet utopian realization of the predictability of history, its incontrovertible march towards triumph of communism. The contemporary gaze of the horror film literally transforms the utopian teleology into a dystopian rupture. The unaware characters descend into the circles of a real hell, not the tamed hell of the Soviet utopian metro project. It is also significant that Trackman extracts eyes from his victims, as the ability to see, or to witness history has been taken away from him and from the people who live on top of the forsaken civilization. While being a visually sleek and narratively conventional horror film, Trackman channels ambivalence about the Soviet past and the interpretation of Russian history. While it is well documented by scholars (see Lipovetsky or Larson for examples) that Putin's "velvet restoration" taps into the Soviet nostalgia, films like Trackman, being unpretentious cultural productions, alert us to collective anxieties associated with a nostalgic vision of history. The Moscow metro, a pinnacle of cultural conquest of nature and subjugation of historical chaos into teleological order, designed as the symbol of the utopian golden era, in Trackman becomes a space built on blood and rife with peril. It forewarns about wilful blindness and the uneasy connection, contrary to what nostalgia have us believe, between the past and the present.

An even more articulate problematization of the Soviet past and the role of nostalgia is evident in Night and Day Watch duology. Mikhail Ryklin (2006) asserts in the collection Watch as a Symptom that the good and bad "others" are divided in the film by political markers. The "night watch" good guys are marked as Soviet: they drive an old car with a Soviet logo; their organization is disguised as a government agency with a typical Soviet abbreviation. The bad vampires are marked as "new Russians" - the generation of Russian nouveau-riches that prospered in the late 1990s. The "day watch" others lead a decadent luxurious lifestyle, and indulge in the latest gadgets and video games, unlike the modest "night watch" folk, whose equipment (magical and otherwise) looks like it was designed in the 1970s. The incorporation of Soviet nostalgia into the films became the ground for Russian critics like Ryklin to link the Watches specifically to Vladimir Putin's presidency and its pandering to Soviet nostalgia for political gain. Mikhail Ryklin also comes to the interesting conclusion that the "others," Soviet or nouveau-riches, are distanced from regular humans, who become essentially 
"food" for superior beings of all moral orientations, who are preoccupied mostly with maintaining the balance of power between themselves. This is evident when one looks at the space in the films - the Watch films' world is not air-tight or separated from the real world, as could be the case in a more conventional fantasy. Instead, it is deliberately set in contemporary Moscow, in which ordinary people appear only as pawns in the games of superior creatures. Ryklin sees it as a metaphor of the grim political situation in contemporary Russia, in which, he asserts, moral judgement has become relativized.

I agree with Ryklin that the Watch films exemplify the balancing act between Hollywood thrill ride, nostalgic reference, and moral ambivalence. The films not only mark characters and situation as Soviet and post-Soviet, the distinctions between Soviet and new Russian are obviously there, but they are part of a larger narrative that the films construct. The two films are a continuous narrative, in which a "night watch" member Anton Gorodetsky, the "Russian Neo," (played by Konstantin Khabensky) makes a mistake back in the early 1990s that comes back to haunt him a decade later. By fixing that mistake, he turns the narrative around, going back in time and saving the world. He is shown returning to the brightly lit, spring-like 1990s, while he happily strolls down a boulevard and meets his romantic interest, long before they become aware of their dormant superpowers and the burdens that they will bring. It is truly a return to a state of innocence. Notably, the two rival leaders of the "day" and "night" watch sit right there playing chess, benevolently looking at the hero and his reversal of fortune. It is also important to note that the hero has reverted to his human state by amending the mistake, making the struggle between the goodSoviet watch and the bad-new-Russian watch irrelevant. In other words, I argue that the Watch films promote continuity and coherency of the historic narrative, reconciling the innocent nostalgic past with what is perceived as the decadent and westernized culture of today's Russia. The naive gesture of turning back time and fixing everything retroactively is, in a sense, a longing for closure. It provides the magic solution that closes the breach in historic contingency. The Watches do not only appropriate Soviet nostalgia, making sense of history, but also contain the times of crisis and transition, known in Russia as the "wild 1990s," in a safe retroactive package. The time of confusion acquires a linear timeline, its difficulties explained, despite being a period rife with economic struggles and crisis of identity. Even if such appropriation creates a fairy-tale vision, the important part is that these films provide us with a vision of history, and this narrative of history (unlike, perhaps, real history) makes sense.

Preoccupations with history, along with the desire to conform to the aesthetics of Hollywood genres, inform recent Russian horror films. While horror still holds only a marginal place in 
Russian mainstream culture, I believe it explores and exemplifies the tensions that characterize contemporary popular filmmaking in Russia - the need to be authentic and the need to compete with Hollywood on its own turf, to create popular filmmaking that is accessible to today's audience. Considerations of time and space in the films play an important role in establishing horror's balancing act between national sensibility and generic plausibility.

\section{Works Cited}

Beumers, Birgit. A History of Russian Cinema. Oxford: Berg Publishers, 2009. Print.

Bhabha, Homi. "Of Mimicry and Man: the Ambivalence of Colonial Discourse." The Location of Culture. London: Routledge, 1994. 85-92. Print.

Bordwell, David. The Way Hollywood Tells It. Los Angeles: University of California Press, 2006. Print

Carol J. Clover. Men, Women, and Chain Saws: Gender in Modern Horror Film. Princeton, NJ: Princeton UP, 1993. Print.

Condee, Nancy. The Imperial Trace. Oxford: Oxford UP, 2009. Print.

Groys, Boris. "The Art of Totality.” Landscape of Stalinism: The Art and Ideology of Soviet

Space, ed. by Evgeny Dobrenko and Eric Neiman. University of Washington Press, 2003. 96-122. Print.

Larsen, Susan.”National Identity, Cultural Authority, and the Post-Soviet Blockbuster: NikitaMikhalkov and Aleksei Balabanov." Slavic Review 62.3 (2003): 493-511. Print.

Lipovetsky,Mark. "Post-Sots:Transformations of Socialist Realism in the Popular Culture of the Recent Period." The Slavic and East European Journal 48.3 (2004): 356-377. Print.
Lowenstein, Adam. Shocking Representation: Historical Trauma, National Cinema, and the Modern Horror Film. New York: Columbia University Press, 2005. Print.

Ricouer, Paul. Time and Narrative. Volume 1. Chicago: Chicago UP, 1990. Print.

Ryklin, Mikhail. "Hollywood Inside Out. Interview with Anna Al'chik" [Gollivud naiznanku. Interv'iu s Annoi Al'chik]. Watch as a Symptom [Dozor kak simptom]. Saint Petersburg: Seans, 2006. 36-49. Print.

Shohat, Ella and Stam, Robert. Unthinking Eurocentrism: Multiculturalism and the Media. New York: Routledge, 1994. Print.

Woll, Josephine. "Exorcising the Devil: Russian Cinema and Horror." Horror International, eds. Steven Jay Schneider and Tony Williams. Detroit: Wayne State UP, 2005, 336-358. Print.

Wood, Robin. "The American Nightmare: Horror in the 70s." Hollywood from Vietnam to Reagan. New York: Columbia UP, 1986. 70-94. Print.

\section{Filmography}

Blair Witch Project. Dir. Myrick \& Sanchez. Haxan Films, 1999.

Day Watch [Dnevnoi dozor]. Dir. Timur Bekmambetov. Bazelevs Productions, 2006.

Dead Daughters [Mertvye docheri]. Dir. Pavel Ruminov. Praktika Pictures, 2007.

Friday the 13th. Dir. Sean Cunningham. Paramount Pictures, 1980.

Halloween. Dir. John Carpenter. Compass International Pictures, 1978.

Irony of Fate or Enjoy Your Steam-Bath [Ironiia sud'by ili s legkim parom]. Dir. El'dar Riazanov. Moscow Film Studio, 1979.

My Bloody Valentine. Dir. George Mihalka. Canadian Film Development Corporation, 1981.

Nightmare on Elm Street. Dir. Wes Craven. New Line Cinema, 1984. 
Night Watch [Nochnoi dozor]. Dir. Timur Bekmambetov. Bazelevs Productions, 2004. Psycho. Dir. Alfred Hitchcock. Shamley Productions, 1960.

Ringu. Dir. Hideo Nakata. Omega Projects, 1998.

Texas Chainsaw Massacre. Dir. Tobe Hooper. Vortex, 1974.

The Matrix. Dir. Wachowsky Brothers. Warner Bros. Pictures, 1999.

The Ring. Dir. Gore Verbinsky. Dreamworks SKG, 2002.

The Snake Well [Zmeinyi istochnik]. Dir. Nikolai Lebedev. Gorky Studio, 1997.

The Touch [Prikosnovenie]. Dir. Albert Mkrtchan. Studio Trans-F, 1992.

The Vampire [Upyr']. Dir. Sergei Vinokurov. Gorky Studio, 1997.

Trackman [Putevoi obkhodchik]. Dir. Igor Shavlak. Importfilm, 2007.

Viy. Dir. Konstantin Ershov \& Georgy Kropachev. Moscow Film Studio, 1967.

\section{(Endnotes)}

1 Susan Larsen (2003) mentions that “...in the first post-Soviet decade, Russian filmmakers have watched their domestic audience, their international renown, and their cultural authority shrink and all but disappear, as the annual production of feature films sank from an all-time high of 300 films in 1990 to a near all-time low of 28 in 1996, then rose again to hover between 30 and 50 per year between 1997 and 2000" (491).

2 The "final girl" is a term coined by Carol Clover (1993) in reference to the slasher horror trope of a last-standing female survivor.

3 Housing provided a rich ground for exploration in both censored Soviet literature such as Our Circle [Svoi krug](1979) by Liudmila Petrushevskaia and published works, such as Yuri Trifonov's Exchange [Obmen] (1969). The thorny issue of housing is also subject in many films of the Soviet and early post-Soviet era, ranging from innocuous melodramas like Singles Are Granted a Dormitory Room [Odinokim predostavliaetsa obshchezhitie] (Samsonov1983) to the satirical The Fountain [Fontan] (Yuri Mamin 1989).

4 See Russian reviews of the film that stress (and often object to) the combination of art cinema and mainstream conventions in the film. As in this review by Roman Kulanin for online journal KinoKard (February 4, 2007): http://www.kinokadr.ru/articles/2007/02/04/ deaddaughters.shtml

Volha Isakava is a Replacement Assistant Professor of Russian at the University of Ottawa, Canada. Her research interests include contemporary Russian and post-Soviet cinema and culture, transnational cinema and the critical junction of cinema and history. She recently graduated from the University of Alberta where she wrote her doctoral thesis about the cinema of perestroika and how its historic transition has been reflected in Russia's arguably bleakest cinematic trend "black films" or chernukha.

Volha Isakava enseigne à l'Université d'Ottawa comme professeure adjointe. Ses recherches portent sur la culture et le cinéma post-soviétique, sur la contemporanéité russe, sur le cinéma transnational, et sur la coalition critique entre le cinéma et l'histoire. Elle a obtenu son doctorat de l'Université de L'Alberta avec une thèse sur le cinéma de la perestroïka, qui se concentre sur la réverbération de cette transition historique dans les " chernukha ", parfois considérés comme les plus sombres films de la Russie.

Copyright Volha Isakava. This article is licensed under a Creative Commons 3.0 License although certain works referenced herein may be separately licensed, or the author has exercised their right to fair dealing under the Canadian Copyright Act. 


\section{"We are Resilient by Force, not by Choice" TERRIFYING BOMBAY IN NEW BOLLYWOOD CINEMA}

\section{MEHELI SEN}

As the home of the Hindi film industry, Bombay has occupied center stage in Bollywood's imaginary of the modern metropolis. Over the last decade, however, cinematic representations of Bombay have undergone drastic transformations: from being the terrain of gang warfare in the $80 \mathrm{~s}$ and $90 \mathrm{~s}$, the cinematic city has become the primary target and habitat of global terrorism. Bollywood's rendition of a city perpetually under siege resonates with the series of attacks that have plagued the hapless metropolis since 1993. I interrogate Bollywood's shifting relationship with its hometown and its audiences via two landmark films-A Wednesday and Aamir (2008). I am especially interested in the dialectics of ordinariness and extraordinariness that inflect articulations of the city and its citizenry. In both films a 'common' individual is called upon to perform uncommon tasks in order to negotiate the space of potential devastation that is now Bombay. Spectacular performances of technologies and stylistic devices generate the cinematic city as an affective locus of dread. I pay special attention to cinematography and editing, which enable the filmic figuration of the city in these recent films.
Bombay, le centre du cinéma Hindi, a toujours servi d'image de la métropole moderne dans l'imaginaire de Bollywood. Néanmoins, au cours de la dernière décennie, la représentation cinématographique de Bombay a subi des transformations drastiques : la ville antérieurement connue pour ses guerres entre bandes dans les années 80 et 90 est maintenant un lieu et une cible important du terrorisme global. Le portrait d'une ville assiégée correspond à une série d'attaques qui ont hanté la métropole malchanceuse depuis 1993. Cet article propose d'analyser le rapport fluctuant entre Bollywood et sa ville originelle à travers deux films marquants "A Wednesday » et "Amir » (2008). L'accent est mis sur la dialectique ente l'ordinaire et l'extraordinaire qui module les articulations de la ville et des citoyens. Dans les deux films un homme ordinaire est convoqué à exécuter des taches hors du commun afin de négocier sa position dans l'espace de dévastation potentielle qu'est désormais Bombay. Les performances spectaculaires de la technologie et des appareils stylistiques font de cette ville cinématographique un lieu affectif de la peur. L'article se concentre sur les stratégies cinématographiques et de montage qui dominent la mise en scène de la ville dans ces films. 
The Battle of Bombay is the battle of the self against the crowd. In a city of 14 million people, how much value is associated with the number one? The battle is Man against the Metropolis, which is only the infinite extension of Man and the demon against which he must constantly strive to establish himself or be annibilated. A city is an agglomeration of individual dreams, a mass dream of the crowd. In order for the dream life of a city to stay vital, each individual dream has to stay vital. (Mehta 539)

The sense of a city experiencing disorder and crisis dominates narratives of contemporary Bombay in both journalistic discourse and popular perceptions of the city... Crisis is... both an intense experience as well as a metaphor for the contemporary cityscape. For the film industry the experience of crisis can only be rendered to their audiences through narratives of despair. (Mazumdar 421; emphasis in the original)

For decades, before becoming the cinematic city of death and devastation, Bombay has harnessed myriad fantasies for popular cinema in India. As the commercial capital of India-once as the most important manufacturing hub and lately as a crucial node in the travels of global capital-as well as the home of the film industry, the city has occupied center stage in cinema's imaginary of the modern metropolis. In fact, Bombay's iconic figuration in Hindi film can hardly be overstated. However, the cinematic city has undergone crucial transformations over the years: in the 50s when the postcolonial national imaginary was animated by aspirations of development and modernity, Bombay became the site for the cinematic elaboration of these dreams; representations of bustling urban spaces belonged to the same iconic register of Nehruvian development, as did bridges, dams and factories. In the 70s, as India entered into a phase of profound political disquiet, the cinematic Bombay morphed into a gangland where smugglers, crime bosses, molls, and the morally ambiguous hero came to be its foremost denizens. In the last two decades following the advent of economic liberalization, Bombay has transformed once again: for Hindi cinema, it has become either a glitzy playground for the super wealthy, or, an impenetrable and terrifying refuge for underworld criminality or global terrorism. Madhava Prasad has argued for the metaphorical nature of Bombay as popular cinema's ur city:

For popular Hindi cinema the metropolis of choice has always been Bombay. From Miss Frontier Mail (dir. Homi Wadia, 1936) to Satya (dir. Ram Gopal Varma, 1998), Hindi cinema's narrative geography, which is otherwise extremely unspecific, incorporates as a significant turn in the plot, the event of 'going to Bombay.' The city itself figures with varying degrees of specificity, a variance that can be explained in terms of both technological developments making possible a greater investment in realism, as well as the particular genre of film that is in question (86)

The question of realism is a crucial one for my discussion here, because the films in question not only render the city tangible as an affective terrain of fear, via a careful deployment of cinematic technologies, but also because they 
resonate with real-life terror attacks that the metropolis has suffered repeatedly in recent decades.

The recent cycle of terror attacks on the city began in 1993; following the demolition of the Babri Mosque in Ayodhya by a mob amassed by the Hindu Right, the Muslim underworld responded by executing a series of carefully coordinated bomb blasts in the city. 250 civilians were killed and hundreds injured in this first bout of violence that profoundly damaged Bombay's image as India's cosmopolitan capital. Unfortunately, the attacks set a dangerous precedent; since then, cycles of terror attacks have become horrifyingly quotidian in the city: on December 6, 2002, on the $10^{\text {th }}$ anniversary of the Babri Mosque incident, a blast on a bus killed two people and injured many others. In March 2003, a bomb exploded in a train compartment killing 10 people; later that year, two bombs exploded in South Bombay, one near the Gateway of India monument and another at Zaveri Bazar. According to published reports, at least 44 people were killed and over a hundred injured in this attack. In 2006, a series of seven bomb blasts killed hundreds of commuters on suburban trains, over a span of just eleven minutes; the reported casualties were over 200. In 2008, yet another series of attacks were carried out in different tourist and commercial locations in the city, this time killing over 150 people, including some international tourists, several attackers and security personnel. For the purposes of my argument, it is crucial to note the multi-pronged nature of these onslaughts: the terroristsallegedly belonging to several militant Islamic organizations from India and Pakistan, notably Lashkar-e-Toiba and SIMI-simultaneously carried out operations in several far flung regions of the city. A degree of communicational sophistication and intricate planning attended to the execution of this violence.

It is therefore no accident that the cinematic Bombay is now an emblematic habitat of global terrorism. Several recent films, notably Black Friday (dir. Anurag Kashyap, 2004), Aamir (dir. Raj Kumar Gupta, 2008), A Wednesday (dir. Neeraj Pandey, 2008), Delhi 6 (dir. Rakeysh Omprakash Mehra, 2009), and others envisage the city as a dreadful site of potential carnage where terror networks remain robustundetected, unchecked and pervading everyday lives and spaces. These films, mostly thrillers, also underscore the competence-both organizational and informatic-that the attackers have demonstrated in recent years. Needless to say, the fear of technological and organizational sophistication harnessed by alleged terrorists has reached new levels after 9/11.

The twin vectors of space (Bombay city) and time (following the bomb-blasts in 1993) are important for my analysis here, because the filmic city emerges within a special kind of space-time interface. Throughout the rest of this analysis, I hope to demonstrate precisely the manner in which "Bombay" comes 
to be figurable, by moving between the spatial and temporal axes of the films in question. The question of realism is especially pertinent to this analysis, because the films I analyze here have been lauded for their "realistic" portrayal of the city and its everyday rhythms. As Moinak Biswas has argued, the city of Hindi cinema has acquired a certain naturalism and density in recent years, especially in the gangster genre, which shares certain key attributes with the films I discuss here: "We are trapped inside the city; the extended initiation in violence makes the character an expert user of the city, whose slums and lanes are choreographed into a performance of shock and survival. What does this mean in terms of film language? Primarily, there is a technical mobilization that seeks to create a rapport between the urban sensorium and the perceptual regime of the film. (In the process, technology itself often rises to the surface as performance)." (online) This, then, is a special kind of realism. ${ }^{1}$ Paying particular attention to this "performative" aspect of cinematic technology, in what follows I will investigate exactly what kind of "urban sensorium" is generated in this newer iteration of the thriller-the terrorism film.

\section{Ordinary Citizens, Extraordinary City}

I will discuss two recent and much discussed films from 2008: Aamir and A Wednesday. Both texts bristle with the dread of attacks on the hapless metropolis, but in markedly different ways: while the eponymous protagonist of Aamir (Rajeev Khandelwal) steps into the fearful city as an unwitting and somewhat naïve outsider, the unnamed hero of $A$ Wednesday (Naseeruddin Shah) eloquently invokes the gruesome attacks that have devastated the city in his final, climactic soliloquy to the commissioner of police. Both films bear the dreadful memory of death and destruction at their affective cores; these are, emphatically, trauma texts, which return repeatedly to $\mathrm{t}^{2}$ he moments of violence. What makes these texts especially interesting for the present inquiry is that they exist in a time warp: while neither film's diegesis takes place at the moment of the blasts, ${ }^{3}$ both imagine the metropolis as a space of potential devastation. The bomb blasts figure in these narratives not simply as the past of the city, but as an always already accessible mode of recall and anticipation-a past that is always present, and a present that moves inexorably towards an inevitable future-another attack. What we have here is a traumatic temporality that has lost all logic of linearity; the city of Bombay exists in the films caught in a dreadful cycle of event, delay and repetition. ${ }^{4}$

Brian Massumi's recent work on "the ontology of the threat" offers a fecund point of entry into the temporal dispensation harnessed by these films:

"Threat is from the future. It is what might come next. Its eventual location and ultimate extent are undefined. Its nature is open-ended. It is not just what it is not: it is not in a way that 
is never over. We can never be done with it. Even if a clear and present danger materializes in the present, it is still not over. There is always the nagging potential of the next after being even worse, and of a still worse next again after that. The uncertainty of the potential next is never consumed in any given event. There is always a remainder of uncertainty, an unconsummated surplus of danger." (53)

What Massumi alerts us to is the threat's constant deferral-even as an event occurs-as well as its limitless potentiality in the future. It is precisely these characteristics of the threat that enables the protagonist in A Wednesday to easily paralyze the law enforcement system of the city, because as the chief minister of the state succinctly states, "there must be no blasts in Bombay today." The city is a perpetual hostage to threat. The metanarrative of past/ future violence enables the cinematic figuration of Bombay as a city under siege- - city that can only be conceived as imperiled. The suspension of linear time endows the cinematic city with a terrifying extraordinariness: Bombay is special because at any moment it may cease to exist altogether. The films situate themselves in a moment of dreadful apprehension until the next attack. Massumi also points out that the existence of a "real" threat is immaterial in this context because, "threat is not real in spite of its nonexistence. It is superlatively real, because of it." (53) In both films under discussion here, the threat is "real" insofar as actors and potential actions are concerned; however, what the films more profoundly invoke is the idea that in contemporary Bombay, the threat cannot be anything but real. The cinematic city emerges through a particular kind of organization of visual material that privileges fear and dread above all other affective registers-fear is what conjures up the city, brings it into being, as it were: "fear is the affective fact of the matter." (Massumi 54 ; emphasis in original)

While the metropolis is rendered extraordinary through the logic of temporal re-organization, its citizens remain defiantly ordinary. In fact, both Aamir and A Wednesday expend significant narrative energy in buttressing the unremarkable lives of its main protagonists. A bewildered Aamir keeps reiterating his status as an ordinary citizen to the disembodied voice on the phone, to no avail. In some ways, however, he is specialand a rare character for Bollywood's representational matrix-a modern, secular, educated, progressive Muslim. The film chronicles a harrowing day in his life, as the spectral voice on a mobile phone irrevocably changes Aamir's destiny.

Predictably, the voice belongs to the fanatical leader of a terrorist outfit who deploys the hapless hero to plant a bomb in a crowded residential area in the city. Aamir sheds the ordinariness he has desperately clung to at the very end, when, in an uncharacteristic gesture of defiance, he commits suicide 
to save numerous citizens of Bombay. $\mathrm{He}$ becomes at this instance the very opposite of a suicide bomber-the destruction of his body remains singular, isolated and in the terrorist's scheme of things, completely meaningless. It is this final gesture of courageous selfdestruction that bestows on him the mantle of heroism, one he has frantically tried to avoid for the bulk of the film. The voice on the phone (the terrorist mastermind remains nameless and largely faceless) coerces, cajoles and, of course, threatens, just so Aamir would understand the profound significance of his name-the word 'Aamir' refers to 'leader' in Arabic. Ironically, it is by rejecting the mantle of leadership of the Islamic brotherhood that Aamir becomes a hero in death.

The protagonist of A Wednesdaynameless, because names carry the marker of religion in South Asiastraddles the ordinary-extraordinary dialectic in a different manner. The post-prologue sequence offers a typical montage of the cityscape: bustling shots of the metropolis, gargantuan traffic jams, hurrying crowds, train stations and trains crammed full of people, citizens scurrying to reach workplaces on time. Amidst this city in motion, we see our protagonist apparently hurrying in tandem. However, the film denotes his extraordinariness by isolating him in vibrant color, while the rest of the city is bleached out, seemingly drained of all hues. Bombay appears largely gray and shrouded in smog in A Wednesday, a city that conceals and harbors unseen threats at every moment.
While singled out for our attention, he remains emphatically ordinary in other ways-clearly middle class with no specific facial or bodily characteristic, he easily blends in as one in a crowd of millions. (see fig. 1) His ordinariness, for example, is also signposted through a phone conversation in which his wife reminds him to pick up groceries on his way home; this scene remains a surplus within the film's stringent narrative economy, but functions as a scaffold to the protagonist's married, bourgeois and conventional profile. The extraordinary strength and willpower of this man becomes clear only a few minutes later when he brings the entire law and order machinery of the city to a shuddering halt.

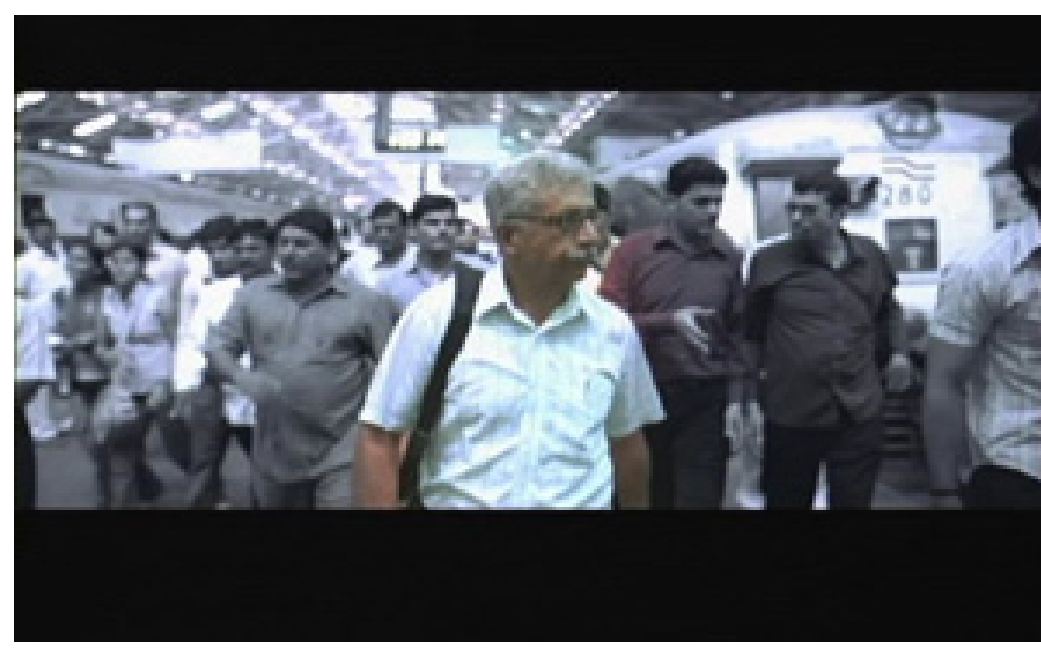

Fig. 1

This protagonist-older, unarmed, middle-class and clearly educatedforces the police commissioner as well as the administrative officials of the state to deliver four very specific terroristsinvolved in the attacks on the city in 1992-93, 2006, etc.-to a deserted aviation base, and then assassinate 
them en masse. His bargaining chip is his assertion of having planted five bombs in five different city locations; he simply threatens to detonate these if the state refuses to accede to his demands. The narrative is, thus, a monumental confrontation between the staterepresented here by the beleaguered law enforcement machinery-and the citizen, now in the garb of a vigilante seeker of justice. Initially thought to be the leader of a sophisticated terror network-Al Qaeda is mentioned several times-he turns out to be an ordinary citizen of Bombay, but one bent on meting a particular kind of justice on the criminals in question. In accomplishing this astonishing task, he deploys the popular news media as well as an extraordinary range of electronic gadgets that he has amassed on the rooftop of a deserted, halffinished skyscraper, one among many available in the building boom of the city's suburbs. In his final telephone call to the commissioner of police, Rathod (Anupam Kher), he invokes this ordinary-extraordinary dialectic himself: he states that he is a "stupid common man," the kind who is routinely killed in the terrorist attacks on the city and justice is either delayed or simply not forthcoming. Voicing the collective frustration of millions of citizens of Bombay, he declares, "people are angry, don't try us. We are resilient by force, not choice." In explaining his actions of the day, he says he is merely "cleaning house" of the pests that infest it-the metaphor of home and pestilence remain compelling indictments of the administration's apparent inability to either stop the successive waves of attacks on Bombay or to bring the criminals to justice in a timely fashion. At Rathod's persistent questioning, he also reveals that it is ridiculously easy to both gather the raw materials and to make bombs-instructions are easily available on the internet-once again buttressing the failure of the law and order apparatus to eradicate the threat of terror attacks in any meaningful way. The central tool of narrative progression in A Wednesday is conversation-a series of them between Rathod and our unnamed protagonist. In the final climactic chat, he informs the astounded commissioner that he interprets the series of terrorist attacks on Bombay as questions, mocking gauntlets that the terrorists have thrown down against the hapless citizenry. These were posed on Tuesday, and he is simply responding to them on a Wednesday.

\section{Cityscape of Dread as Spectacle}

In her essay titled "Spectacle and Death in Bombay Cinema", Ranjani Mazumdar makes a crucial distinction between two different representational modalities via which the city of Bombay has come to be figurable in recent Hindi cinema: as either spectacular interiors in family films or as dystopic, derelict outdoors in the gritty, realistic gangster genre:

The panoramic interiors of the family films combine design techniques with architectural space to create a "virtual city" where the "global" family can reinvent "Indianness" and modernity. 
In this scenario, the space of the Bombay street, the chawl, the train, and the crowds, which were always central to the narratives of popular cinema, are consistently marginalized. In contrast, the films of the new gangster genre conduct an elaborate exploration of urban space. The dark alleys, crowded streets, the slums, the peeling walls, and the claustrophobic chawls are all on display. Unlike the family films, where public city space is erased, the underworld films negotiate the city through a hyper-real mode that relies on a combination of violence, technology, masculinity, and urban space (402).

Mazumdar, thus, situates Bollywood's "spectacular global city" in opposition to what she calls the city of "spatial disenchantment" (426), as navigated by the urban gangster genre. Pushing her argument further, I would like to ask, what happens when the dark, sinister, dystopic city is simultaneously rendered spectacular through film style? Both Aamir and A Wednesday conjure up the city of Bombay as a terrain of danger, dread and potential destruction. This affective, hyper-metropolis comes to be figurable through the extensive use of cinematic technologies and stylistic tools, particularly via a careful orchestration of mise-en-scene, cinematography and editing.

In $A$ Wednesday, we are shown three separate, discrete loci of action-the protagonist's perch on the rooftop, the central 'war room' of the police high commission and the disparate spaces

IMAGINATIONS・ISSUE 4 - 1, 2013•58 of the city that the policemen traverse in their hunt for the nameless/faceless caller. The three locational clusters do not overlap but are constantly brought together through the logic of temporal simultaneity; the cinematography and editing styles of the film insistently juxtapose these spaces in order to amplify the mounting sense of urgency experienced by the law enforcement authorities. The primary stylistic techniques deployed here are crosscutting and the use of split screen imagery, both of which enable the spaces to be tied together in an inexorable feedback loop: what happens on the rooftop affects the war room, which affects the battery of policemen combing the city, which is then relayed to the protagonist on the rooftop. Telephone conversations between Rathod and the protagonist are often presented via the split screen-a device that enables us to observe the expressions and reactions of both men simultaneously, and to read the film as a contest of wills between opponents who are equally matched. (see fig. 2). The split screen also generates a hyper-location of the spectator: a terrain of visibility made possible only through the virtuoso use of technology-both cinematic and communicational. As Ravi Vasudevan has suggested, "such a hyper-location, braiding the spectators into spaces that are differentiated, draws upon the omniscient conventions of classical narration. Separated spaces can be figured as adjacent, as collapsing into each other, and as rapidly negotiable, via that key apparatus of contemporary communication, the mobile phone" (66). 


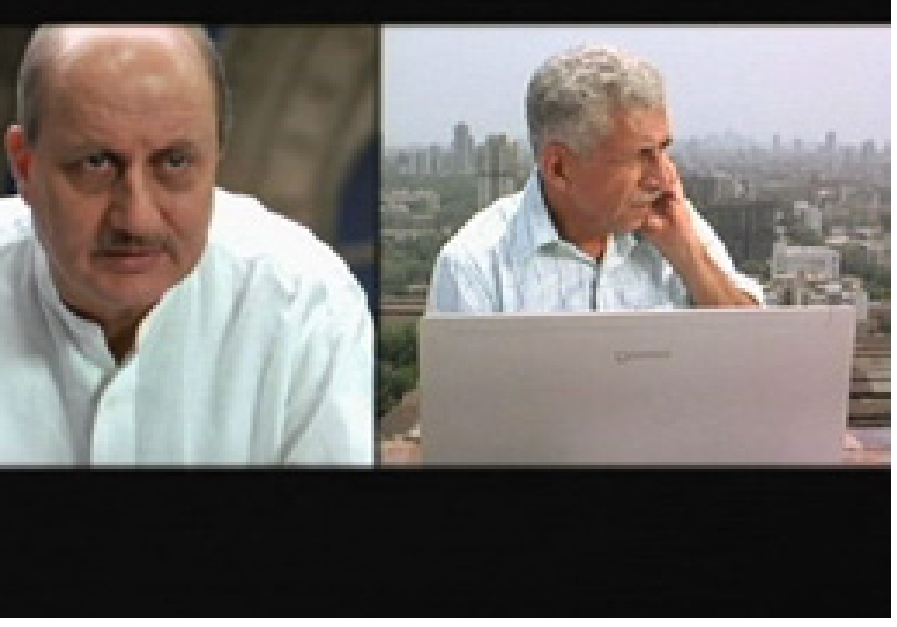

Fig. 2

As the clock ticks inexorably toward the deadline set by the protagonist, the operations of the police get even more frenzied. One of the most memorable cross-cut sequences in A Wednesday features at least three parallel lines of action: policemen Arif (Jimmy Shergill) and Jay (Aamir Bashir) travel to the aviation base with four terrorists while a sketch artist tries frantically to generate a facial profile of the caller, meanwhile, elevated far above all this action atop the skyscraper, the protagonist calmly surveys the city while drinking a beverage. His stillness and assurance are carefully juxtaposed against the desperate activities he has engendered in the besieged metropolis far below; a series of rapid shots, the pace of editing, and the pulsing music on the soundtrack underscore the urgency of the situation. The city, thus invoked, is a space of pervasive danger, chaos and potential catastrophe.

Aamir foregrounds the city of dread through somewhat different means, primarily because in this film the protagonist is immersed in the urban sensorium in a way that our vigilante from $A$ Wednesday was not. As soon as Aamir steps out of the airport, the city confronts him with all its noise, crowds and chaos. Soon after, he realizes that he and his family are in deep peril, ensnared in a web of violence, intrigue and criminal conspiracy that he can barely comprehend, let alone control. Although Aamir claims to be a native of Bombay, the city remains radical in its otherness-Bombay does not welcome him home; it constellates as a deeply threatening mélange of dense urban spaces that disturb, disorient and terrorize the hero. Aamir does not simply arrive in Bombay, he encounters it. Here again, the question of the affective generation of the filmic metropolis is of critical significance, if we understand the term as "persistent proof of a body's never less than ongoing immersion in and among the world's obstinacies and rhythms, its refusals as much as its invitations. Affect is in many ways synonymous with force or forces of encounter" (Gregg and Seigworth 2-3; emphasis in original) The body's capacity for action is also of consequence in this regard.

The film employs a virtual cornucopia of techniques to bring into being the city's dystopic geography and texture. I would like to underscore three particularly effective stylistic choices via which Bombay confronts the heroand the spectators by proxy-with its dreadful and visceral otherness: the use of selective focus, the foregrounding of crowds of strangers through blocking, and editing. In key sequences as Aamir 
tries to comply with the bhai's (literally brother, but used to denote gang leaders in Hindi cinema's vocabulary) orders, we see him ensnared in city spaces that remain defiantly inscrutable. While Aamir himself remains in crisp focus, the foreground and backgroundessentially the surrounding cityscapeis thrown out of focus. We see blurry outlines of traffic, people etc. whiz by, but not with any degree of clarity. In other words, the city is rendered indistinct as a blur of frantic motion, an affective terrain that can offer no rest, stasis or safe havens for the beleaguered hero. ${ }^{5}$ (see fig. 3 ) more familiar Bombay landmarks: the Gateway of India, Marine Drive and Victoria Terminus. Spectators echo Aamir's bewilderment and desperation, as he tries to navigate the treacherous, unfamiliar terrains of the city's underbelly: he is hopelessly lost in the warren of sprawling slums, dirty, narrow lanes and alleys, grimy, derelict exteriors and interiors, and, most importantly, amidst suffocating crowds of jostling strangers. Bombay appears as a labyrinthine maze of dark, dismal, decaying spaces that wait in anticipation to ensnare Aamir within them. These spaces resonate with what Freud called unbeimlich - the uncanny, diametrically opposed to all that can be considered familiar and the homely. ${ }^{6}$
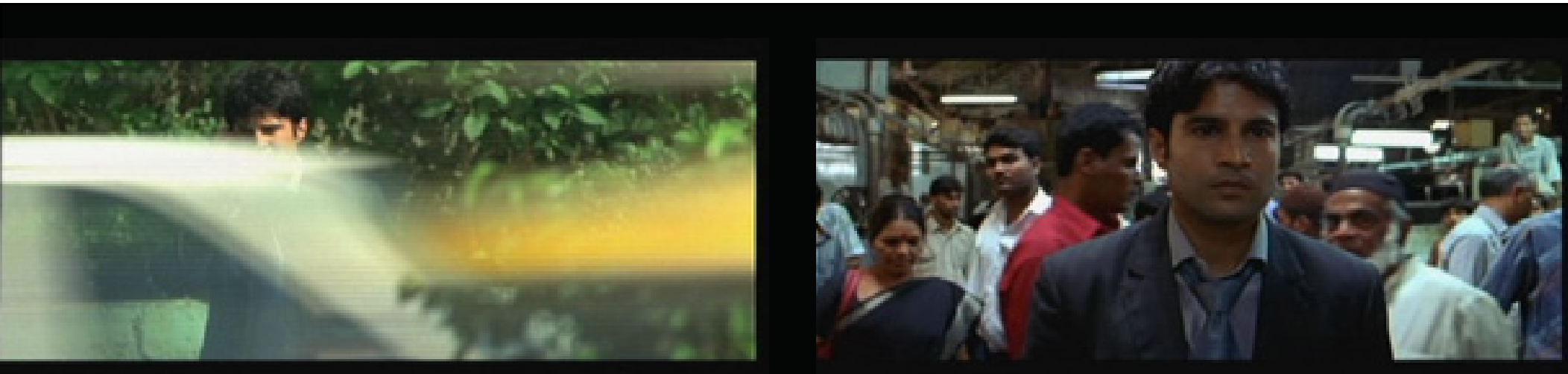

"Shattered at every step.

Fig. 3

Also crucial in amplifying Aamir's acute out-of-place-ness are the locations he is asked to traverse during his day-long ordeal. The neighborhoods of Dongri and Bhindi Bazar are hardly spaces regularly explored by Bollywood cinema; these are poor, extremely crowded, largely Muslim suburbs of the city that the film thrusts at us as spectacular counterpoints to the
Fig. 4

Aamir sticks out like the proverbial sore thumb in this landscape of urban "ruin" (Mazumdar 424), first because he is dressed in an expensive suit in jarring contrast with the poverty and squalor surrounding him, but more crucially because he is emphatically a stranger in this topos of the city as a space of danger and disenchantment. The editing of Aamir compellingly underscores 
his status as an outsider. In multiple sequences-for example, especially provocatively in the scene where he walks through the meat market ${ }^{7}$ wide shots of the hero trapped amidst crowds hurrying through the city are rapidly juxtaposed against big close ups of faces, presumably observing his every move from the vicinity. We are never given a spatial context for these faces, most of which look watchful, sinister, sentient; we never know how close or far away these disembodied people are from Aamir, amplifying our sense of disorientation and dislocation. (see figs. 4, 5 and 6). The point-of-view mobile shots ensure that when these faces look at him, they also look at us. ${ }^{8}$ Some sequences juxtapose slow motion shots of crowds, faces and feet; masses of unfamiliar bodies push, shove and jostle Aamir as he desperately hurries to do the bhai's bidding. The sporadic use of a hand-held camera also underscores our sense of participation in this sequence. In a radical revision of Bollywood's typical representations of good-hearted, plebian city-folk, the pressing multitude never offers comfort or succor to the hero; the crowds remain inscrutable, apparently either hostile or simply indifferent, and, oppressively close, heightening Aamir's acute sense of being claustrophobically hemmed in. And, the sense of ever-present threat is always overwhelming amidst crowds, especially because the press of unruly, chaotic bodies also includes the bhai's minions and agents, ensuring his constant omniscience.

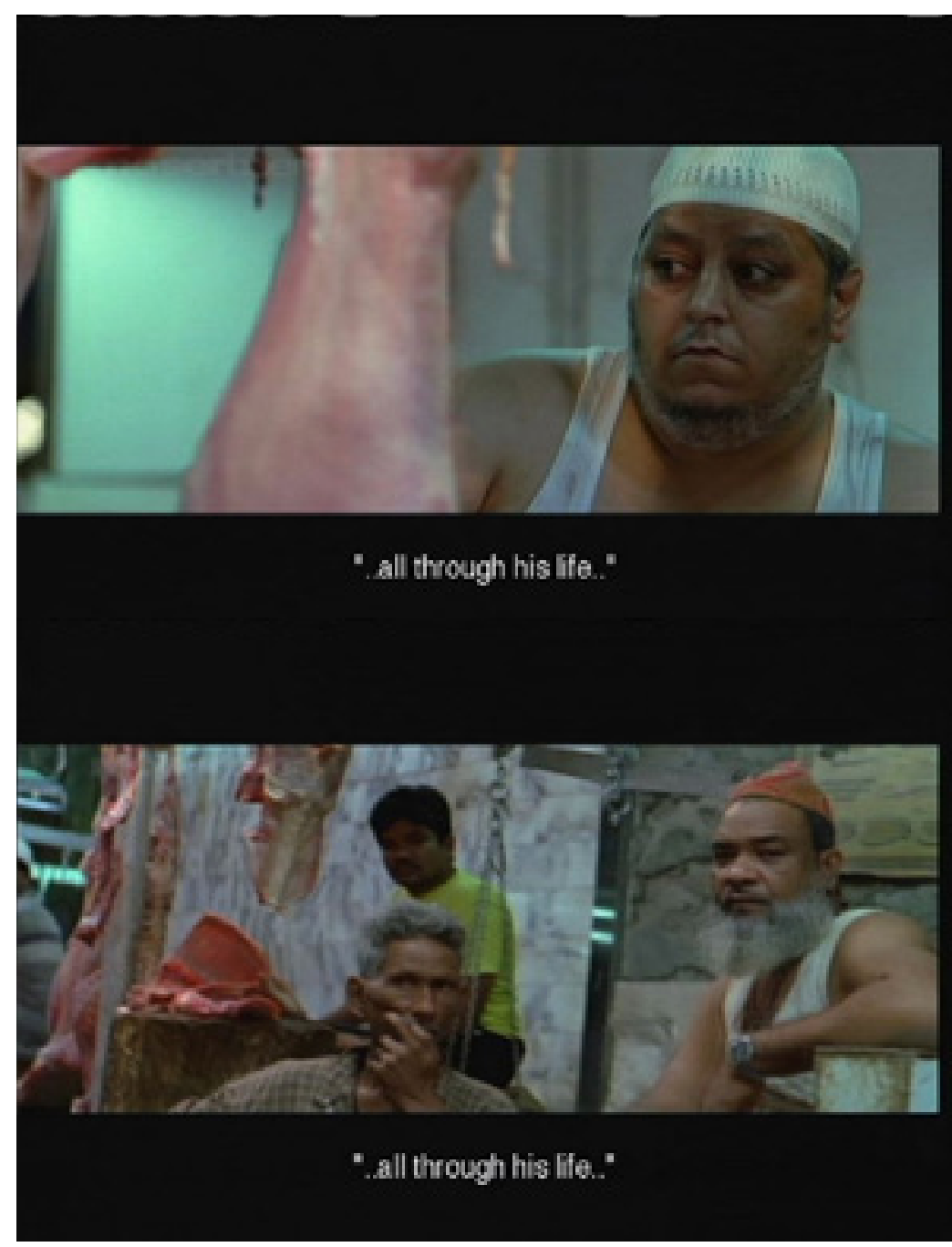

Fig. 5, Fig. 6

\section{Panopticon, Synopticon and the City of} Surveillance

The dreadful city in both $A$ Wednesday and Aamir is also, foundationally, a city of surveillance. Each film envisages Bombay via distinct and varied regimes of visibility: in the former, the protagonist surveys the city, unseen, from his rooftop perch, in the latter Aamir is always under scrutiny by visible and invisible eyes. Both texts also foreground modern communication devices, most ubiquitously the mobile phone which connects disparate spaces 
and actors in the drama of suspense and violence.

Following Michel Foucault's (1977) seminal elaboration of Jeremy Bentham's 1785 disciplinary model of the Panopticon, the trope has come to be pervasive in the field of surveillance studies. In spite of its limited purchase in engaging with the mind-boggling array of data gathering technologies used currently by statist authorities and corporations, the panoptical model is in fact quite resonant with the manner in which A Wednesday maps the city of Bombay as a series of visible and invisible zones of access and control. ${ }^{9}$ First, the film simultaneously fetishizes latest technological devices and renders them everyday. The "stupid common man" has amassed a vast array of computerized and network devices on the rooftop and, as mentioned above, he calmly informs Rathod that in the era of the internet, it is ridiculously simple to access technologies of violence. (see fig. 7) Once again, we are confronted by the dialectics of ordinariness/extraordinariness of the vigilante citizen, and, the same dialectic informs the film's representation of informational technology and its relationship to potential violence. If a "common man" can create and detonate a dozen bombs across Bombay, then the law enforcement apparatus is rendered completely impotent in the current era of pervasive electronic competence. The age of information is both abilifying and debilitating; informational regimes can just as easily be deployed to plan and execute violence as to prevent it. In Bombay-the city besieged by terror-the former has historically triumphed over the latter. A Wednesday also underscores this discrepancy in terms technological/informational competence between the state and the vigilante/terrorist.

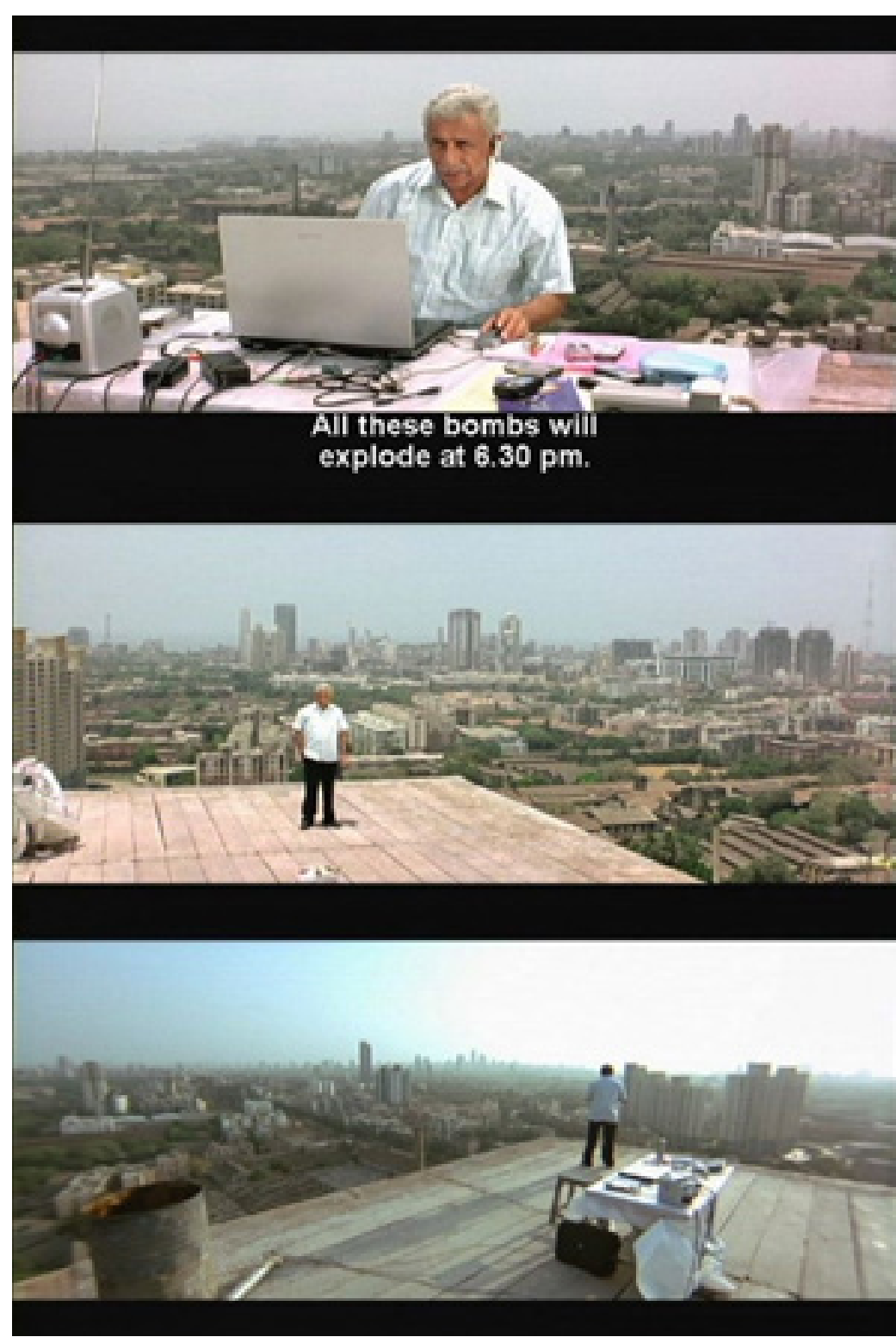

Fig. 7, Fig. 8, Fig. 9

Vision-seeing/observing/surveillance as a metaphor for power-is also granted to the protagonist via the camerawork of the film. In several key sequences, the 
protagonist is framed against Bombay's cityscape, and a number of 360 degree tracking, panning and crane shots, present the city as his domain (see figs. 8 and 9). This is a vista of urban geography that he controls through the power of vision: "The panoptic urge is to make everything visible; it is the desire and drive towards a total gaze, to fix the body through technique and to generate regimes of self discipline through uncertainty" (Lyon 44). The absolute gaze of the protagonist is ironically reinforced by the fact that he is both intimately linked to these spaces, and, simultaneously loftily removed from them. Rahul Mukherjee provides an excellent description of these sequences of surveillance, visibility and control in A Wednesday:

If terror indeed thrives on information, of which it must deprive the victim, the deceptive "stupid common man" garners news through Naina Roy's news channel and dodges the police's attempts to track down his location by switching SIM cards and using rerouted mobile phones. He sees the city through television, he does not seek his enemies on the streets of the city. His ensuing telephonic duel with the commissioner begins to resemble Paul Virilo's conceptualization of international warfare as an "optical confrontation" which involves "seeing," "forseeing" and "not being able to see", and "where winning is trying to keep the enemy in constant sight" (244).
The state's relative incompetence in terms of informational technologiesalthough we also witness urgent counter-surveillance attempts in the war room and the use of a hacker-is also conveyed through the vigilante's splendid, singular stillness, starkly in contrast with a "series of fast paced, sharply edited shots of the commissioner pacing the police station, directing his officers over the phone as they frantically try to detect bombs in crowded malls and train stations" (Mukherjee 244). As mentioned above, the technique of cross-cutting enables the audience not only to witness parallel lines of action occurring simultaneously, but also to appreciate the vastly different affective domains occupied by the state and the protagonist.

Aamir imagines the dreadful metropolis through an economy of visibility that can be understood in exact opposition of the panoptical model of A Wednesday. Here, the many seen and unseen eyes surveil the one beleaguered hero Aamir-a reverse configuration that Thomas Mathiesen has famously called the Synopticon (1997). Aamir charts the spaces of Bombay not only through cartographies of surveillance but also renders it completely paranoid. Notably, for Freud (2003), paranoia is a pathological state intimately connected to the fear of being looked at. Aamir's terror escalates not only as he understands the nature of the scrutiny he is under-an entire city is operating as a well-coordinated machine, the omniscient eyes and ears of the Big Brother-but also because 
his life has been reduced to a data mine already available to the terror network. The bhai calmly recounts every detail of Aamir's existence to him, reinforcing the power of surveillance and data gathering as a process that has begun even before the film commences. Because it uses surveillance as narrative content, Aamir can be understood as a film about regimes of visibility. Dozens of high-angle shots in which we see Aamir meandering through crowded lanes and mohallas (neighborhoods) render him dwarfed and vulnerable, but strictly visible at all times; these bird'seye shots are not necessarily attributed to specific observers, they remain free floating point-of-view shots without a specific viewing subject-a technique that reinforces the impression of the entire city as a terrifying scopic regime. Potentially every shot of Aamir negotiating the city-maze could be a carefully truncated point-of-view shot, a technique that makes every scene watchful, sentient. Occasionally, we share Aamir's fearful gaze as he looks around him, watches faces that press in on all sides, and, people standing in balconies and windows of the derelict buildings that tower over him (see fig. 10). The editing underscores this paranoid relationship to the city as quick cuts give us brief, disembodied glimpses of faces that may or may not belong to the bhai's many 'informers.' The ever-present mobile phone-in the film's visual universe almost everyone constantly speaks into these-also creates a domain of surveillance and the constant transmission of information; whatever Aamir does, whether he complies or disobeys the spectral commands, is instantly conveyed to the bhai (see fig. 11). The city and the citizens-all of whom in this paranoid framework become by default the bhai's minions-function as a networked totality: a web of information that surrounds Aamir and holds him enmeshed in its invisible embrace. The bhai, thus, rules over the city through his control of visual/aural terrains; his absolute authority is ensured by absolute scrutiny.

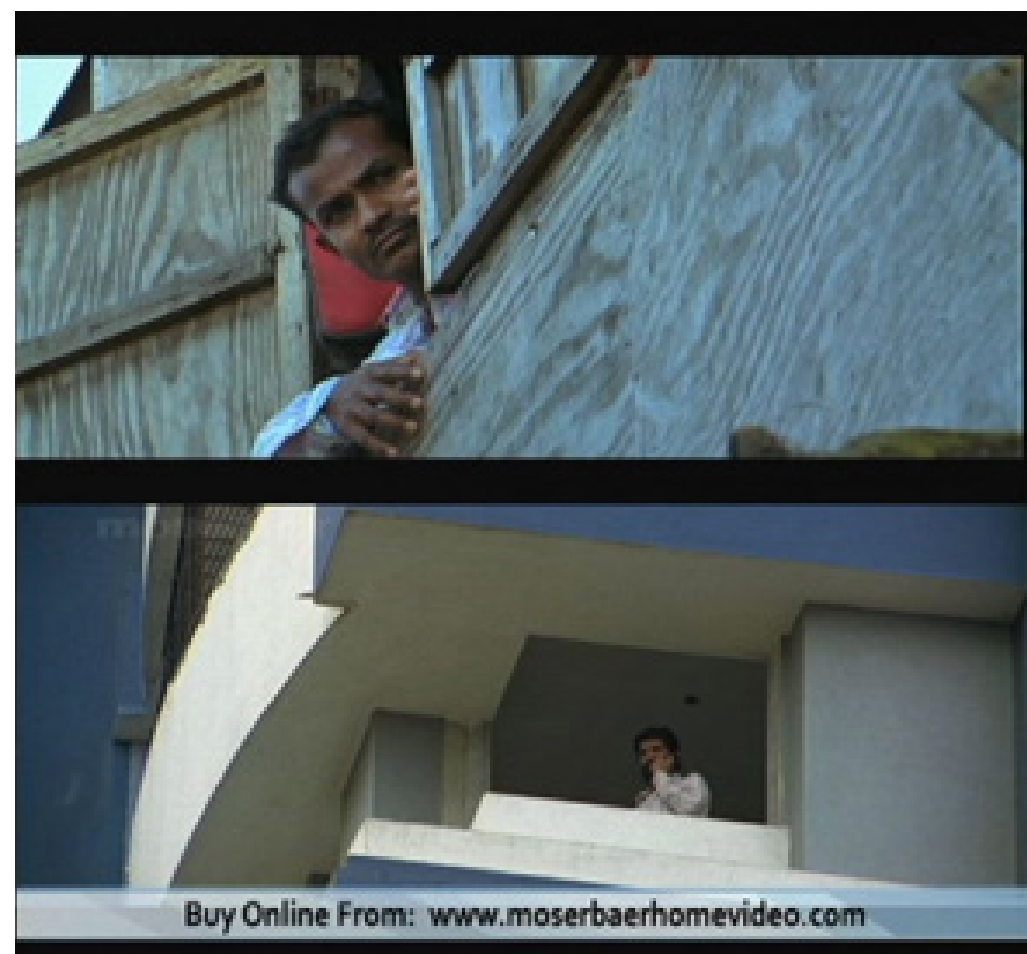

Fig. 10, Fig. 11

Hindi popular cinema's romance with the city of Bombay has undergone several distinct iterations; through all the phases however, the city has always offered spaces of redemption and rehabilitation-spaces of respite, sanctuary and solace for filmic protagonists. After a series of terror attacks in recent decades and following 
massive transformations in the socioeconomic and political spheres in India, the city is no longer figurable only as a liberating space of modernity and globality. Recent Bollywood cinema now interrogates its relationship with India's most iconic metropolis through narratives of death, destruction and actual or potential catastrophe. Films such as Aamir and A Wednesday, among many others, provide us with a privileged point of entry into the cinematic metropolis as constitutively and foundationally transformed by a new era of globalization and terrorism. Bombay-once the beloved metropolis of Bombay cinema, the site where the dreams of the nation were most compellingly articulated, where dreams could sometimes be realizedhas come to stand in for failure of the modern state in India. Bombay has become a dreadful, dystopic, cinematic nightmare-a metropolitan ruin.

\section{Works Cited}

Biswas, Moinak. "Shaharer Chitralipi." In Baromas (32) Saradiya. Kolkata:

Baromas, 2012. 219-228. Print.

---."Mourning and Blood Ties: Macbeth in Mumbai. In Journal of Moving Image." (5) 2006. Web. <doi: http://www.jmionline.org/ film_journal/jmi_05/article_04.php>.

Deleuze, Gilles. "Postscript on the Societies of Control”. In October (59) Winter 1992. 3-7. Print.

Foucault, Michel. Discipline and Punish: The Birth of the Prison. New York: Vintage, 1977. Print.
Freud, Sigmund. The Uncanny. New York: Penguin Classics, 2003. Print.

Lyons, David. "9/11, Synopticon and Scopophilia: Watching and Being Watched." InHaggerty and Ericson, eds. The New Politics of Surveillance and Visibility. Toronto: University of Toronto Press, 2006. 35-54. Print.

Massumi, Brian. "The Future Birth of the Affective Fact: The Political Ontology of Threat." In Gregg and Seigworth, eds. The Affect Theory Reader. Durham: Duke University Press, 2010. 52-70. Print.

Mathiesen, Thomas." The Viewer Society: Michel Foucault's 'Panopticon' Revisited.” In Theoretical Criminology 1 (2) (1997). 215-34. Print.

Mazumdar, Rnajani. "Spectacle and Death in the City of Bombay Cinema." Prakash and Kruse (Eds.), The Spaces of the Modern City: Imaginaries, Politics, and Everyday Life Princeton: Princeton University Press, 2008. 401-432. Print.

Mehta, S. Maximum City: Bombay Lost and Found. New York: Vintage Books, 2005. Print.

Mukherjee, Rahul. "A Reply To Terrorism on a Wednesday: A Citizen Vigilante's Prescriptions for Governing Terrorism." In Sarai Reader 08: Fear. Delhi: CSDS, 2005. 242-247 Print..

Prasad, M. "Realism and Fantasy in Representations of Metropolitan Life in Indian Cinema." Kaarsholm, ed. City Flicks: Indian Cinema and the Urban Experience. (pp. 83-99). Kolkata: Seagull Books. Print.

Seigworth, Gregory and Gregg, Melissa. "An Inventory of Shimmers." Gregg and Seigworth, (." eds. The Affect Theory Reader. Durham: Duke University Press, 2010. 1-25. Print.

Tanvir, Kuhu. "Myth, Legend, Conspiracy: Urban Terror in Aamir and Delhi 6." In Sarai Reader 08: Fear. Delhi: CSDS, 2008. 248253. Print. 
Vasudevan, Ravi. "The Exhilaration of Dread: Genre, Narrative Form and Film Style in Contemporary Urban Action Films." In Sarai Reader 02: The Cities of Everyday Life. (Delhi: CSDS, 2002. 58-67. Print.

\section{(Endnotes)}

1 In Biswas's reading, this new kind of "naturalism is fundamentally different from, say, a neorealist film where vision could flow from the sparse everyday objects to the natural horizon with relative ease. A surfeit of objects is offered to the eye. The underworld, seen in this perspective, is a seemingly endless study of faces, gestures, speech and action, built upon the modes of humdrum urban street life and subaltern living made familiar primarily through television.” (online)

2 Rahul Mukherjee has noted that ironically, bomb blasts accompanied the release of $A$ Wednesday in several cities across India (243).

3 While this history of violence informs the films' temporal imagination of Bombay, the plots adhere to strict deadlines; both films feature multiple lines of action which move in a linear fashion toward the climax. The plots remain faithful to the clock, the rendition of the city as an affective domain does not. In other words, here I am making a crucial distinction between plot-time-which operate under unyielding deadlines in each case-and the temporal figuration of the city of Bombay.

4 What we have here is an excellent example of what has been called "haptic visuality" in recent media theories-a way of viewing that engages multiple senses. Aamir's images constantly challenge the spectator to mobilize our senses-to see, touch and smell the nightmarish world that Aamir finds himself trapped within.
5 Kuhu Tanvir also comments on the film's lack of domestic spaces and homeliness: "Aamir is the only upper-class moderate Muslim the film has, and it is therefore worth noting that his private space is not shown almost at all, except for one short, imagined scene when he recalls calling home and speaking to his family. When compared to the way in which other, public, apparently non-secular spaces are mapped in the film, this scene, which is barely a few seconds long, can be easily forgotten (249).

6 Aamir's return with the red suitcase through the slaughterhouse is also shot with the foreboding song, "Haara Haara" pulsing on the soundtrack, enforcing Aamir's acute sense of entrapment.

7 Moinak Biswas, for example, has argued in a recent essay that Aamir's invocation of the uncanny hinges on the manner in which the screen "looks back" at us. When the seen-in this case the dense, diegetic world of the filmreturns our gaze, a deep sense of discomfiture is generated. (226)

8 Gilles Deleuze's conceptualization of "societies of control" offers another valuable framework for understanding the imprecise, flexible and occluded nature of power in films like Aamir and A Wednesday. According to Deleuze, we have now moved from what Foucault's calls disciplinary societieswhere laws are represented by the enclosed and confined spaces of the prison, factory, hospital, etc.- - to a more open, dispersed and free floating form of control in late capitalism, that is no less unforgiving. Under the aegis of the global market control is "continuous and without limit" while the individual is merely a "dividual" - "undulatory, in orbit, in a continuous network" (6). Two aspects of Deleuze's argument are especially pertinent to the present discussion-the simultaneous ubiquity and dispersive nature of power, and, the impossibility of dodging its constantly mutating operations. The pervasive nature of control is tellingly apparent in, for example, Aamir's futile attempt to slip past the network of mobile phones that constitutes the informatic straightjacket of the city. It is of little consequence in this respect if the state surveils the individual or non-state actors. In the current media ecology, the individual is always strictly within network. 
Meheli Sen is Assistant Professor in the Department of African, Middle Eastern, and South Asian Languages and Literatures (AMESALL) and the Cinema Studies program at Rutgers University. Her primary research area is post-independence popular Hindi cinema, commonly referred to as 'Bollywood'. She is especially interested in how the filmic registers of genre, gender and sexuality negotiate specific moments in India's troubled encounters with modernity and more recently, globalization. Sen's work has been published in journals such as The Journal of the Moving Image and South Asian Review, as well as in the edited anthology Bollywood and Globalization: Indian Popular Cinema, Nation, and Diaspora. She is co-editing an anthology titled Figurations in Indian Film, forthcoming from Palgrave-Macmillan. Her current research engages 'B' genres, particularly horror, in the larger rubric of the Bollywood system.
Meheli Sen est professeure adjointe dans le département des langues et littératures de l'Afrique, du Moyen-Orient et de l'Asie du Sud (AMESALL), ainsi que dans le département d'études cinématographique à l'Université Rutgers. Son domaine de recherche principal est le cinéma populaire hindi de l'aprèsIndependence, qu'on appelle habitualement "Bollywwod ". Elle s'intéresse à la manière dont la représentation du genre, du sexe et de la sexualité dans le cinéma permet de négocier des moments particuliers du rencontre difficile de l'Inde avec la modernité et la globalisation. Sen a publié dans « The Journal of the Moving Image » et "South Asian review ». Elle a également édité l'anthologie Bollywood and Globalization: Indian Popular Cinema, Nation and Diaspora. Elle collabore actuellement à la révision d'une anthologie intitulée Figurations in Indian Film, à paraître chez PalgraveMacmillan, et elle mène des recherches sur les genres « B », surtout l'horreur, dans le système Bollywood.

Copyright Meheli Sen. This article is licensed under a Creative Commons 3.0 License although certain works referenced herein may be separately licensed, or the author has exercised their right to fair dealing under the Canadian Copyright Act.

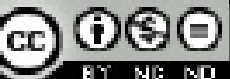




\title{
MY LAST FOUR MINUTES ON PRINCE WILLIAM STREET
}

\section{ADRIANA ONITA}

\author{
12:06 \\ climbing out of my window \\ to practice kissing on a gargoyle
}

\author{
12:07 \\ bunching over harbour, city, \\ his gaping mouth, tongue protruding \\ fresh dulse smell wafts onto his lips \\ salty ocean stuck to his stone-flesh \\ 12:08 \\ foglover, my hybrid pagan god, \\ with your ghastly, gothic stare \\ surely if I do not blush for you \\ I should at least regret \\ what I have spent on you

$$
\text { 12:09 }
$$ \\ a stone tooth in my mouth \\ 12:10 \\ the last sign of our love affair
}




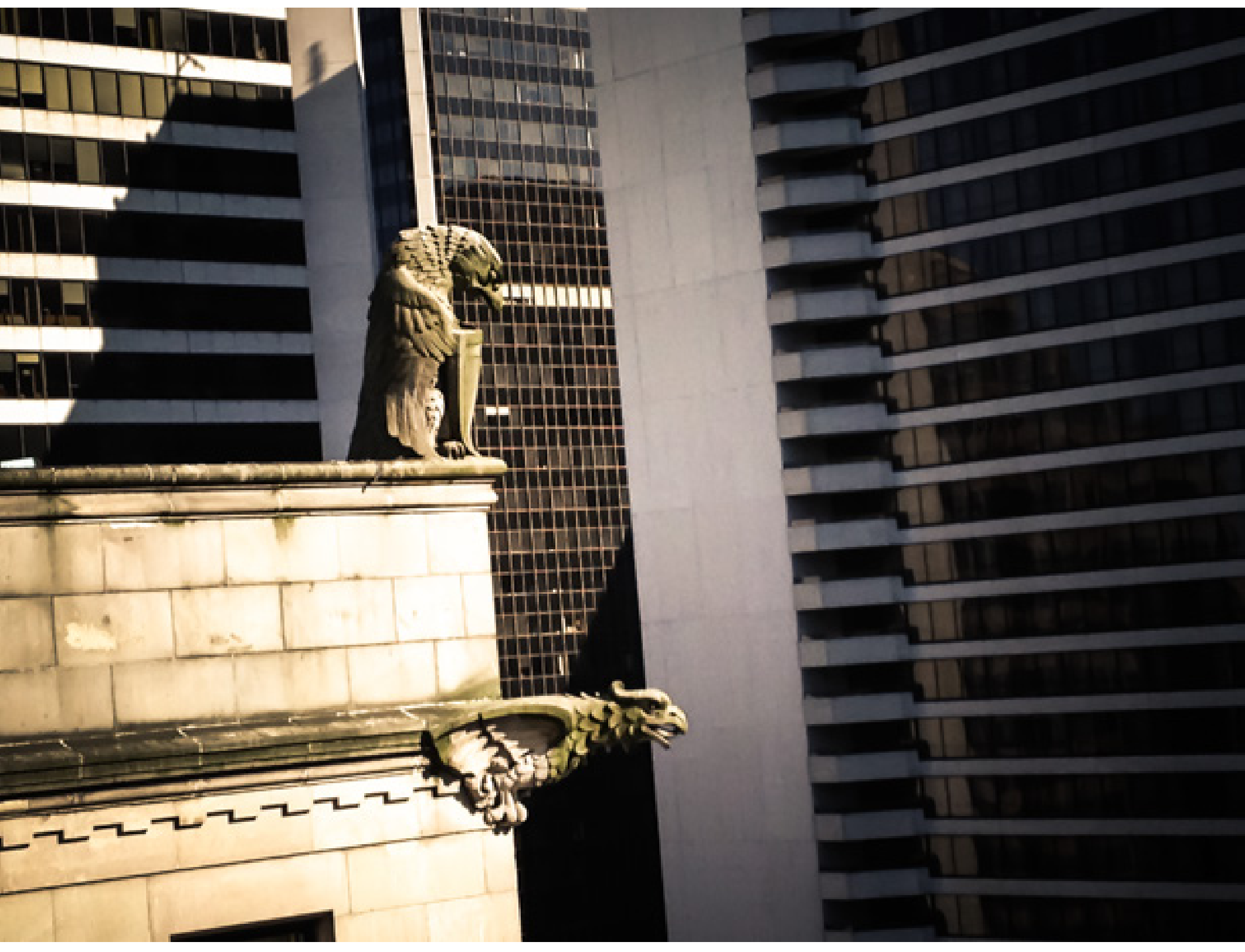

IMAGE - ELENA SIEMENS 


\section{HORROR AND THE BODY UNDERSTANDING THE REWORKING OF THE GENRE IN MARINA DE VAN'S DANS MA PEAU/IN MY SKIN (2001)}

\section{ROMAIN CHAREYRON}

This article explores how Marina de Van's confrontational representation of the human body, in her film Dans ma peau/In my Skin (2001), should be understood as a reinterpretation of certain major themes in the horror genre. More specifically, I examine how de Van's mise-en-scène borrows from the genre of horror, both on a visual and a technical level, to deconstruct the meanings initially attached to the representation of the body in pain found in horror's narratives. I argue that a close analysis of the textural properties of the image allows for a reappraisal of the onscreen presence of the wounded body, this body departing from horror's straightforward visual regimen, to open up a space for the character's subjectivity to emerge. I also posit that the use of the close-up on images of blood and scars, while being reminiscent of horror's treatment of the body, becomes a vehicle for the unleashing of the character's unmediated drives to explore her own flesh and to reach a new level of selfawareness.
Cet article propose de considérer la représentation confrontante du corps humain par Marina de Van dans son film «Dans ma peau " (2001) comme une réinterprétation de certains thèmes centraux au genre de l'horreur. Plus concrètement, on montre que Van emprunte au genre de l'horreur sur les plans visuel et technique afin de déconstruire les significations liées à la représentation du corps souffrant dans le récit d'horreur. On soutient qu'une analyse approfondie des caractéristiques relatives à la texture de l'image permet une réévaluation de la présence sur l'écran du corps blessé, à partir du régime visuel de base du récit d'horreur. Cette réévaluation crée un espace où la subjectivité du personnage peut apparaître. La représentation en gros plan du sang et des cicatrices rappelle le traitement du corps dans le cadre du genre de l'horreur. On suggère ultimement que cette représentation devient un instrument pour que le personnage qui déchaîne un désir spontané d'exploration de sa propre chair afin d'atteindre une plus haute conscience de soi. 
From the moment it was released, Marina de Van's directorial debut Dans ma peau (In my Skin, 2001) has been praised as the shining example of French cinema's contentious new trend of cinéma $d u$ corps. ${ }^{1}$ Mainly interested in visceral and discomforting depictions of the human body, cinéma $d u$ corps designates "[...] a spate of recent French films that deal frankly and graphically with the body and corporeal transgressions [and] whose basic agenda is an on-screen interrogation of physicality in brutally intimate terms" (Palmer, Brutal Intimacy 57). With its uncompromising portrayal of Esther [Marina de Van], a young and successful woman whose life spins out of control when she begins to explore her body by way of self-mutilation and self-cannibalism, the film undoubtedly echoes some of cinéma $d u$ corps' main aesthetic and narrative concerns in its desire to "[push] screen depictions of physicality to unwelcome limits, raising basic issues of what is acceptable onscreen" (Palmer, "Style and Sensation in the Contemporary French Cinema of the Body" 22). If the film's unflinching representation of physicality warrants its affiliation with this new cinematic trend, it is essential to understand where this representation originates, in order to appreciate the complex visual regimen it creates as well as its impact on the images themselves and how we respond to them.

For the most part, the film's uncompromising treatment of the body in pain has been analyzed in the light of what shaped up to become cinéma $d u$ corps' "manifesto," including topics such as:
[...] dispassionate physical encounters involving filmed sex that is sometimes unsimulated; physical desire embodied by the performances of actors or nonprofessionals as harshly insular; intimacy itself depicted as fundamentally aggressive, devoid of romance, lacking a nurturing instinct or empathy of any kind; and social relationships that disintegrate in the face of such violent compulsions (Palmer, Brutal Intimacy 57-58).

The pitfall of this analysis is that it fails to acknowledge the film's most significant aesthetic achievement, namely, how it uses the horror genre as a foundation for its deeply intimate and profoundly disquieting representation of the human body. However, the references to horror never appear as a simple gimmick within the film, as the latter does not rely on the shock value that comes with the excessive display of blood or dismembered bodies, as does traditional horror cinema. My proposal is that, what defines the film's aesthetics is its constant reworking of the various visual and/or technical components of horror. In so doing, the film attempts to observe how these components can operate outside the genre's preestablished framework and generate new ways of understanding images of the body.

This article will examine how the film deconstructs horror's highly codified visual regimen in order to open up a space where the transformational capacities of the body can be fully expressed. By analyzing specifics of the mise-en- 
scène, such as the textural properties of the image and the technique of the close-up, I will argue that the narrative deconstructs the horror genre, both in its themes and its visual treatment of the body, to position the latter within a discourse of empowerment whose aim it is to challenge social norms of behavior and beauty.

"Since, for Esther, it is first and foremost a personal quest, each scar has a different meaning, which is visually conveyed by its shape and its position on the body" (Rouyer, "Style and Sensation" 29; my translation): these words come from Marina de Van herself, explaining the meaning attached to Esther's acts of self-mutilation and self-cannibalism. I chose this quotation as the main premise of my analysis, for it conveys the dual nature at the heart of the acts depicted within the narrative; if they first recall the horror genre through their explicit representation of a wounded body, the meaning of such graphic acts has to be understood as going beyond the simple desire to present us with disquieting images of violence and torture. Skin, in de Van's film, becomes the ultimate way for the character to reclaim her own body, so that flesh - the surface - gradually becomes an inscribable surface where Esther's inner turmoil and feelings - the inside - find their visual transcription.

The semantic instability of the skin is established through the opening shots of the film, with a close-up of Esther's leg, as she is seen sitting at her desk, typing on her computer. The uncanny emerges out of this familiar setting through the combined work of the lighting and the editing. The former works to bring out the materiality of the flesh, as the use of a chiaroscuro intends to show the ruggedness and the imperfections of the skin. ${ }^{2}$ In so doing, the film refuses to aestheticize the body, but instead wishes to reveal it in all its raw corporeality. Our initial discomfort is reinforced by the editing, as there is no tracking shot on the leg that would allow us to mentally "attach" it to Esther's body. Instead, the editing cuts to a close-up on Esther's face, as we see her scrutinizing the screen of her computer. Body and mind are clearly disconnected in this scene, and strangeness arises from the combined work of the close-up and the abrupt editing, as they "[...] convert a concrete entity into a decontextualized immobile surface with motor tendencies that expresses an affective quality/power" (Rogue 79). The conjoined work of the mise-en-scène and the editing serves to highlight the raw materiality of the flesh and to convey the idea that the body has a life of its own that cannot be subjected to the power of the mind. This foreshadows the shift that will occur when Esther will let her uncontrolled impulses take precedence over social rules of conduct by damaging her body, ${ }^{3}$ alienating her friends and loved ones in the process. By isolating the leg and giving the spectator an acute sense of the density of the flesh, the mise-en-scène emphasizes the textural significance of the skin. This visual device will evolve to become a central element of the representation, as we get 
to see Esther's leg covered with blood and scars, indicating the different stages of the young woman's exploration of her own body.

This initial work on the inherent strangeness of the skin is reminiscent of one of horror cinema's founding concepts that consists in revealing, through purely cinematic means, the unfamiliarity that lies at the heart of seemingly banal objects and events:

It is as if the way of presenting events would reveal the true [...] meaning of a gesture or a situation that would otherwise appear banal. This is not achieved by connecting these events to the ordinary meaning they are endowed with in everyday life, but by incorporating them within the new context of a possible world that gives them a new significance [...] (Dufour 29; my translation).

The narrative starts to question the meaning of the body and its on-screen presence through a defamiliarization process that forces us to see something common (a leg) in an unfamiliar way. Our questioning is intensified by the technique of the split-screen, which consists of showing two images simultaneously and separately on the screen. Each screen displays various urban settings (a beltway, offices) and random objects from everyday life (pens, scissors). This technique raises our awareness of the skin as being a transformable surface, and it does so by introducing the notion of "cutting" as a founding element of the representation.
This is first conveyed through the technique of the split-screen that establishes a parallel between the "skin" of the film - the reel - and the actual human skin - the epidermis - that Esther will subsequently cut. Then, the combined work of the shooting scale and the editing gives a similar significance to the objects present within the shots and Esther's leg. Consequently, we associate the close-up on the pair of scissors with the shot of the leg, the latter emerging as a surface that can be manipulated and transformed and whose significance always has to be redefined. In so doing, the representation hints at the fact that Esther's body is first and foremost defined by its potential for transformation.

If the first shots of the film use the image of the yet intact leg as a visual motif for the uncanny presence of the body on-screen, the narrative then unfolds a series of images that focus on the injured limb in order to represent the different stages pertaining to Esther's physical transformation. If these scenes might appear to tighten the connections between the film and the horror genre, they first and foremost encapsulate the narrative's intricate reworking of some of the genre's most significant topoi. The scene at the doctor's office, which takes place soon after Esther initially injured her leg at a party, constitutes an interesting example of how the film proceeds to retain some of horror's visual codes (i.e. the focus on the blood and the open wounds) while disrupting their initial meaning. In this scene, Esther's leg is perceived 
through a series of close-ups that reveal each minute detail of the gash, allowing us to see the deep scars that run along the leg, the clotted blood and the surgical suture sewn by the doctor. The unflinching display of the damaged flesh echoes the modus operandi of traditional horror narratives, since "[it] [horror cinema] corresponds to the negation of the out-of-frame and the elided. The camera invests the former so that it can fully dwell on images of horror, while the latter is denied so that death and physical pain can be felt in their duration" (Rouyer, "Entretien" 161; my translation, my emphasis). If this scene makes the body in pain the central element of the representation, it is necessary to move beyond the first impressions of shock and disgust in order to understand the raison d'être of such a visual regimen. To do so, we need to observe how the film denies the spectator visual mastery over the representation and chooses to rely on the textural significance of the image by switching from an optic to a haptic mode of vision. By unsettling our sense of perception and heightening our sensory investment within the narrative, the film disrupts any uncomplicated connection between its imagery and the horror genre, as it allows the cinematic body to exist and generate meaning beyond a normative frame, so that the character's subjectivity regulates the flow of disturbing images we are presented with.
When optic vision is based on rationality and verisimilitude between the onscreen world and the realm of human experience, haptic vision breaks this contract to pull the audience into a world ruled by feelings and sensations, rather than by human logic and the desire of mastery through the gaze. As Martine Beugnet aptly points out: "[w]hereas optic images set discrete, self-standing elements of figuration in illusionistic spaces, haptic images dehierarchise perception, drawing attention back to tactile details and the material surface where figure and ground start to fuse" (65-66). We observe a similar shift in the scene at the doctor's office; we first see Esther through a long shot that establishes a clear separation between her body and that of the spectator. Then, the different images of the wounded leg being palpated and stitched are shot in a series of close-ups from a subjective camera angle, giving the spectator the illusion of personal experience (see figs. 1 and 2).

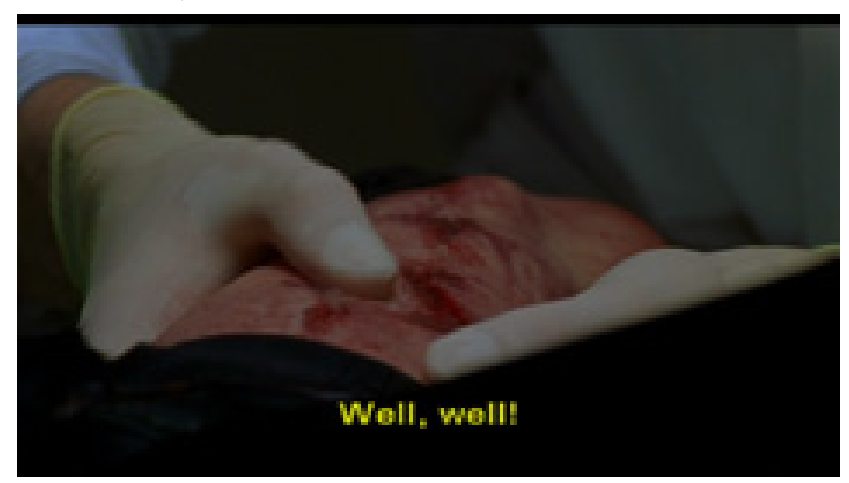

Fig. 1 "Haptic vision and spectatorial involvement." 


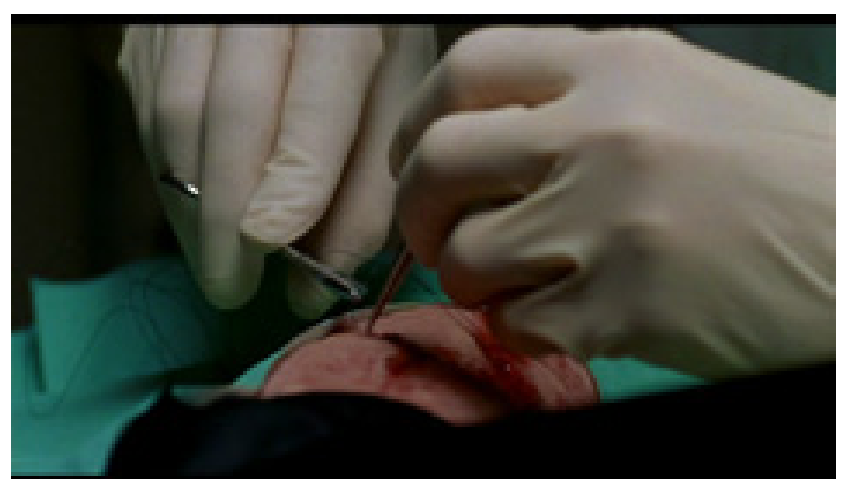

Fig. 2 "Flesh as malleable surface."

By immersing the spectator into a world of raw sensations, the mise-enscène heightens our sensory response to the images on-screen and blurs the boundary between observer and observee, forcing us to abandon our position as passive onlookers to become active participants within the fiction. Through the combined use of the close-up and the subjective camera angle, we are not simply confronted with disturbing images of the scars on the leg, as we literally come to identify with Esther. A fusion operates between spectator and character, whose aim it is to intensify the audience's physical involvement within the fiction. By relying on visual strategies that generate "[...] sensory impressions that stylistically outrun and strategically overwhelm its narrative" (Palmer, "Brutal Intimacy" 86), the film asks us to feel Esther's pain and confusion in our own body. This corporeal and emotional investment takes precedence over the sheer disgust that usually arises at the vision of injured bodies in traditional horror cinema and, as a result, forestalls any moral judgment on our behalf.
It is by enhancing the textural properties of the image and the feeling of touch within the representation that this physical involvement between the audience and the image is made possible. In so doing, the film symbolically bridges the gap that separates the spectator from the fictional space:

The viewer's skin and the film's skin allow a fleeting, incomplete kind of access to the other, which is pleasurable in its impermanence and incompletion. Their role at and as the surface of a body, as texture that both reveals and conceals, marks the fundamental affinity between the human's skin and the film's skin (Barker 49).

To achieve this, the different shots of the injured leg play on a series of opposite sensations linked to touch and the materiality of the flesh, where the smooth texture of the intact leg echoes the scars that cover the wounded one, and the red color of the bloodied leg is opposed to the pallor of the other. In the scene at the doctor's, the injured leg rather resembles a rugged landscape, and the gash can be assimilated to a deep geographical fissure, so that we are moved beyond the initial shock of horror to invest the representation and to physically experience the pain and the potential for transformation that arises out of the damaged flesh. Through the establishment of haptic vision, flesh becomes a malleable element that can be touched, cut open and stitched up in order to create something new, whose meaning cannot be intellectualized, but only felt. Any idea of moral judgment 
is deterred, as our corporeal and emotional investment takes precedence over the sheer disgust that usually arises at the vision of injured bodies in traditional horror cinema, which enables us to share Esther's sphere of experience on a deeply intimate level.

Building on this pivotal scene, the film subsequently documents Esther's escalating practice of self-cutting, the acme being reached when the young woman locks herself in a hotel room to cut and eat pieces of her skin. Whereas the scene at the doctor's office represented Esther's rather detached reaction to the vision of her wounded body, the scene taking place in the hotel room pictures Esther willingly cutting herself and transforming her own body, the latter moving from a passive form to an active force. This scene echoes horror cinema's symbolic use of the close-up, as the camera focuses on Esther's upper body, while blood from her wounds is dripping on her face. I will observe how the film uses the technique of the close-up, combined with the presence of blood and wounds, to transcribe Esther's inner urges, so that the closeup departs from the ideas of constraint and limitation usually attached to it and becomes the privileged mode of expression for Esther's uncharted exploration of her own body.

The technique of the close-up, associated with images of dismembered bodies, gaping wounds and blood is emblematic of a visual regimen whose significance can be traced back to horror and, more specifically, the subgenre of gore cinema (Rouyer, Le Cinéma gore 162). Despite its unquestionable ties to the horror genre, the representation of the body in de Van's film is not so much interested in those constituent topoi of horror that are the excessive and elaborate display of blood and wounds, as it wishes to unleash the potential for transformation and freedom that comes out of such extreme experimenting. To understand how the representation privileges the transformational power of the body over a sensational depiction of the damaged flesh, it is necessary that we focus our attention on the significance of Esther's body movements and, more specifically, on the action that consists in self-consciously harming herself (see Figs 3 and 4).

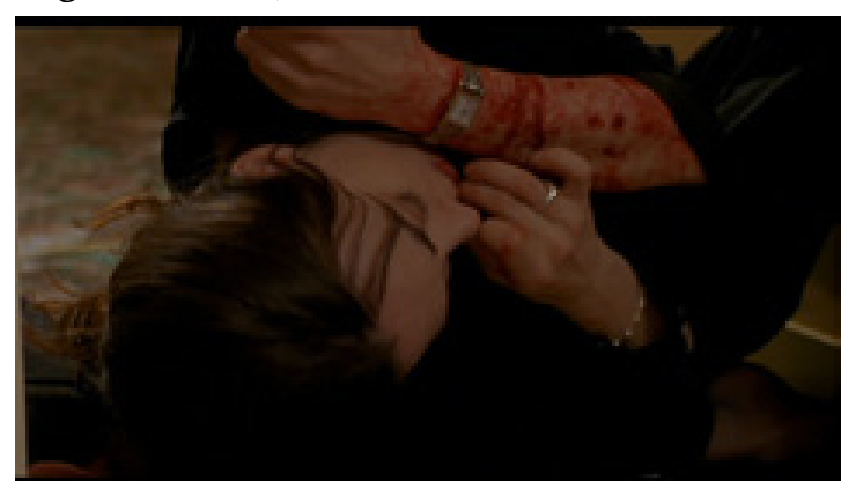

Fig. 3

"The unleashing of inner impulses.”

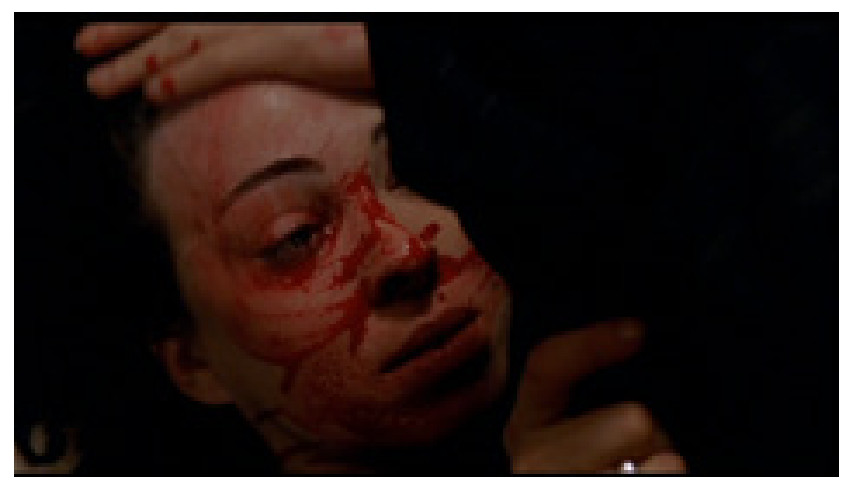

Fig. 4

"The textural implications of the image." 
In the scene that takes place in the hotel room, Esther's desire for selfempowerment finds a primary means of expression in her movements, as they symbolize her denial of a body ruled by logic and rationality in favor of a body subjected to the unrestricted drives that inhabit it. By connecting the fleeting nature of the impulses that run through the body to their visible expression at the surface of the skin, Brian Massumi's work on the concept of "affect" offers the possibility to connect the unfurling of arresting corporeal images to Esther's intimate desire to create a new identity for herself. Massumi calls "affects," or "intensities," actions that do not respond to any pre-established scheme and that are detached from any idea of logic or causality. He opposes "intensity" to what he calls "depth" and corresponds to conscious, thoughtful actions:

Intensity is embodied in purely autonomic reactions most directly manifested in the skin - at the surface of the body, as its interface with things. Depth reactions belong more to the form/content (qualification) level [...]. They [depth reactions] are a conscious-autonomic mix, a measure of their participation in one another. Intensity is behind that loop, a nonconscious, never-to-conscious autonomic remainder [...]. It is narratively de-localized, spreading over the generalized body surface, like a lateral backwash from the functionmeaning interloops travelling the vertical path between head and heart (Massumi 85).
In the film, "intensity" is first made visible through Esther's unnatural body movements and the way she occupies the space of the frame. Her body is presented as pure intensity, only guided by the unrestrained impulses that rule the frantic cutting and eating of her own flesh, as well as the contortions she resorts to and that see her in the most unlikely postures. ${ }^{4}$ The rhythm of the scene is entirely articulated around the different stages pertaining to Esther's experimentation with her body, so that the human figure no longer appears to be regulated by standard codes of behavior, but is instead perceived as an autonomous entity that has evolved to become "[...] a body passing from form to formlessness, becoming a deformed and unrecognizable entity from which, in turn, form emerges" (Beugnet 34).

The ever-changing quality of the body and the flow of images it generates are also addressed by the sensuous investment of the representation that operates through a multi-layered composition. The entire scene functions on a series of textural sensations that heighten our perception of the body's physical changes; the black pants cut by Esther first reveal the pallor of her skin which, in turn, is cut open and from which bright red blood starts dripping, which Esther then smears over her face. As a consequence, we become especially aware of the interpretative possibilities achieved through the transformation of textures and surfaces, as Esther's desire to subvert the aesthetic concept of beauty "[...] spins a series of bodily images that eradicate all sense of fixed 
corporeal limits or boundaries" (del Río 162).

The unleashing of Esther's impulses is also accompanied by a noteworthy shift in the relation between body and frame, as it appears that the former is no longer subjected to the limitations of the latter, but is shown capable of generating its own space. Again, if the focus on the numerous acts of self-inflicted torture recalls horror's fascination for the spectacle of the body in pain, de Van's film displaces the significance of the representation from the visual excess induced by such a spectacle to the potential for selftransformation that arises from this seemingly enclosed space. Consequently, the idea of entrapment and the freezing of the action usually connected to the technique of the close-up are negated in favor of the establishment of a space where the transformed body can freely express its uniqueness.

In Deleuze and the Cinemas of Performance, Elena del Río has noted that the on-screen spectacle of the female body need not be considered as the simple objectification of a character by the cinematic apparatus, but should instead be perceived as carving out a space within the fiction for the body to escape stillness and produce its own meaning by allowing subjectivity to emerge:

[...] spectacle does arrest narrative, but such arresting by no means inhibits the force of the body. If anything, it favors the unleashing of that force by freeing the body from the tyranny and the rigidity of narrative requirements. Spectacle in this sense is no longer a framed view or fetish, for it indeed becomes an actively dislocating or deforming force (del Río 33; my emphasis).

A similar process is at work in the scene where Esther is cutting and eating pieces of her skin; the frame does not constitute a limitation to the expression of the character's uniqueness anymore, but rather conveys the idea of limitless possibilities associated with corporeal transformation. This unique connection between body and frame is strengthened in another scene, towards the end of the film, where we see Esther half naked, looking at her reflection in a standing mirror. Her face and body are covered in blood and her body is shot in very unusual, animallike postures as she is seen crouching and arching her back the way a feline would. If the mirror in this scene acts as a secondary frame, its purpose is not to increase the character's entrapment within the fiction, as it usually does, but to create a space where the body can freely perform outside a pre-established frame of moral conduct.

In this respect, it is interesting to note that the vertical lines of the mirror recall the verticality that characterizes Esther's work environment, with the shots on the tall glass buildings at the beginning of the film. Whereas the introduction of verticality in these shots serves to convey the character's entrapment in a society ruled by work and social norms 
of conduct, the lines of the mirror do not enclose the body within a world of rules and regulations, but carves out a space within the fiction for the character's subjectivity to emerge and take control of the representation. In so doing, "[...] the body is shown capable of generating its own frames through its power of affection and expression [...]" (del Río 86), so that the frame does not act against the emancipation of the body but is instead an ally in its quest for seeking meaning beyond traditional means of self-expression.

This article wished to bring out the influence of horror cinema in Marina de Van's film by showing how it addresses the genre as a set of visual (the wounded body, the presence of blood and scars) and technical (the use of the close-up) elements that can be manipulated in order to lead to new interpretations of the body. In so doing, the film places the transformational capacities of the body at the center of the representation, as it presents skin as an inscribable surface whose ever-changing appearance is the visual expression of the main character's evolution and her desire to rid herself of the social and economic realities that trap her body.

If horror constitutes a visual and thematic foundation for the unsettling images that form the narrative, the article suggested that the true significance of the representation was to be found beyond the limits of the genre. Indeed, the mise-en-scène never mimics horror's codified scenarios, but instead seeks to deflect them by deconstructing some of their founding elements. Marking her body is the only way for Esther to exist in a society where "[f]lesh has become non-felt, non-experienced [and where] we have come to mistrust our senses, our passion, our inclination, our feelings [...]" (Bernas and Dakhlia 74; my translation). Because it has always considered skin as a surface that could be manipulated and transformed, horror stands as the best-suited genre to convey Esther's vital need to experiment with her body. However, with its reworking of the genre's conventions, the film is never a prisoner of this referential frame, as it generates a space within the fiction for the body's transformational powers to happen time and again. The filmed body can never be assigned a clear meaning, as it is traversed by unguarded impulses that set a variety of raw and unmediated corporeal images in motion. These images engage the spectator at a visceral level, but they never allow for a safe resolution or a finite understanding of the body on-screen. Instead, we are left amidst a world of powerful and persistent sensations, each one of them alluding to the transient nature of this body. ${ }^{5}$ 


\section{Works Cited}

Bernas, Steven and Jamil Dakhlia. La Chair à l'image. Paris: L'Harmattan, 2006. Print.

Beugnet, Martine. Cinema and Sensation: French Film and the Art of Transgression.

Carbondale: Southern Illinois University Press, 2007. Print.

Bogue, Ronald. Deleuze on Cinema. New York \& London: Routledge, 2003. Print.

Del Río, Elena. Deleuze and the Cinemas of Performance. Edinburgh: Edinburgh

University Press. 2008. Print.

Dufour, Éric. Le Cinéma d'horreur et ses figures. Paris: PUF, 2006. Print.

Massumi, Brian. "The Autonomy of Affect." Cultural Critique 31 (Autumn 1995): 83109. Print.

Palmer, Tim. Brutal Intimacy. Analyzing Contemporary French Cinema. Middletown, CT: Wesleyan Press, 2011. Print.

---. "Style and Sensation in the Contemporary French Cinema of the Body." Journal of

Film and Video 58.3: 22-32. Print.

Rouyer, Philippe. "Entretien: Marina de Van. Le corps-objet." Positif 502 (décembre 2002): 28-31. Print.

---. Le Cinéma gore: une esthétique du sang, Paris: Cerf, 1997. Print.

\section{Films Cited}

Dans ma peau. Dir. Marina de Van. Éditions Montparnasse, 2004. Film.

\section{(Endnotes)}

1 See Palmer, Tim. "Style and Sensation in the Contemporary French Cinema of the Body." Journal of Film and Video 58.3: 22-32. Print.; Palmer, Tim. "Under Your Skin : Marina de Van and the ContemporaryFrench cinéma $d u$ corps." Studies in French Cinema. 6.3 (2006): 171-81. Print.; Palmer, Tim. "In the Skin of Marina de Van." Brutal Intimacy. Analysing Contemporary French Cinema. Middletown, CT: Wesleyan. 2011: 78-88. Print.

2 In an interview she gave for the theatrical release of Dans ma peau, Marina de Van mentioned the importance of lighting in the film and explained that it played an instrumental part in the representation of the body on screen. She said: "I chose a type of lighting that would make elements stand out - what's humid or solid, what's shiny or matt which brings us back to the idea of matter (la matière)" (Rouyer, "Style and Sensation" 29; my translation).

3 In one scene of the film, Esther is seen rushing out of her office to go hide in a dark locker room of the company she works at, so that she can give in to her desire of cutting her newly sewn wound. In another scene, Esther is seen pressing a knife against her leg while at a business meeting in a restaurant, unable to resist the urge to "play" with her skin.

4 It is interesting to note that Esther's body movements in this scene act as a counterpoint to the rigid position of her body whenever we see her in her work environment. This contrast serves to highlight the two conceptions of the body that are at work within the film: the controlled and sanitized body of modern-day society and the asocial, abnormal body of unmediated drives that comes to define Esther.

5 The last shot of the film points out the impossibility to assign the body a clear meaning, as Esther is seen lying on a bed, staring blankly at the camera. The tracking out movement reinforces the uncertainty surrounding the outcome of Esther's extreme experimentation with her body. 
Romain Chareyron received his Ph.D. in contemporary French cinema and Francophone culture at the University of Alberta (Edmonton, Canada) in 2010. His research seeks to analyze the growing influence of the genres of horror and pornography in contemporary French mainstream cinema. His current research focuses on the cultural and aesthetic implications of the concept of "monstrosity" in contemporary French cinema. His work has already led to various presentations in Europe and North America as well as publications in international reviews. He currently holds a Senior lecturer position in the French and Italian department, at the University of Kansas.
Romain Chareyron a obtenu son doctorat en cinéma français contemporain à l'Université de l'Alberta (Edmonton, Canada) en 2010. Sa recherche a pour but d'analyser l'influence grandissante des genres pornographique et horrifique dans le cinéma populaire contemporain. Sa recherche actuelle porte sur le concept du "monstrueux" dans le cinéma français contemporain. Ses travaux ont donné lieu à diverses présentations en Europe et en Amérique du Nord, ainsi qu'à des publications dans des diverses revues internationales. Il enseigne actuellement à l'Université du Kansas.

Copyright Romain Chareyron. This article is licensed under a Creative Commons 3.0 License although certain works referenced herein may be separately licensed, or the author has exercised their right to fair dealing under the Canadian Copyright Act.

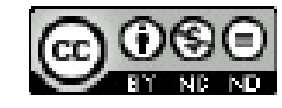




\section{THE RWANDAN GENOCIDE IN FILM, AND A SUNDAY IN KIGALI: WATCHING WITH A PIERCED EYE}

\section{PIET DEFRAEYE}

Susan Sontag reminds us that film and photography have an extremely democratic heuristic poetics, and are quasi-universally accessible for signification, though at the same time, it almost always implies a prime target audience. The many films that have come out on the Rwandan genocide (1994) are no exception. Film has been a prime access source to this bloody event and dominates, particularly in the West, our remembrance and understanding of one of the most intense and grueling political conflicts in African history. All these films struggle with a compulsive need for structured narration, whether it is in their fable, or in the visual representation itself, while the historical events were certainly not experienced as part of a linear structure. At the same time, the films aim for historical credibility, or truthfulness, which is rendered through a variety of filmic approaches. The article discusses the fictionalization of genocide through film, and problematizes the quasiunavoidable documentary effect of filmic iteration. Robert Favreau's Un Dimanche à Kigali is analyzed in greater detail, as it offers specific strategies to the problem of filmic representation of genocidal violence.
Susan Sontag nous rappelle que le cinéma et la photographie ont un poétique démocratique etheuristique qui rend leur signification universellement accessible, tout en désignant presque toujours un public cible. Les nombreux films sur le génocide rwandais (1994) ne font pas exception. Le cinéma a été une source primordiale d'accès à cet événement sanglant, et il domine, surtout en Occident, le souvenir et la compréhension de ce conflit politique qui a marqué l'histoire de l'Afrique. Tous ces films démontrent un besoin compulsif de donner une structure au récit, qu'elle soit dans la narration ou dans la représentation visuelle, et cela bien que les événements historiques ne surgissent pas selon une structure linéaire. De plus, ces films vissent une crédibilité ou une sincérité historique accomplie moyennant une variété des techniques cinématographiques. Cet article évalue la mise en fiction du génocide a travers le cinéma et questionne le quasi-inévitable effetdocumentaire que produit son itération filmique. On y analyse «Un dimanche à Kigali » de Robert Favreau pour mettre en évidence ses stratégies d'investigation de la représentation cinématographique de la violence génocidaire. 
The Rwandan Genocide in Film, and A Sunday in Kigali: Watching with a Pierced EyeThe 1994Rwandan genocide is still fresh in our memory as a shocking tragedy, a gruesome conflict, during which between 500,000 and 1,000,000 people lost their lives. The memory of it is inextricably linked with the failure of the international community to preempt or intervene effectively. When the obviously pre-meditated hostilities broke out in all their viciousness on the night of April 6 1994, after the aeroplane that carried the Presidents of both Rwanda and Burundi, Juvénal Habyarimana and Cyprien Ntaryamira, was shot down over Kigali airport, there were few journalists and cameramen in the central African country available to document a 100-day killing spree rarely observed in human history. In the chaos of this murderous violence, the handful that were based in Rwanda either immediately fled to safety or were confined to a very small action radius. The conflict, in other words, was not well documented on television and in live reportage, which, contemporary witnesses suggest, is just one of the reasons why it actually assumed its horrendous proportions. However, since the victory of the Rwandese Patriotic Front, and the relative calm it brought to this small central African country in spite of the Pan-African and regional wars that have followed the Rwandese massacres, the iteration of the Rwandan genocide by a wide variety of artists and historians has exploded into its own genre, with novels and films leading this plethora of responses, from monuments and museums, over plays and documentaries to poetry and songs. ${ }^{1}$ There is, however, no doubt about the prevalence of film in the establishment of cultural memory about Rwanda's darkest months. This article examines some of the problems of cinematography as it relates to the Rwandan genocide, particularly its historical-documentary pretensions, its prevalent drive for visual and narrative structure, its struggle with the aesthetics of violence, and its impossible task of capturing death. In the second part of the article, I offer an analysis of one film in particular: Un dimanche à Kigali (2006), a Canadianproduced movie, written and directed by Quebec director Robert Favreau, based on the eponymous novel by Giles Courtemanche.

The films that emerged were either based on witness accounts and true stories of the events or, alternatively, on cultural narratives which were themselves often narrowly or loosely inspired by historical events. The latter is certainly the case for Courtemanche's novel, originally published in 2000, six years after the genocide, and subsequently widely translated across the globe, before it became the main blueprint for Favreau's film. Michael Caton's Shooting Dogs ${ }^{2}$ (2005) is based on the tragic and shameful story of a technical school that was the site of a major debacle in the United Nations: UNAMIR's failure to meaningfully intervene at the outbreak of the genocide. Hotel Rwanda (2004) is based on a key legend that emerged from the conflict, that of hotel manager Paul Rusesabagina, whose actual memoir, 
An Ordinary Man; an Autobiography, was published in 2007, well after the film's release and subsequent box office success. Many of these films have been shown in the commercial circuit and on television, with considerable attention, so it is no surprise that these movies have been major forces in the public dissemination of knowledge about the Rwandan genocide, and as such must be approached as major cultural discourse on the conflict. So major indeed, that quite often, some of them have assumed a venerable status of historical documentation, as in the case of Hotel $R$ wanda. On the other hand, one would also expect these movies to be part of a process of healing from the trauma that the political violence in Rwanda has left. It is problematic, in this context, that their primary audience is not a local audience, but a western-based audience. I will come back to this later.

While many of the film-makers under consideration have pro-actively pursued a level of authenticity unprecedented in the regular Hollywood film, all are quick to acknowledge the reductive and manipulative interventions of the film medium itself. Michael Caton, for instance, had to reduce the number of priests that were working at the Don Bosco École technique officielle from five to one, and, as Dauge-Roth points out, "no white priests stayed at the ETO to die with the Rwandans after the Belgian forces left" (176), unlike the strategically named priest Christopher, brilliantly realized by John Hurt, who, in the end, shares the fate of the hundreds of Rwandese he is trying to protect. What may seem like minor details in the fable are ultimately crucial in the generation and management of affect in the viewer's reception and response. Similarly, Terry Georges' film Hotel Rwanda, which has by far been the most successful in terms of box office and cultural impact, illustrates well the privileged position the medium of film has in the genre of genocide memorialization, but more importantly also in the shaping of a specific and/ or collective memory of the Rwandan genocide. Hotel Rwanda, like most films on the Rwandan genocide, assertively foregrounds the fact that its narrative is based on real events, thus giving it an aura of authenticity, reliability and truth. Yet, considerable critical work has since been done on Hotel Rwanda and other films, that challenges the films' veracity and underlines choices and manipulations which make these films more palpable, and therefore successful in a Hollywood sense: they by and large generate comfortable audience positions that find their balance in easy and simplified -if not downright erroneous- understanding. As we shall see, a film like $A$ Sunday in Kigali is surely culpable of this sort of manipulation in the set-up of its fable, however, it also adopts a strategy that at the same time questions the power of its own - and therefore also the viewer's - point of view. At this point, it is useful to talk about the target audience of these films.

Susan Sontag, in response to Virginia Woolf's observations about war iconography, wonders whether there is 
a collective and identifiable "we" that responds to imagery of atrocity: "No 'we' should be taken for granted when the subject is looking at other people's pain" 7). Most of the Rwanda-genocide films, however, are clearly aimed towards a western audience and have a collective we in mind. Michael Caton-Jones says on his Shooting Dogs: "I wasn't making the film for Rwandan audience. ... I I made it for people who've never been there and have no stake or even an interest in it" ("Interview6). The film then, through its shocking narrative, is meant to jolt the western spectator into securing an interest, whether through indignation, consternation, or guilt. Raoul Peck's Sometimes in April (2004) has Rwandese characters as the key-players in its fable, yet here too, the audience in mind is a western audience. This focus is also made clear in Peck's determination to anchor his story within a narrative of colonization and its aberration, as he begins the prologue to the film with a sequence of overlapping maps that progressively show the colonization and exploitation of central Africa. The first spoken words in Peck's film are: "Where did it all begin?" The answer, the film makes clear, is to be found in the botched Belgian colonization (we see historical footage of one of the first visits of a milk-faced Belgian King Baudouin) and the subsequent paternalization of the same region in post-colonial times (the next historical clip is Bill Clinton's 2004 visit, adroitly apologizing to a class of Rwandese schoolchildren for the USA's non-intervention). Peck's rhetoric is clearly aimed at a western collective we.
The collective $w e$ of spectatorship is also defined in the dominance of Caucasian characters on the screen. Just about all films that have come out have an over-representation of white characters in their fable of this central-African event, and are focused somehow on moral dilemmas pertaining to their white characters, which, in the actual historical events played a peripheral role. Dauge-Roth calls this privileging of white identity "justifiable in that it allows for points of identification and elicits feelings of sympathy from viewers, and maybe even a sense of historical culpability" 189). One film that stands out is Nick Hughes's 100 Days, which was the first feature to come out on the Rwandan genocide in 2001, and is often referred to as the least historically revisionist. While its two lead characters are both local Tutsi - in itself a rare feat in the filmography on Rwanda-- it probably has the largest quantity of white characters casted. However, in contrast to other films, just about all of these are quite overtly racist or prejudiced, and also quite cowardly in their behavior. Hughes' film was not a great box office success, and while low budgets and amateur acting may have something to do with this, the strategy not to provide his spectatorship with an easy way-out in terms of salvation or redemption of the responsibility of the West may well be the main factor. It is all the more surprising, since his film is one of the only ones that actually provides a sense of authenticity in terms of it being less staged or acted. Produced by Rwandan film maker Eric Kabera, who lost many of his own 
family members in the genocide, the film was shot in Rwanda in the Kibuye area, using mostly locally available non-professionals, often survivors as well as perpetrators. The film is a good example of the trappings and dangers with which filmmakers are challengeh. It is clearly based on solid research - in this case the first-hand experiences of just about all that were involved in the film, including director, producers, and actors, and the film's historical reliability is very high - almost at a documentary level. Furthermore, it is unapologetic in its focus on the responsibility of the West in the lack of any serious attempt to prevent and/or effectively intervene. The film, however, struggles with its own aesthetics, as the violence shown becomes quite watchable, mostly because of cinematographic choices and the seductive allure of Hughes' expert camerawork, this in stark contrast to a very simple dialogue -in Kinyarwanda and in English, also a rare feat-delivered by charming, but often awkward actors. While the movie, like all the others, is really only available to and geared towards a Western audience, the most important impact of the film is probably on a local level, where it contributed considerably to the local economy and the (re-)establishment of local film expertise while being researched and shot. Because of its community-based genesis, it also became a catalyst for memorial discourse to find its way into the local public arena.

In more general terms, and irrespective of the implied audience, there is something very peculiar going on as to the affective and cognitive impact of these films on the establishment of a collective memory of what happened in Rwanda in 1994. Dauge-Roth aptly calls these feature films on Rwanda "vectors of memory that reach a large audience" 192), and their role in shaping and impacting on a dominant view of the Rwandan genocide afterthe-fact can hardly be underestimated. At a very basic level, we cannot forget that film, as well as photography, is an extremely democratic heuristic medium. Film and photography have a very wide base of understandability. While film analysis courses and extended exposure can certainly help in the understanding and appreciation of the depths and layers of any film, the novice and uninitiated film spectator/consumer is a perfectly legitimate authority in his or her spontaneous response to and engagement with a film. Sontag points out that critical investigative reports and bulletins, or creative responses like novels and plays have a specific readership, whose access depends on the work's "complexity of thought, reference, and vocabulary." In contrast, however, "a photograph has only one language and is destined potentially for all” 20). While we can unquestionably take issue with Sontag's suggestion here that photography (or film) has a simple semiotic system, we agree that its heuristic potentiality is indeed quasiuniversal. The image speaks for all. We cannot say the same thing of Primo Levi's novels. Furthermore, one thing that unites all films made on the genocide so far is their realist aesthetics and their fairly traditional narrative structure, 
through which the story unwinds itself with a purposeful, teleological diegesis, with clear causes and effects - often didactically explained or guided through prologues- and with unmistakable protagonists and antagonists, all moving towards a denouement - often tragic, but nevertheless presenting a fantasy of closure. While the events portrayed may be mindboggling and chaotic, there is an internal coherence at work which makes us want to see the end of the movie's plot, which we mistakenly collapse with the historical events themselves, thus allowing us to think of the fictional closure - The End - of the movie as the end and closure of the historical conflict itself. For the spectator, it is a double victory. Not only is the un-representable dystopian madnessdmolded into a comprehensible format, it is also, now, understood, appropriated, concluded, and therefore overcome. The filmmakers surveyed for this analysis use a variety of strategies, which come back time and again. The narrative structure that is geared towards closure, and is coherently framed, is usually anchored within a basic set of historical references. As indicated, these historical anchors are often explicitly provided in prologues and epilogues, or through voice-over or text slides. In some films, the historicity is provided explicitly through historical footage. Hotel Rwanda, for instance, starts with a voice-over extract from a hyper-hateful but authentic radio diatribe on Radio Télévision Libre des Mille Collines (RTML). Raoul Peck uses historical footage of King Baudouin and President Clinton's visits to Rwanda in
Sometimes in April, which he follows up with an extensive and fairly detailed - almost didactic - historical account of the conflict through a sequence of text slides. When the film proper begins, it is invariably the story of some hero or victim as anti-hero. These (anti-) heroes are presented as emblematic for what happened, they represent the wider real story that is being told, and in doing so, they acquire a super status of what Sontag calls "star witnesses, renowned for their bravery and zeal" .33). While these films want their story to be the genocide, our focus is invariably on the tragic and/or heroic fate of a particular individual or set of individuals.

A key question in all of this is obviously whether film can legitimately add anything to our understanding of what happened in Rwanda during those 100 days in 1994. Or, more succinctly: can genocide be filmed at all? As to journalistic coverage of the genocide, it was in many ways similar to the filmic evidence that exists of the Holocaust, which is the sparing but horrendous filmic documentation on the occasion of the liberation of various concentration camps in 1945: that is, after the facs! As the genocide broke out, journalistic coverage became extremely precarious in Rwanda. Local journalists were either partisan members of the extremist press -mostly Hutu-leaning, like Radio television libre des mille collines (RTM), or the monthly extremist newspaper Kangura, or were themselves targets of the violence during the height of the carnage. ${ }^{4}$ The international organization Reporters sans frontières 
estimated a total of at least 49 local journalists to be murdered in the four months following the outbreak of the murderous inferno Chrétien 389). Very few foreign correspondents remained inside the country in the first weeks after April 6, 1994, and only a handful managed to find access to the country and adequately report on what was happening during the first few weeks. Even fewer managed to stay for sufficient time to actually be able to give a fair testimony of the actual scope of things during the 100 days of carnage. Three famous examples of the latter sort are George Alagiah, Nick Hughes, and Els De Temmerman. With a dozen or so colleagues based in Nairobi, BBC-correspondent Alagiah managed to enter Rwanda in May, a full month into the atrocities, and was one of the main instruments through which the world could visually witness the most shocking aspects of the events in a mode which has become known as "let the picture tell the story." A month earlier, independent British cameraman Nick Hughes entered Rwanda for a brief period in the first week of the genocide and famously filmed an actual killing in the streets of Kigali. I will come back to this filming later in my discussion. A month earlier, precisely four days after the downing of the presidential plane, Els De Temmerman, arrives in northern Rwanda through Uganda, and facilitated by the Rwandese Patriotic Front, covers the initial events for the Dutch newspaper de Volkskrant and the Flemish-Belgian radio station BRTN as one of the very first and only journalists in the field. Only ten days later she is forced to flee to neighbouring Nairobi, Kenya, and writes in her concluding summary of fragmentary impressions, as she waits for her plane to take off from the devastations of Kigali airport: "All journalists have now left, together with the last few whites. As if the narrative stops" 32 , my translation).

Meanwhile we know that the narrative surely did not stop there, nor the historical events - however fragmented that account will forever remainnor the compounded filmic narrative that has since developed. And the specific narrative within the films under discussion certainly is never disrupted or halted. Watching these various cinematographic documents, the question whether genocide can überhaupt be filmed remains central. Sontag's assertion that to "catch a death actually happening and embalm it for all time is something only cameras can do" .59) is strange and obviously extremely reductive. To give her credit, though, she later also admits that photography only really adds to the lack of understanding of death. Photographed, the dead victims of violence "are supremely uninterested in the living: in those who took their lives; in witnesses- and in us" 125). Neither film, nor certainly photography have the capacity to actually catch anything truly meaningful of this mysterious transition, and especially of the agonies in which it is often embedded. A photograph of a corpse is often as distanced and remote as a plaster death mask, and only removes the spectator from the hauntingly liminoid character 
of death itself. The Belgian painter James Ensor has a series of paintings and drawings of his dead mother; they were kept together with a pair of photographs of her laid-up corpse, the whole collection made over the span of four or five days while his mother was laid up in their Ostend home in 1914. The photographs themselves are cold documents, without any emotion, just, as it were, providing objective proof of a cold death. His drawings and paintings, on the other hand, while still showing a cold object that has no response to the viewer and has no subject position - a cold still-life, if there ever was one! - collectively document a huge turmoil in the artist's own subject position. One of these shows his dead mother with wide open eyes in a praying pose ${ }^{5}$, the others are minimalist pencil drawings, one of them in colour pencil, that document the emotional turmoil of an intensive mother/son relationship. The 1915 painting, My Dead Mother (Todts 220) that was shortly thereafter completed, creates a wider scene, witd a tray with pharmaceutical bottles in the foreground, hinting at a process of disintegration and struggle for the aging woman, who was a dominant force in the artist's life. The image's embalming impact to which Sontag refers to in her observations about photography takes place, clearly, outside the paintings: these pictures witness and document Ensor's love for his mother and his strong mother attachment, and his subsequent sense of loss. Sitting there for hours, day after day beside the corpse of his mother, drawing her in these simple and honest works before the more formay ritualized goodbye of tha burial has produced a hugely moving documentation of his love, grief, sense of loss, as well as his sheer fascination with the corpse itself. The photographs that feature the same dead woman, on the other hand, add virtually nothing to our perception and understanding of this struggle. More to the point: the entire series of photographic documents says nothing about his mother's own struggle with death, however far removed her peaceful death in a seaside resort was from a violent massacre in the marshes of Rwanda.

Karyn Ball, in her immersive discussion of the Holocaust as an object of both inquiry as well as desire, reminds us of "the trope of unspeakability," which refers to the acknowledgment of a radical "moral otherness of the atrocities" 36), so that they cannot, in fact, be iterated. This contrasts with an abundant discursive practice, be it in film, prose, or critical discourse (this very essay in casu), which obviously transgresses the taboo of unspeakability. I would add to thi, the obvious demand for this kind of iteration in cultural consumption. She speculates that these bountiful transgressions have less to do with the moral excess of the referenced violence and more with a compulsive but "shameful fascination" with the transgression itself, which "violates deep held bourgeois codes" 37). The spectacle, re-created and re-presented in these films functions as a trap of visibility, to use Foucault's words, in which our eye is watching with a double lens: its gaze marks out its intake as "objects/ 
specimens of information and of institutional, clinical, and/or voyeuristic interest" but at the same time there is a self-consciousness of a transgressive act, which, in a way, becomes a friable and therefore vulnerable or unprotected performance of watching. Ball describes it as being "caught in the act of stooping to peer through the keyhole" .27). Or, to use the kind of imagery typical for Rwanda-films, we watch the machetes cleavg through bleeding flesh coldly and clinically, as part of an economy of knowledge (what happened?, the story, the characters, etc.) and of assimilation (we recognize and condemn the violence). Yet, at the same time, our watching itself becomes asfractious act, and has moments of hesitation, as we catch ourselves watching what must not be watched. Our watching eye is figuratively pierced: as we are safely absorbed, watching the machete-props wielded in front of the cameras and actors, our gaze also draws closer into the watching itself, and is inevitably wounded by the sharp steel points and blades that dangerously hack right in front of our spyhole, into vulnerable and mortal flesh.

Madagascar-born French journalist Jean Hatzfeld stands out among the historiographers of the Rwandan genocide for his meticulous recording of post-factum memories, traumas, testimonials, and sensibilities among surviving victims and perpetrators alike, armed not with a camera, but with pen and notepad, and a voice-recorder. In 2003, four years after having covered the final weeks of the genocide, he returns to the village of Nyamwiza, in the south-eastern Bugesera region, in search of survivors. By sheer coincidence, he also witnesses filmmaker Raoul Peck's elaborate team in the village while cast and crew face huge logistical and artistic problems trying to re-construct and put to film the refugees' horrid "reptile life in the marshes" (Hatzfeld.99) for the film Sometimes in April. This rather surrealist experience leads him to ask survivor Innocent Rwililiza about the striking absence of photographic material of the actual killings. Rwililiza's answer is startlingly self-evident and to-the-point: "There aren't any photos because there is no place for photographers on killing fields, such as our marshes and forests. No pathway of any kind along which a foreigner might slip among the killers, the killed, and those who have yet to be killed" (Hatzfel. 98-99). And Rwililiza continues with captivating clarity:

A genocide must be photographed before the killings - to show clearly the preparation, the faces of the leaders, the stockpiled machetes, the complicity of the French soldiers or Belgian priests, ... And the genocide can be photographed afterward to show the corpses, the survivor's haggard faces, the arrogance or shame of the killers, the churches piled with bones, the events in Congo and Canada, the penitentiaries, the ceremonious foreigners visiting the memorials. (Hatzfel.100)

The survivor's comments push the issue of representation well beyond the logistics of what is possible, and present it in its full ethical dimension. 
Filming death, as we know from sequences such as Saddam Hussein's execution, quickly disintegrates into voyeuristic obscenity. As already mentioned, one of the very few instances where the Rwandan killings are actually documented on film is Nick Hughes' footage of the slaughter of a father and his 20-year old daughter, later identified as Gabriel Kabaga, an auto mechanic, and Justine Mukangango.Hughesfilmed the gruesome event on April 11, 1994, from the rooftop of a French school in Kigali's Gikondo district, flanked by a distressed UN paratrooper who, helplessly, guided the cameraman to the scene through the scope of his rocketlauncher. The entire scene took no more than 20 minutes to film, yet Hughes had to turn off his camera periodically, "because he knows that he is almost out of tape and fears his batteries are running low" Thomson). 6 The grainy and jumpy footage was broadcast that same evening on $\mathrm{CNN}$, German ZDF, and Australian Broadcasting, and other channels, but without much further impact or effect. In fact, the total of three minutes and 12 seconds of video caused bigger waves years later, when Toronto Star journalist Allan Thompson managed to reconstruct the circumstances and identify both victims as well as some of the culprits. Hughes himself dealt with the ethical questions and feelings of guilt of his role as filmhistoriographer in the bloody conflict, in a 2008 documentary Iseta, Behind the Roadblock, which focuses on the circumstances of this killing and on the aftermath, including the quest for justice. The original document is obviously hugely important. Not only does it offer what is most likely the only actual killing during the Rwandan genocide documented in film, out of the hundreds of thousands of cases, ${ }^{7}$ it has also inspired many other representations in films about Rwanda, and is often quoted as an illustration of both the media's disseminating power and, at the same time, its inadequacy to actually intervene and stop the violence. It was also used as forensic evidence to incriminate, try, convict, and incarcerate one of the killers, Alexandre Usabyeyezu, who adamantly maintains he has been wrongly identified in the blurry, fragmented film, further illustrating its own inadequacy and fragility as revealing or reliable documentation. The overwhelming affect of Hughes 3-minute film, however, is the sense of jagged and quasimisplaced intrusiveness - so shocking that it brings about a paralyzing feeling of futility and ineffectiveness. Innocent Rwililiza's response to Hatzfeld's query about photographic evidence is helpful to understand the impotently explosive power of Hughes' witness document: "the intimate truth of the genocide belongs to those who lived it" (Hatzfeld 100).

wIntimacy is surely not a word that can easily be applied to the numerous Rwanda films that have come out since. The camera's voyeuristic eye is by definition an intruder into any potential intimacy, especially when it concerns death. In various films on the genocide, death is mostly present through big sweeping camera shots of piles of corpses 
along dirty roads and at road checkpoints. To add to the effect, Raoul Peck uses some historical footage, includins it in his film Sometimes in April. It comes without warning, and presents obvious ethical questions for the viewer, who has settled for the convention of reenactment and is suddenly confronted with the uncertainty of real-life imagery of carnage. Perhaps this is another occasion of watching with a pierced eye, where our perception is violently torn between the fable and the real. It is similar to Krzysztof Kieslovski's film Rouge (1994), which mixes fiction with historical footage of the sinking of the Zeebrugge-Dover ferry Herald of Free Enterprise, which capsized just outside of the Zeebrugge harbour, with almost 200 victims drowning in The Channel. The inclusion of the documentary coverage of the sinking ship in the middle of the chaos and logistical turmoil of emergency operations, in which Kieslovski smartly inserts his characters, is extremely jarring and remains completely un-acknowledged within the film. For anybody who participated in the rescue operations and the nightmarish outcome in the days following, Rouge remains a film that is hardly watchable. In Peck's case, unlike Kieslovski, the inclusion of historical footage of carnage, at least, is within a story that itself is the narrative or representation of a historical genocide. The documentary images are then used as a reinforcement of the film's non-fictionality (though the details of the story itself of Sometimes in April are fictional). Peck anchors his film in various places referencing historical events by means of direct quotation, varying from the above horrid footage, to a soccer match that was being broadcast of the eve of the $6^{\text {th }}$ of April. Clearly, all the cinematographers of the Rwandan genocide have struggled with the (re-)creation of a narrative that is not only based in historically true facts, but must also be believable as history as it develops in front of its viewers. Their films are steepedhin a rhetoric of historical conviction, promulgated by means of direct historical documentary quotation or historical explanation in their prologues and epilogues. Many of these preamble summaries or concluding commentaries comprise gross generalizations that present the conflict as a tribal clash between two homogeneous groups. I agree with Dauge-Roth's conclusion of his analysis of a number of films, that these preand post- filmic annotations have an immediate impact on the spectator's heuristic framework. They create "the promise ... of a communally shared rationality and morality, which is at least encouraging to viewers as they are about to realize that by definition, genocide destabilizes the very idea of shared humanity in its negation of a part of humanity" 208).

In the second part of this discussion, we will now have a closer look at one film in particular, which responds in a very specific way to some of the challenges outlined above. Robert Favreau's Un dimanche à Kigali is a film that, like most others, presents a coherent story, as seen through the eyes of a white person residing in Rwanda. The movie 
is an adaptation of Quebec author Gil Courtemanche's novel Un dimanche à la piscine à Kigali, which was first published in 2000 and was quickly translated into English and a handful of other languages. The novel has been widely critiqued -often negativelyabout its graphic descriptions of violence and especially its remarkable sexualization of this violence. my own analysis of the novel concludes with a nod ts its ambivalent success of restoration and representation of the events it is steeped in, and warns of the ongoing disposition in critical analysis to search for an essential truth in cultural discourse on the genocide Defraeye). Heike Härting, however, refers to the book's "pornographic gaze" and "pornographic rhetoric" (2008, p. 69-70) to denote the novelist's radical choices for a sexualized language of violence. In comparison to the book, Favreau's 2006 filmic adaptation is fairly tame, and while there is certainly sex, blood, and violence, their graphic display throughout the movie -in contrast to Courtemanche's novel-is contained and quite limited, perhaps more contained even than in any of the other genocide movies that have been produced. It may well have been a cautious attempt by the director/ adaptor not to be subjected to the same accusations of being obsessed with imagery of sex and violence. Like the novel, the film thematizes the notion of filmic documentation as a meta-filmic motif that comes back throughout the movie. Courtemanche prefaces his novel with the notice: "Ce roman est un roman. Mais c'est aussi une chronique et un reportage" (Un dimanche. 9), thus underlining the testimonial function of his writing. In Patricia Claxton's English translation of the novel, "reportage" is turned into "eye-witness report" (A Sunday viI), which foregrounds even more the authentic and reliable nature of his writing, as well as its revealing potency. The novelist wants to present a historical indictment against the perpetrators of the violence - there is no doubt in the novel that these are the radicalized Hutus - and against the shameful failure of the outside world to meaningfully attempt to preempt or intervene.

While Favreau's Un dimanche à Kigali does have a documentary function, it does not have the same indignant tone as the novel, mostly because the film's narrative is focused on the reconstruction of the love-story between the two main characters. The film is book-ended with the frantic search of protagonist Bernard Valcourt, returning to Kigali at the end of the ethnic violence, trying to find out what happened to his Rwandese fiancée, whom he was violently separated from during their frantic getaway at the outbreak of the ethnic violence three months earlier. Valcourt is a middle aged Canadian journalist played by Quebecois actor Luc Picard), who has spent three months in Rwanda to make a video documentary on the AIDS crisis, only to find himself caught up in the political and personal quagmire of genocidal aggression. While he hangs around at Kigali's posh Hotel des Mille Collines, he falls in love with a 
young and slender Rwandese waitress, named Gentille Sibomana played by Senegalese Fatou N'Diaye), who has a stereotypically Tutsi appearance, but carries a Hutu stamp in her passport, which of course, is taken away from her at one of the many checkpoints we go through in the film, so as to make her ultra-vulnerable for the upcoming onslaught. Valcourt and Sibomana, incidentally, are two of the very few characters in the film with a family name. Valcourt's surname is spread all over the film, often preceded by the epithet "Monsieur," and thus becomes a very public identity. We get to know him more as Valcourt, than by his first name, Bernard. Gentille's.surname, on the other hand, is said only twice and fleetingly in two intimate and private moments between the two lovers: once during a mock wedding ceremony, and a second time during his offering of a wedding ring to her. Just about all the others characters, Maurice, Rock, Emerita, Victor, Raphael, Manu, Célestin, Agathe, Cyprien, Modeste, Désirée, Élise ... black or white, victims or perpetrators, only have a first name. For the viewer, it makes it a challenging narrative to follow just in terms of understanding who is who. But most of all, its impact is on the emblematic function of the film. What it does is, on the one hand, level out the story of the genocide so that the fable affects everybodd, irrespective of who they are, or the name they have, or their race or ethnicity, and, on the other hand, it actually individualizes the story to very specific individuals -with a first name and a face, a smile, and a particular

IMAGINATIONS • ISSUE 4 - 1, 2013•94 impression theymakeonus, thespectator. One individual in the film is not named at all, though his name is paradoxically the best known of all: general Roméo Dallaire, military head of UNAMIR, the United Nations' inadequate and feeble military presence in Rwanda at the time of the outbreak of violence. The first long shot we have of him, in a long confrontation with Valcourt, is of his back, while he's looking out of his office window at a tense Kigali: the back of a white man in uniform, no name, and a self-declared friend of the Rwandese. Valcourt came to plead for a more pro-active engagement and for the protection of his best friend Manu, the latter apparently modeled after the Rwandese politician-businessman Landouald. The confrontation between Dallaire and-Valcourt is a bleak scene, which highlights Dallaire's impotence to do anything really preventative, yet it also foregrounds the soldier's indignation and internal rage, which again is modeled after Roméo Dallaire's post-genocidal public activism. The lack of a name of this white man in uniform, apart from the name being redundant, as especially the Quebecois and Canadian target audience of the film would have instantly recognized their general (played by well-established Quebecois actor Guy Thauvette), underscores the metonymic function of Dallaire as a westerner who witnesses and knows, and has the theoretical power to intervene, but lacks the political and financial commitment and means to do just that. Instead, he just stands by, his back to the camera, looking on the capital of a country he professes to have a deep love for. 
It is no coincidence that in this very same sequence, Valcourt emphatically declares the family name of two other people: that of Cyprien and Georgina Munyankore. ; he found them brutally slaughtered, together with their child, in the preceding scene by the Interahamwe (Hutu) militia. Apart from Gentille, these are the only Rwandese fictional characters in the film that are identified y their full names, ${ }^{8}$ and their perlocutionary being named is a stark contrast to the thousands and thousands of anonymous corpses left by the violent torrent of genocide. The consistent use of first names is even implausibly maintained in Père Louis' breaking of his confessional vows, when he declares in front of Valcourt's video-camera how Théoneste, one of the Rwandese Colonel's has confessed the total extermination plans of all Tutsi's and moderate Hutus, not sparing anyone, not even women and children, and giving priority to kill anyone in leadership, including "Emanuel, Faustin, the prime minister Agathe... ." Again only first names are used, though Valcourt seeks quick confirmation in this particular case that père Louis indeed refers to the historical Théoneste Baggasora, a retired army officer who was in charge of the Interahamwe at the time of the outbreak of violence. Père Louis's courageous testimony - "it is too late to be too scrupulous, " he justifies breaking the sacrament of confession he is bound to - provides Valcourt with a powerful document. When Père Louis asks him to take a pen and note-pad, Valcourt says: "I have something far better than that!" and takes out his video camera. The videotaped testimonial that follows becomes a central scene in the film for several reasons, as it demonstrates that the imminent atrocities had been well organized and prepared, but also that knowledge about the genocide was available beforehand for outside observers. However, more interestingly, it also highlights the power of filmic reporting itself in these circumstances. For Valcourt this is a crucial document in his engagement to help prevent the, in his mind, unilateral violence. That same evening, he is on the phone with Montreal to have Père Louis's insider informationtakenup bytheinternational press, though, not surprisingly, it is hardly acknowledged or appreciated by that same press (and its consumers), and the testimonial itself fails in its incriminating power because of the improbable use of only first names. This demonstration of Valcourt's impotent efforts reminds us of an earlier taped interview with his friend Cyprien, just before the latter's violent assassination. Cyprien admonishes him to leave the country immediately, so as to save Gentille. When Valcourt counters that he owes his many friends the successful completion of the documentary he is working on, Cyprien reminds him that "Cameras are no match to machetes," while we hear the strident slogans and demonstrations of the Interahamwe approaching in the background. The overwhelming impression the, is indeed that Valcourt, armed with his videocamera, blindly and naively failed to save his treasured Gentille from the murderous violence that is surging 
all around them. Filmmaker Robert Favreau truncates his movie with regular videotaped sequences taken by Robert Valcourt himself as part of the latter's professional preoccupation of making a documentary on AIDS in Rwanda. These insertions allow the movie to have a very flexible time reference, comprising the time before the actual start of the movie, when Valcourt returns to the killing field in order to try to find his Gentille or what became of her. We are alerted of this kind of documentation within the film by the red-coloured "Rec" or green "Play" in a corner of the image. Favreau's technique certainly underscores the montage character of the film, and thus reminds us of its post-factum artificiality, and may well help to create the conditions for some kind of aesthetic distancing so as not to get lost too much in the anticipatory dynamic of suspense the film inevitably creates, as underscored for instance by the fairly traditional use of music for specific kinds of scenes throughout the movie. Valcourt's camera work is a form of archiving, and thus gains political significance within the project of documenting a genocide, which, as we know, remained largely invisible to the outside world. Yet, what we see in these historical insertions in the movie, apart from the more intimate mementos of Gentille, are mostly interviews with witnesses and role-players of the Rwandan scene. While Valcourt's videography certainly reminds us of the restorative nature of the genocide film in general, at the same time, it also underscores its paralysis to do just that.
His failure to document any of the actual violence is a good reminder of genocide survivor Innocent Rwililiza's point that genocidal violence cannot be photographed. This is indeed the case in more ways than one in this film. There is, of course first, and foremost the practical improbability of the murderous act being available to be filmed, apart from the notorious and covert 3-minutes of documentary film shot by Nick Hughes (cf. supra). A movie, one might say, with all its tricks and technical possibilities, may then be an ideal means for a reconstructive answer to this lacuna. Yet, there is also the purely intimate aspect of death and dying that Rwililiza refers to, particularly when it concerns a violent death. Filming a butchering of another human being contains an unavoidable facet of obscenity, and incriminates not only the perpetrator as executioner, but also implicates the gazing filmmaker in this obscene incrimination as facilitator. It is no different within the framework of a fictional tale. Bernard Valcourt, with his privileged status of international co-operant, desperately wants to avoid being a facilitator of the violence he sees emerging around him, and hopes the one weapon he has, his camera, can weigh in on the events. Not so, of course: while Valcourt desperately stays in Rwanda in order to try to document, and hopefully help to prevent the worst-possible scenario, he remains powerless and utterly without any impact with his camera. His actions, in other words, are a concrete showing of the notion of white guilt that surrounds the aftermath of the genocide, of not 
having intervened, while perhaps the intention was there, and certainly the good will, but not the wherewithal, and even less the putting oneself on the line. The spectator knows (and puts his or her hope in that knowledge) that Valcourt's Canadian passport (and pack of dollars) remains a steadfast way-out ticket, as it eventually and unavoidably is, in stark contrast to the fate of his beloved Gentille.

Though A Sunday in Kigali surely makes us stand still and reflect on the events presented in the film, it foregrounds the camera's powerlessness to intervene or prevent. Moreover, in its focus on witness-documentarist Bernard Valcourt, the film is grounded in the failure of the camera to capture anything truly essential about the Rwandan genocide. As Susan Sontag reminds us: "Harrowing photographs do not inevitably lose their power to shock. But they are not much help if the task is to understand" .89). Favreau's reflexive strategy of constant insertion of Valcourt's videotaped fragments draws our focus away from the account of actual violence that we think of as the theme of the film, and makes us refocus on the re-presentation itself of this genocide, as opposed to being lost in the charms of mimetic realism of a pseudo-present within a chronological narrative. This reflexive approach also undermines the spectator's position as a consumer of violence, a perspective for which we have been well trained by television and movies alike.
If the actual theme of $A$ Sunday in Kigali is its own failure to say anything really meaningful and authentic about the genocidal violence, how then does the movie deal with the carnage of the genocide? As already indicated, the actual violence shown in the film is fairly contained, and surely in comparison to the book on which the movie is based, it seems like Favreau, who also wrote the screenplay for his film, put Courtemanche's novel through a major cleansing filter. The group-rape and butchering of Georgina and Cyprien are among the most graphic in the entire movie, and even these scenes are more suggestive than anything else. The bloodied back of Georgina on a mattress on the floor, and a close-up of a couple of machete blows that land on the back of Cyprien are sufficient to indicate what'is happening in a starkly concise and short sequence. Favreau shows us the brutal casualness of the violence of its perpetrators. His main interest, however, is the traumatic impact of this bloodshed. When Valcourt and Gentille visit Cyprien's house the next morning, they are confronted with the mutilated corpses of both parents as well as their children. Valcourt finds a torn photograph of the family, which he later crudely tapes together as the only visual proof of the very existence of these people, while the sutures of the restoration will be a permanent reminder of the murderous rupture. Gentille stumbles on symbolicallynamed Désirée, one of Georgina's children, who survived the massacre by hiding under a bed. She will adopt the girl as her own. 
The film also suggests violence and aggression at road-checks, with agitated men wielding machetes, and glimpses of piles ofbloodycorpsesin the background, though they are hardly ever a major focal point in the cinematography. This is in great contrast with other Rwandan genocide films. Michael Caton-Jones' Shooting Dogs, for instance, a film which also foregrounds the problem of documenting violence, contains a scene in which the young main character Joe witnesses a middle aged man being slaughtered with a couple of machete blows, while he himself and the BBC team he is travelling with is also gravely threatened by a road patrol. Caton-Jones' masterful camera-work and composition in this scene registers Joe's initiatory fascination with the murderous act, thus representing the film's spectator with whom he shares a compulsive need to watch. The ambushed BBC team, furthermore, are paralyzed in their documentary mission to show and have people look by the militia-men, who prevent them from filming what cannot be filmed but should be filmed. More importantly, their immediate survival from this harrowing situation seems, precisely, to hinge on their NOT looking at the murderous scene that materializes around them, and from which they can hardly divert their gaze. Another occasion for which the image of the pierced eye illustrates the visual poetics and its affect, as if we are condemned to watch with a gazing eye from which the retina is folded out.

However skillfully done by actors and cameramen, the consumption of these violent episodes in films on genocide remains problematic. While the authentic is not available, or if available must be dealt with extreme respect and caution, the re-enactment inevitably produces an obscene dynamic between what is shown and the historical gruesome event that it is modeled on, as well as between the image and its consumers. Indeed, the obscenity of such imagery makes them literally ob-scene, or off the stage, which means that they belong to a cultural discourse that is traditionally obscured or excluded, except within the context of precisely that re-enactment where their inauthentic character makes them ready for legitimate consumption. It is a sort of consumption for which we have been well trained, as this kind of imagery is more or less the basic diet in our contemporary cultural ingestion. British playwright Edward Bond, whose plays often thematize what he calls our extremely violently structured western society, uses cruelty on the stage quite often in his plays - "I write about violence as naturally as Jane Austen wrote about manners".3) - and gives it a therapeutic function, thus aiming at shaking the audience emotionally. Bond's so-called Aggro-effects are akin to terrorist tactics, their use equally justified "by the desperation of the situation" 113). While the situation was positively more desperate in Rwanda in 1994 than in Bond's industrial hinterland of the British midlands in the early seventies, using this hyper-realism on the stage has certainly a very different impact on the spectators in the theatre than on a film audience. A Sunday in Kigali tells the story of a quest for this violence, as 
it becomes Valcourt's explicit mission to find out what happened to Gentille. Moreover, it is also a quest for a format of this violence, or a form in which it can be comprehended, shown, and remembered so that its victims can also be remembered and actually be reconstituted from their annihilation.

Courtemanche's novel contains a particularly violent sequence toward the end of the book, as we learn about Gentille's suffering at the hands of her torturer Modeste, who, not incidentally, is Valcourt's ex-cameraman. In contrast, Favreau's movie adaptation presents us with a highly mediated and suggestive representation of this violence, and it is worthwhile to briefly compare. In the novel, after his return to Kigali as the forces of the Rwandese Patriotic Front sweep through the capital, Valcourt eventually gets Gentille's scribbled diary in his hands, and as readers of Courtemanche's novel, we get a gradual reconstruction of her gruesome ordeal - though, the end is left hanging, as the workbook entries stop with a quotation from Paul Élouard's Le Temps déborde: "We shall not grow old together / . . . My love so light now has the weight of torture" (2004, p. 247). Important here is that as readers, we acquire knowledge of Gentille's cruel demise in a cumulative way through several filters: that of novelist Courtemanche, whose omniscience fills in the gory details of the woman's horrific demise, that of the reader Valcourt, whose reconstructive need to know what happened is insatiable, and not in the least, the apparent calm words from the victim herself, Gentille, jotted down as haunting fragments in her diary. In his film adaptation, Favreau does not use a diary. Instead, he has Valcourt stumble into the house and shed where Gentille has been kept captive by Modeste. Through a visual re-assembly of three time references, which constantly alternate, we are witness to both Gentille's and Valcourt's point zero: the methodical, persistent and extended rape and eventual mutilation by Modeste and his Hutu Power zealots. Present-time sequences of Valcourt handling a soiled bit of dress, left on the floor as the only material left of the 24-year old woman, and emptily reaching out to her bloody imprints on the walr, alternate with the journalist's own videotaping of their courting, in which they had both decided to go for an opportunistic meeting of old versus young, white versus black, affluent versus poor: the stuff that Hollywood is made of, but now presented as an ideal, never reached. In these video-fragments, Gentille's smile of the past, which looks so much forward to the future, haunts the image of dark smudges of blood on the wall, with her voice in the background between hysterical suffering, and defiant erotic laughter, Favreau's response to Courtemanche's novel, where we read in her diary: "I've looked for pleasure in my pain" (247). The film's montage of this revelatory sequence is completed with the insertion of carefully constructed shots of Gentille's rape and torture, which we never get to see, but instead is inserted in fragmentary bits with hardly ever a direct exposure. The rape 
and torture is delicately mediated by means of shadows shots, and frames of Gentille's back as she is ruthlessly violated. These fragments are voiced over with Gentillle's words, which Robert Valcourt hears in his head, the latter being the equivalent of her diary and Paul Élouard's verse in the novel. Thus, Valcourt, together with the viewer, figuratively reconstruct and relive her suffering, but do so while not seeing, and not knowing, on a purely imaginative level. We get a filmic construction of the pierced eye metonym, where we are anxiously watching what is wounding us, and thus cannot be watched. That it is cameraman Modeste who wields the machete just completes the metonymic trope of the unwatchable see-able. Robert Favreau's mise-enscène and Pierre Mignot's camerawork here respond in a fascinating way to the notion that genocidal violence is always by definition obscured, and thus document the genocide's double obliteration: its murdered victims, as well as its obscured remembrance. The sequences of Gentille's torture, as Dauge-Roth points out, are indeed "a metonymy for the genocide's perpetration" and foreground primarily the inadequacy of what he calls "realism and its ideological trompe l'œil" 231). While together with Valcourt, we want to know, recompose and reconstruct those past events, even to the point ofmvoyeurism, such a project is doomed to fail. Remembrance can only happen through mediation, which is mostly a process of figuration. The impact of this figuration is such that it may increase the haunting effect of that remembrance.

Favreau'sfilm, ithasbecomeclear,departs in many ways from Courtemanche's novel. It does so, however, most drastically at its very conclusion. In both film as well as novel, Gentille ends up dead, but emphatically liveg on in Valcourt's memory. In the book, weakened by AIDS and other infections, and isolated because of her disfiguration and mutilation, she dies of a sudden pneumonia attack: "She is buried under the great fig tree that shades the hotel swimming pool" (Courtemanch4, A Sunday 258). In the film adaptation, Robert Valcourt continues his quest for Gentille in search of the facts of her demise, and ends up in her nativl village, where he had earlier asked her father for her hand. He meets Désirée, the girl that survived the bloody onslaught of her parents Cyprien and Georgina, and who now, in a role-reversal, takes care of her foster mother, Gentille who somehow has been able to make her way back to her village. Disfigured, infected and infectious, deathly ill, and hardly human, in her father's burntout house, which is situated in an area which otherwise looks like paradise, she reminds Valcourt of his promise "not to leave her behind," resulting in an altruistic killing: Valcourt smothers her, lying in his arms, with a pillow over her face. ${ }^{9}$ In contrast to the earlier montage and obscuration of the rape and torture - a death that cannot be rememberedthis happens in traditional realist style, re-enacted in front of Favreau's camera 
and part of the main story of the film. This scene tells us that death is most certainly available for the camera to be filmed, though only that kind of death in which one has some agency. Here are two human beings, who, while cornered because of circumstances, have taken a decision that acquires public consequence and weight. It also brings about a remarkably diverse distribution of death in the film, where people die of AIDS -Valcourt's initial focus at the beginning of his journey, when we learn that, unofficially, close to $35 \%$ of Kigali's population is seropositive, with disc-jockey Rock's spun out demise early on in the film serving as an emblematic occurrence of this kind of death. As the film goes on, death as the result of genocidal atrocity occupies the central place, and diverts Valcourt's focus away from AIDS for most of the filmic narrative. Finally, as is the case with Gentille, some people die through an act of love - Valcourt's final resolve in which he keeps his promise not to leave her behind. It is remarkable that in a film on the Rwandan genocide, the only sort of death that is extensively shown, in full realist aesthetics, is the latter one: Gentille's calm, calledfor and deliberate, tearful death on a grubby bed, in the arms of her lover.

The film ends then, with Valcourt carrying Gentille's corpse outside of the sombre hut, into the yard of her father's home, where she is to be buried. Valcourt is joined by Désirée, and we get a panoptic view of the paradisiac surroundings of this country of a thousand hills, this "little Switzerland in Africa," which is now shockingly empty of people, after 100 days of hell, leaving scars everywhere. Favreau uses light in a very special way in his film, and it acquires a major semiotic function as a sort of formal mise-enabyme. Throughout the film, all scenes that are in the performative present and document Valcourt's return after the violence, and his quest for Gentille are filmed through a light filter, making them dull and grey, showing a country in mourning, with poignantly gloomy and dim colours. This is how the film starts, as Valcourt commences his quest for answers. The dreary effect is in great contrast to both Valcourt's videography, as well as the scenes in which we flashback to the time leading up to the outburst of violence, which shows a country and people marked by sprightly, vivid colours, the green of its lush vegetation conspicuously jumping to the eye. The film ends, however, in full colour, without the dulling filter, with the brighter inner temporal frames taking over the gloomy present in a bright symbiosis. Valcourt places his video-camera on Gentille's gravemound, and plays the vivid colours of his videoclips, showing Gentille and Désirée fully and stunningly beautifully alive, while the two survivors and Désirée and Valcourt, black and white, young and old, orphan and widower, native and foreigner, look on in perfect harmony, against the backdrop of the vibrant colours of the verdant thousands hills, reflecting the central pre-genocide temporal framework of the film. To 
use an earlier trope, the watching double-layered eye of the viewer is now restored, no longer pierced by maiming steel, even the lacerations' sutures seem now to have healed.

Dauge-Roth finds in this concluding scene an emphatic statement of the camera's power serving the necessity to remember, and keeping the memory afresh:anantidoteagainst "obliteration" and the "ideology of denial" 234). It is certainly a gripping mise-en-abyme, in which the film's different temporal as well as narrative frames come together touchingly. However, to end a film on one of the most tragic socio-political conflicts in human history in this kind of intimate memorialization also comes at a cost. While Robert Favreau seems to suggest that genocidal violence cannot be photographed nor filmed, he also emphasizes the camera's ability to narrate and conjure the subjective story. The film has little room for political referencing and explication, which is perhaps best illustrated by its consistent use of first names, also when it concerns characters that are modeled after reallife players and agents in the conflict. Yet, there is subtle and consistent inclusion of historical factors, such as the hatebroadcasts of Radio Télévision Libre des Mille Collines, the shooting down of Habyarimana's airplane, the AIDS epidemic, and, rather hyperbolically, the role of the Hotel des Mille Collines as a place of refuge. Yet, in spite of the film's documentary underpinnings, it remains very much an emblematic excursion of one person's story, and this is hugely emphasized at the very end, leading some commentators to call the film "myopic" (Pevere). Contrary to what Dauge-Roth seems to suggest, there is very little "archival value" 234) in A Sunday in Kigali. The arbitrariness of the title itself, apart from its slight reduction of the novel's title,${ }^{10}$, is only a first indication of its lack of archival or even documentary value. It tells a gripping story, and does so intelligently, with a good level of self-reflection, and with an à-propos use of filmic signage. However, when at the end of the movie, the symbiotic scene between Désirée and Valcourt ends the film on a positive and hopeful note, its awkward and friable point de départ of a white journalist telling his story of not being able to save Rwanda remains even more difficult to embrace. In the end, we wonder who do we need to feel sorry for?

In her summation of twentieth century genocides, 'A Problem from Hell.' America and the Age of Genocide, Samantha Power reminds us of an incident during the many press conferences at the U.S. State department during the Rwanda crisis. Prudence Bushnell, Deputy Assistant Secretary, had recommended proactive and determined intervention just weeks before the commencement of the genocide, and gave a press conference, on April 8 1994, to warn of the escalating violence. The department's spokesperson, Michael McCurry then took over and critiqued foreign governments for not heading the message that was promulgated in Steven Spielberg's film Schindler's List, which he called a must-see so that people can 
learn that even one individual can make a difference in such an overwhelming conflict. He even recommended that the film, which had been released just the year before, be shown around the globe, as one of the most efficient measures to prevent the tragedy of genocide 392). His promotion of a US cultural product served mostly to offset Bushnell's implied criticism on her own government and its non-action. It also was no surprise to hear this spokesperson promote a foreign policy based on individual heroism, as opposed to sustained critical support of political emancipation. Be it as it may, his odd recommendation is also testimony to the power of film in our day and age. A film like A Sunday in Kigali certainly has a strong impact on our memorialization of genocide and political violence, but its seductive subjectivity in its own narrative also stands in the way of a more historically based political grasping of what happened leading up to and during the conflict. Its greatest merit, however, is in its admission that film, simply, cannot archive death and the blood that comes with it.

\section{Works Cited}

Ball, Karyn. "Unspeakable Differences, Obscene Pleasures: The Holocaust as an Object of Desire." Women in German Yearbook 19. 2003. 20-49. Print.

Bond, Edward. Plays: Two. London: Methuen, 1978. Print.

---. "From Rationalism to Rhapsody." Interview with Christopher Innes. Canadian Theatre Review 23 (1979): 108-13. Print.

Caton-Jones, Michael. "Interview." Shooting Dogs. 2006. DVD.

---. Shooting Dogs. Great-Britain-Germany. 2005.. Chrétien, et al. Rwanda. Les médias du genocide. Paris: Karthala, 1995. Print.

Courtemanche, Gil. Un dimanche à la piscine à Kigal. Paris: Éd. Denoël, 2000-2003. Print.

---. A Sunday at the pool in Kigali. Trans. Patricia Claxton. Toronto: Vintage, 2004. Print.

Dallaire, Roméo and Brent Beardsley. Shake Hands with the Devil. Toronto: Vintage, 2004. Print.

Dauge-Roth, Alexandre. Writing and Filming the Genocide of the Tutsis in Rwanda. Lanham: Lexington, 2010. Print.

Defraeye, Piet. "Twice at Peril... The Rwandan Genocide in Cultural Discourse. A Survey with Special Focus on Gil Courtemanche's Un dimanche à la piscine à Kigali." In Ursula Mathis-Moser, ed. Responsibilty to Protect. Peacekeeping, Diplomacy, Media, and Literature Responding to Humanitarian Challenges. (Canadiana oenipontana 11) Innsbrück: Innsbrück UP, 2010. 175-204. Print.

De Temmerman, Els. De doden zijn niet dood. Rwanda, een ooggetuigenverslag. Groot Bijgaarden (B): Globe, 1994. Print.

Favreau, Robert. Un dimanche à Kigali. 2008. DVD. 
Härting, Heike. "Global Humanitarianism, Race, and the Spectacle of the African Corpse in Current Western Representations of the Rwandan Genocide." Comparative Studies of South Asia, Africa and the Middle East. 28.1 (2008): 61-77. Print.

Hatzfeld, Jean. The Antelope's Strategy: Living in Rwanda after the Genocide. New York: Picador, 2009. Print.

Peck, Raoul. Sometimes in April. 2004. DVD.

Pevere, Geoff . "A view of Kigali from the Hotel Bar.” Toronto Star. 22 Sept 2006: C3. Print.

Power, Samantha . "Een problem uit de hel." Amerika, het Westen en het tijdperk van de genocide. Amsterdam: Olympus, 2003.

Sontag, Susan. Regarding the pain of Others. New York: Farrar, Straus and Giroux, 2003. Print.

Thompson, Al. "The Father and Daughter we Let down.” 2009. Web. 6 Dec 2010. <http://www.thestar.com/News/Insight/ article/616860>.

Todts, Herwig. Ensor Revealed. Brussels: ING and Fonds Mercator, 2010. Print.

\section{(Endnotes)}

1 For a critical survey of cultural discourse on the Rwandan Genocide, see my chapter "Twice at Peril... The Rwandan Genocide in Cultural Discourse,. A Survey with Special Focus on Gil Courtemanche's 'Un dimanche à la piscine à Kigali' Ursula Msthis-Moser (ed.), Responsibility to Protect (canadiana oenipontana 11. Innsbrück, Innsbrück UP, 2012. 175-204

2 The film was released in North America under the title Beyond the Gates.

3 See Ndahiro, Alfred and Privat Rutazibwa, Hotel Rwanda or the Tutsi Genocide as Seen by Hollywood (Paris: L'Harmattan, 2008).
4 For a good presentation of the role of the Rwandese media before the actual genocide, see Jean-Pierre Chrétien, et al Rwanda. Les médias du genocide (Paris: Karthala, 1995).

5 My Dead Mother IV (with wide open eyes) in Todts 218.

6 For the original footage, and Al Thompson's commentary, see http://www.thestar.com/ News/Insight/article/616860.

7 Nick Hughes himself suggests there are actually three, as reported by Dauge-Roth (222).

8 Another fictional character, Mons. Lamarre, conspicuously breaks the naming convention by being named ONLY by his surname. He is Caucasian, and a rather inept and naive bureaucrat at the Canadian Embassy in Kigali. The cast roll-call at the end of the film stands out because it only uses first names for the characters, with the exceptions mentioned here.

9 This scene is remarkably similar to the altruistic killing of the histrionic Countess, by her son Vallier in John Greyson's Lilies (1996), another Quebecois film, an adaptation of Michel Marc Bouchard's play Les Feluettes (1987).

10 The novel's title refers, somewhat capriciously, to the Sunday afternoon when Valcourt and Gentille get married, just before the escalation of the genocide. In the film, they never get married, apart from a private pledging between the two of them. 
Piet Defraeye is a drama theorist, critic and director, who taught and directed in Belgium, Toronto, and Fredericton (N.B.) and at the University of Alberta (Edmonton). He has published on Irish and Quebec Theatre, German contemporary performance, film/ opera and theatre, and gender/queer theory and Reception Theory. He has embarked on a large research project that focuses on the iteration of genocide in Cultural Discourse with a special focus on Rwanda. His most recent creation is linked to his research on genocidal representation with his theatrical adaptation of Raymond Federman's The Voice in the Closet (2012).
Piet Defraeye est théoricien du théâtre, critique, et metteur en scène. Il a enseigné en Belgique, à Toronto, à Fredericton (N.B), et à Edmonton (à l'Université de l'Alberta). Il a publié sur les théâtres irlandais et québécois, sur la performance, l'opéra, le cinéma et le théâtre allemands contemporains, de même que sur la théorie queer et la théorie de la réception. Il a entrepris un projet de grande envergure sur l'itération du génocide dans le Discours Culturel avec une concentration sur le Rwanda. Sa plus récente création en fait partie : une adaptation de The voice in the Closet de Raymond Federman (2012).

Copyright Piet Defraeye. This article is licensed under a Creative Commons 3.0 License although certain works referenced herein may be separately licensed, or the author has exercised their right to fair dealing under the Canadian Copyright Act. 


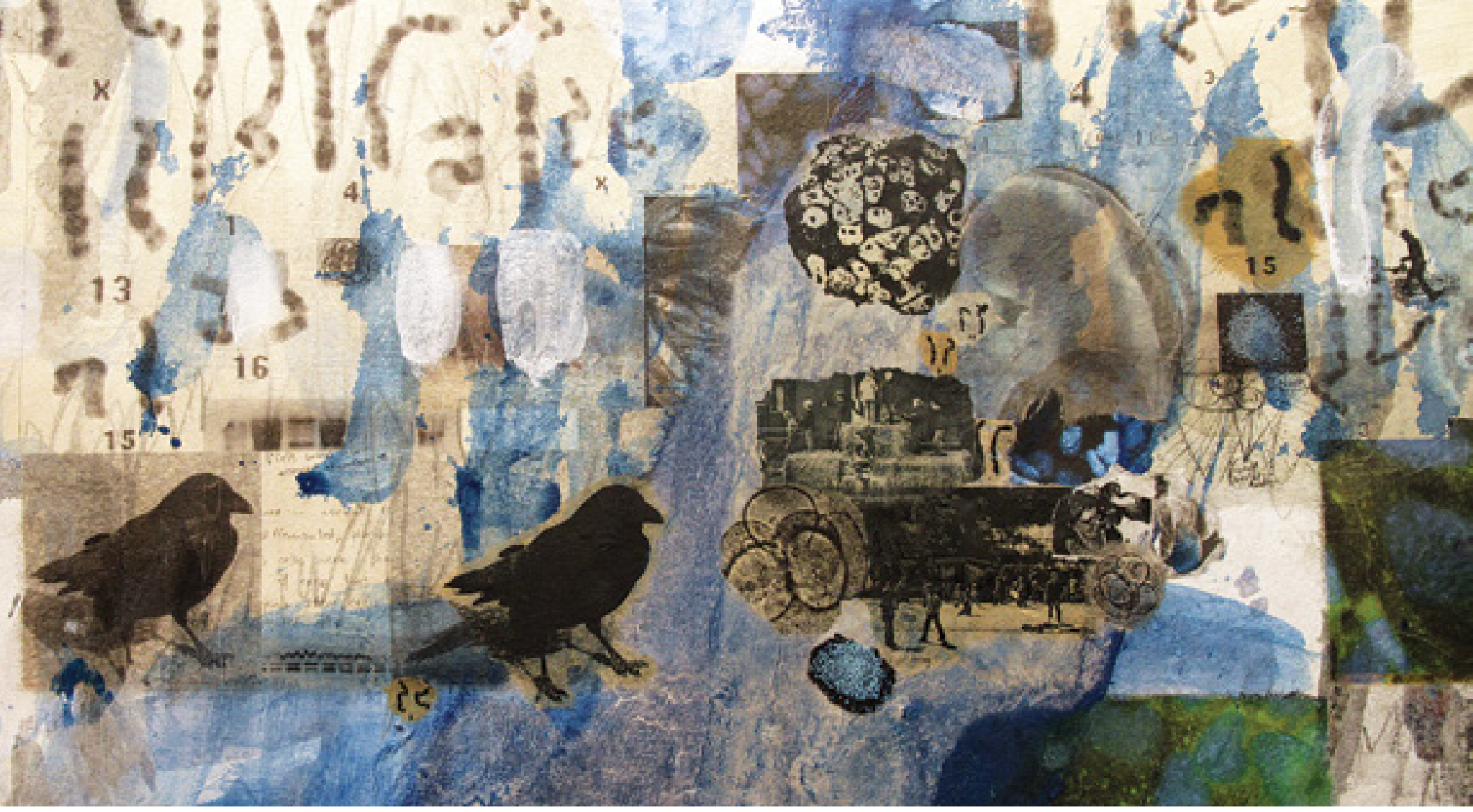

\section{LIGHTING}

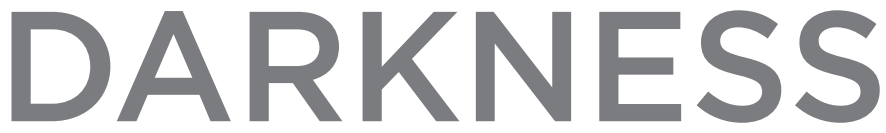

A CONVERSATION WITH ARTIST DANIELA SCHLÜTER

INTERVIEW BY ANDRIKO LOZOWY AND ELENA SIEMENS

The War in Bosnia and Herzegovina took place between March 1992 and December 1995. At the time Daniela Schlüter was a teenager struck in a deeply visceral way by the conflict and the un-deniable suffering taking place. She had already been introduced to fine arts and painting-but her humanitarian actions during the War gave her pause to meditate on the effectiveness of art as a medium for change. Since 2003 Daniela has been awarded on numerous occasions for her prints, mixed media on paper, video and book works. Daniela's work invites the viewer to immerse themselves in a fragmentary dialogue between artist and viewer-mediated by the mixed media and paper assemblages. There is a timelessness in Daniela's work as she creates balance between disparate ages, in particular in the series shown in this issue. Symbols, like trees, ladders and chromosomes collude to produce a chorus unhinged from space and time. In early 2013 Elena Siemens and Andriko Lozowy met with Daniela to discuss her work in the context of this special issue-Scandals of Horror. 


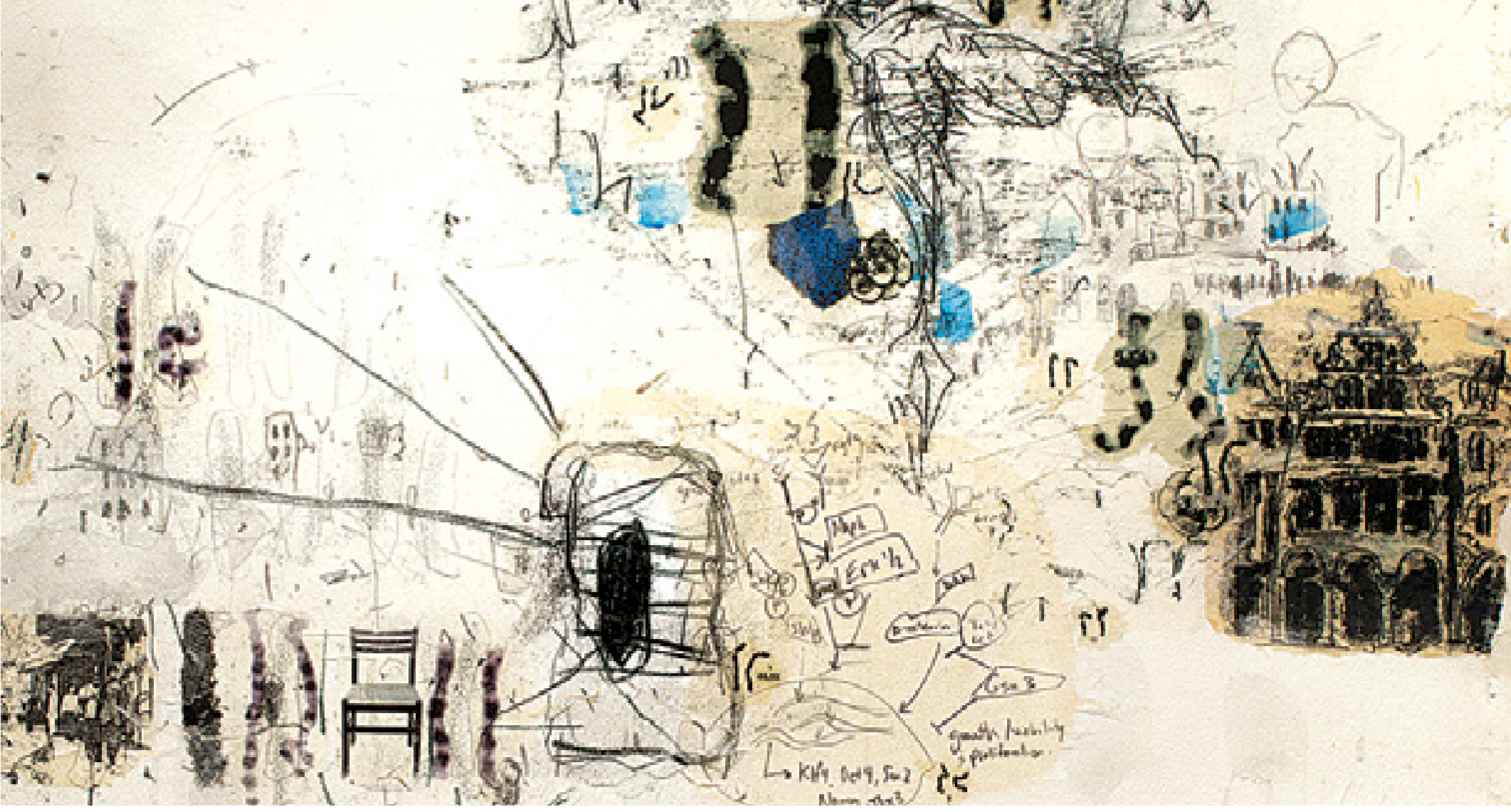

the work I create has a specific meaning the ordering - the composition emerges from the reflection. Mirrors are the most obvious point of reflection, but windows as well-they prefigure the looking. In some cases the figures in the painting emerge as passages, as ways of being looked upon as the viewer.

Q: As an artist eschewing the classic tradition of foreground and background in hopes of offering the viewer, the wider socius, something other--why painting?

A: My question in response is how much can we express through (oral/ written) language? For some time now I have been guided by the French malaise and in German Unbehagen to refer to unease, discomfort - as a means to remind myself that there is a world of the un-said. In this regard I am looking to disrupt the silence of written text and take notice of that which resides, permeates and intersects between the lines. Malaise can also be thought of as unknowing, in other words, the dark side of unease. On the other hand, knowing means safety-whereas, not knowing may mean something more mysterious and darker. For me, music and visual art attend to the registers beyond written or spoken text.

Q: Observing your work there seems to be a tendency towards darkness, bold color, a refined palate and an overall aura of intrigue.

A: In terms of darkness, in this collection for instance I had the good fortune to work with the University of Toronto scientist Paul Cassar, who is focused on stem cells. I became keenly interested in chromosomes as contemporary symbols for humanity. Chromosomes represent 

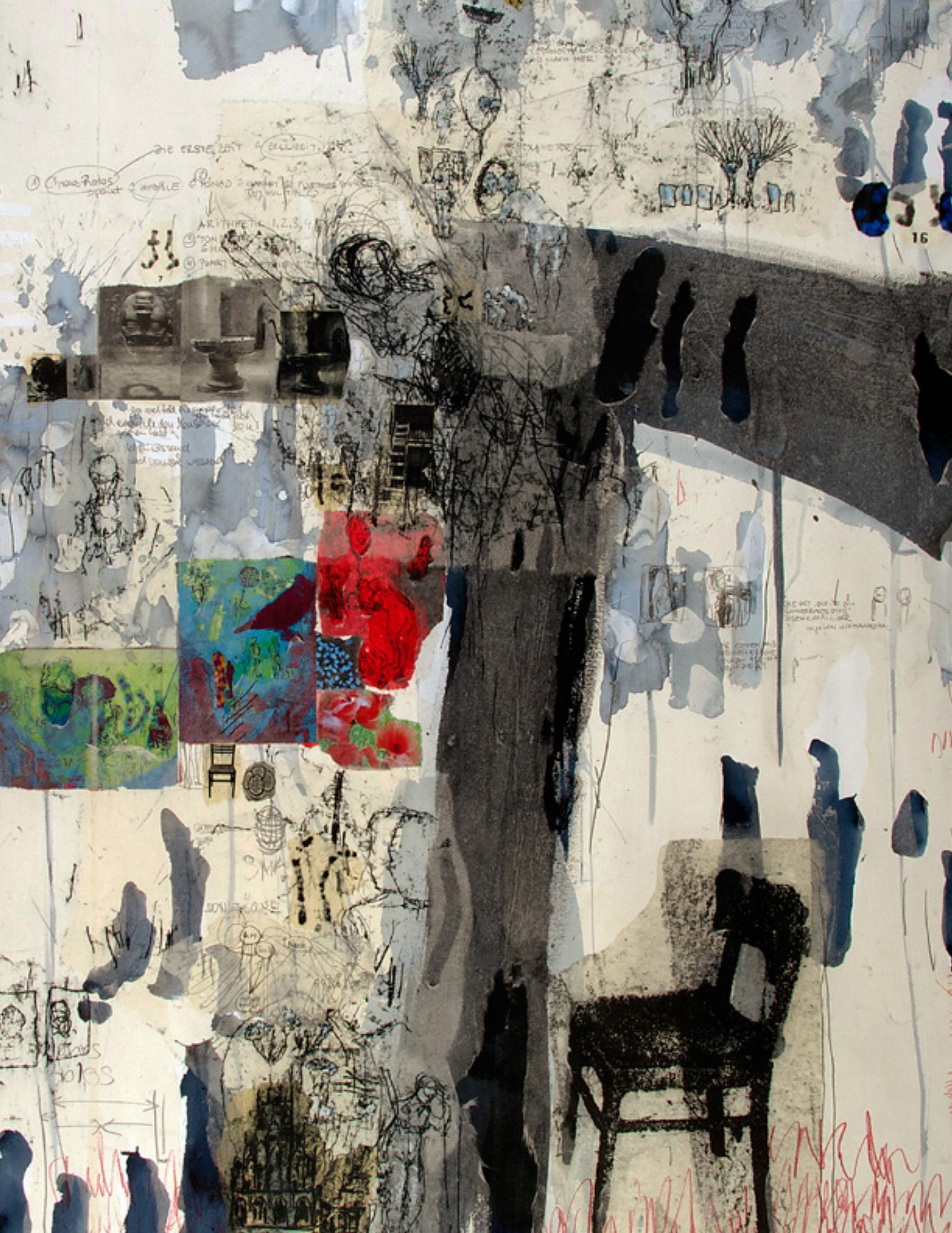
I sense there is resonance-there is a set of symbols that at once connect and disconnect, and I can access the vital power by engaging in a dialogues with a stratified-and magnified representation of self.

Q: In the biography you have provided for us here we have learned that you spent your childhood on a farm in Sudlohn, Germany. What events and encounters in your formative years have contributed to the development of your own humanistic perspective?

A: When I was 17 a group of friends and I founded a humanitarian-aid organization. It was 1992 three weeks before Christmas when we began. Almost immediately people overwhelmed us with their generositytwo 40-tonne containers of food, medicine, blankets and clothes were collected. As dangerous as it was, a group of young men drove the relief items to Slovenia and by the time they came back-between Christmas and new years the accounts and the containers were full again, so we just couldn't stop. For two years we would go down to the refugee camp. Once the border to Bosnia, a patchwork zone patrolled by young men with guns opened, we were able to get the relief to more people. Because we had led the humanitarian aid effort organizations like Amnesty and others would send more and more goods with us. For two years the cycle of colleting donations
I developed over the years after the war I found that a return to art came to represent a true offering. My humanist perspective nurtured by my experiences has propelled me to work towards manifesting creative works that aim to dislodge the primacy of text and enfold the viewer into an ongoing dialogue where attention and focus is paid to a creative meaning making effort where subjectivity is cultivated as a shared, meaning all of us, experience.

For me, hope is the ability to experience the darkness of humanity and respond through art.

Dr. Andriko Lozowy, is a photographerresearcher based in Canada. Andriko is interested in living in relation to oil, collaborative research, visual methods and post-disciplinary practices.

Dr Andriko Lozowy est un chercheur et photographe basé au Canada. Ils s'intéresse aux mode de vie liés au pétrole, à la recherche collaborative, aux méthodes d'investigation visuelles, et aux sphères post-disciplinaires.

Copyright Andriko Lozowy and Elena Siemens. This article is licensed under a Creative Commons 3.0 License although certain works referenced herein may be separately licensed, or the author has exercised their right to fair dealing under the Canadian Copyright Act.

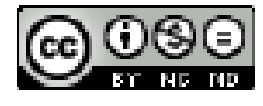




\section{CONTEMPORARY ARAB MUSIC VIDEO CLIPS}

Between Simulating MTV's Gender Stereotypes and Fostering New Ones

\section{OUIDYANE ELOUARDAOUI}

MTV was the first 24-hour cable network to continuously broadcast music videos in the 1980s, thus establishing the genre. Generally, Arab music video clips differ from Western-produced music videos, because artists are compelled to abide by the conservative cultural norms of Arab societies. However, most Arab music videos, particularly those produced in the last decade, reaffirm Western gender stereotypes intrinsic to those produced by MTV. Contemporary Arab music videos for the most part simulate an MTV aesthetic vocabulary of a gaze that features female sexuality and narratives of seduction. Some new Arab producers, nonetheless, have attempted to avoid reproducing MTVbased gender clichés, but have instead created new gender misconceptions. These productions emphasize depictions of women as untrustworthy and impetuous. Finally, I discuss how young Arab singers have constantly been confronted by the ire of regionally prominent religious figures who denounce the music videos' endorsement of "anti-Islamic" principles. I contend that Stuart Hall and Paddy Whannel's early analysis of reactions against popular music styles among British youth as a form of cultural transgression remains relevant to understanding the cultural style of Arab youth as expressed through popular musical performance.
MTV est la première chaîne de télévision à diffuser en permanence des clips musicaux 24/24 dans les années 80, établissant ainsi le genre. Généralement, les clips musicaux arabes diffèrent des clips occidentaux parce que les artistes se sentent obligés de respecter les normes culturelles conservatives des sociétés arabes. Néanmoins, la plupart des clips musicaux arabes, surtout ceux produits dans la dernière décennie, réaffirment les stéréotypes occidentaux du sexe hérités de ceux produits par MTV. En général, les clips musicaux arabes contemporains imitent le vocabulaire esthétique de MTV en lien avec la sexualité féminine et l'art de séduction. Certains nouveaux réalisateurs ont essayé d'éviter les clichés sur le sexe crées par MTV, mais ils ont créé des idées falsifiées à leur place, à savoir, des représentations où la femme est impérieuse et n'est pas digne de confiance. Cet article montre que les artistes arabes doivent sans cesse défier les personnalités religieuses locales dénonçant l'approbation des principes « anti-islamiques » qu'ils voient dans ces clips musicaux. On emploie ici les stratégies d'analyse de Stuart Hall et de Paddy Whannel, développées l'origine pour démontrer que la musique populaire est une forme de transgression culturelle de la jeunesse britannique. Ces stratégies se avèrent fort utiles afin de comprendre le style culturel de la jeunesse arabe exprimé dans la musique populaire. 
MTV was the first 24-hour cable network to continuously broadcast music videos in the 1980s thus establishing the genre. Music videos are typically short in duration, deploy cinematic camerawork and fast editing techniques as well as post-production computerized effects that have attracted viewers (Goodwin 60). MTV-style music videos are also characterized by the fragmented nature of their narration and characterization and do not usually embrace the classical Hollywood cause and effect-oriented narrative pattern. They also rarely feature full-fledged protagonists and villains because their focal point is the showcasing of the star. As a result of their lack of narrative coherence and motivational characters, the possible meaning that can usually be deduced from music videos is contingent on the juxtaposition of visual objects in relation to singers (Vernallis 138). Generally, Arab music video clips] differ from Western-produced music videos, primarily because artists are compelled to abide by the cultural norms of Arab societies. Arab television is usually censored for the depiction of sexuality, graphic violence and, in the case of Saudi Arabia, any reference to religion other than Sunni Islam (Rinnawi 29). In addition, contemporary Arab music clips have found inspiration in music sketches characteristic of Egyptian films of the 1950s and 1960s.

Most Arab music videos, however, particularly those produced in the last decade, reaffirm Western gender stereotypes intrinsic to those produced by MTV. Contemporary Arab music videos for the most part simulate an MTV aesthetic vocabulary of a gaze that features female sexuality and narratives of seduction. In this regard, relevant to Angela McRobbie's analysis of the concept of post-feminism that rationalizes the objectification of female bodies in different platforms of popular culture by the logic of personal choice, the stagnant sexualized images of Arab female singers have been often justified by the same rhetoric of "free will.. Some new Arab producers, however, have attempted to avoid reproducing MTVbased gender clichés, but have instead created new gender misconceptions. These productions emphasize depictions of women as untrustworthy and impetuous. In these clips, women typically take advantage of a kind, caring man, but in the end choose an abusive and heartless one. These new gender stereotypes generally refer to a female lack of personal integrity instead of perpetuating clichéd sexualized representations of women. In this context, I draw on McRobbie's analysis of "new sexualities" promoted by youth magazines, among other popular media outlets, that shun conventional prejudiced images of women on the one hand, while emphasizing women's sexually lustful tendencies on the other.

In the end, I examine public controversies through an analysis of the reactionary discourse of religious figures as well as a number of media experts and academics. Just as the depiction of gender and racial relations in music videos have evoked criticism in the Western media, Arab youth music 
videos have been attacked for their focus on the physical and sexual attributes of female singers and models at the expense of promoting progressive social and cultural values. In addition, young Arab singers are constantly confronted by the ire of regionally prominent religious figures who denounce the music videos' endorsement of "antiIslamic" principles. Stuart Hall and Paddy Whannel's early analysis of reactions against popular music styles among British youth as a form of cultural transgression remains relevant to understanding the cultural style of Arab youth as expressed through popular musical performance.

\section{The Classical Format of Music Clips in the Arab World}

The modern prototype of Arab music video clips is partly inspired by the musical performances that dominated Arab films and theatrical performances of the 1950s. Media professional Moataz Abdel Aziz points out that staged performances or music sketches in early Egyptian films of the 1950s used to be the central attraction to audiences. They typically featured the most popular music artists, such as Abdel Halim Hafez, Mohamed Fawzy, Shadia and Najat Saghi(29). Moreover, due to the colorful political events of the 1960s and the 1970s, political and national songs were among the most successful audio records, specifically Abdel Halim Hafez's and Umm Kalthum's national songs such as Hekayat Sha'b (Story of a People), Fidaii (Freedom-fighter) and Sawt Biladna (Our Country's Voice).
While discussing the effects of political events during that period on the thematic qualities of songs, Mounir Alwassimi, the former head of the Egyptian Musicians' Union, affirms that songs "[were] very much influenced by the social, political and the economic order of the day. Production venues were aligned with the politics of the regime and worked within its directives in most case(92). By contrast, contemporary Arab music is seen as largely apolitical and based on the commercial success of songs (Hammo142). It should be noted that the apolitical nature of the lyrics in most contemporary Arab music videos is shored up by an emphasis and fascination with the iconography of the performer.

The emergence of Egyptian television in the 1960s initially diminished the popular role that Egyptian radio used to play as the source for Arab songs. In contrast to the radio age where listeners had to rely on their own imagination regarding the appearance of the singer and band, television facilitated the audience's visual recognition of the performer in relation to visual effects that include lighting and décor (Nassar 7273). In fact, the period of classical Arab music identified as the "goldentaring lasting from the early fifties till the late seventies, was known for its main characteristic of being tarab. The most accurate English equivalent to tarab is "art music," which implies the intrinsic artistic value of music. The word tarab, as "art music," also refers to the strong effects of "enchantment" and "ecstasy" experienced by the audience (Racy 6). 
Also, the singers or artists during that time period were seen as divinely gifted because of their unique vocal aptitudes and their ability to emotionally engage the audience. In addition, audiences were assumed to be musically informed or samiah, possessed of an intuitive knowledge of the auditory and technical features of "good" music and express their enchantment with the songs through their facial expressions and verbal exclamations (Racy 40-41). This, however, has completely changed today, given that the physical appeal of singers has become the most viable criterion for success. According to some local intellectuals and music professionals, this transformation from a primarily auditory genre to an increasingly visual one has led to the disappearance of "clean art" associated with classical singers such as Mohammed Abdel Wahab and Abdel Halim Hafez. By contrast, the contemporary approach to "singing with the body" by young Arab singers has become widely popular (Alwassimi 94).

The contemporary model of Arab music video clips began to emerge in the late 1980s on largely government-owned Arab television stations. This genre catered to the growing population of Arab youth, who demonstrated their interest in watching music concerts and entertainment TV shows. The national Egyptian television channel aired a music program that presented staged musical numbers of the famous classical Egyptian singers. Along with this traditional music style, a new Westerninspired music trend began to take shape in the Arab media sphere. As Andrew Hammond explains, "The late 1990s saw a second wind for Arab pop. With the advent of Arabic satellite private stations, pop video culture has taken off and new sounds have developed that are much closer to Western pop but still distinctively Middle Eastern" (150-151). Arab music producers came to realize that the key point for the success of music performances is to introduce modern techniques while simultaneously adhering to local tastes in terms of music rhythms and lyrics (Abdel Aziz 85). Perhaps unsurprisingly, the older generation was less tolerant of the visual content of modern video clips that they considered violating essential cultural norms.

References to sex and religion in the Arab media were studiously avoided, particularly any criticism or negative portrayal of Islam. Despite the presence of a significant Arab Christian population, particularly in the Levant area, media productions typically emphasize the social and religious conditions of Arab Muslims. Further, positive representations of atheism, heresy and magic are generally forbidden. Moreover, scenes depicting explicit sex, nudity, revealing clothing for female characters as well as the use of obscene language are generally censored because they challenge Islamic practices that enhance traditional moral values and endorse modesty in clothing, speech and behaviors (Shafik 34-35). In more conservative Arab countries like Saudi Arabia, depiction of gender mixing and the presentation of unveiled women 
are subject to censorship (Kraidy, "The Social and Political Dimensions of Global Television Formats” 295).

Thus, afraid of offending spectators, particularly considering that watching television is a collective family event in almost all Arab countries, the state-run television stations resisted airing music clips in order to avoid controversy in the public sphere. However, the liberal visual content of music videos found a niche in the private satellite television stations. Walid El Khashan alludes to this phenomenon in an ironic way as he says:

There is a difference between what a "grounded" (terrestrial) national TV channel can broadcast and the greater freedom-of aesthetics and taboo-breaking-enjoyed by channels deterritorialized via satellite. Traditional "grounded" channels (for example Egypt's Channel 1 and Channel 2) show "safe" clips, while satellite channels show the hot stuff. (270)

I should also emphasize that during roughly the same period, Arab youth were exposed to international music channels, particularly the American music conglomerate MTV and the European music television channel VIVA. MTV has been able to reach 140 countries around the globe with the claim that it presents Western images with "local essence." In fact, the American music corporation asserts that its main slogan is "think globally, act locally" (Banks 266). Nonetheless,
Jack Banks points out that MTV's main goal is to increase its source revenues. Banks believes that MTV's commercialbased music video model has impacted local markets rather than adjusted its format to correspond to their cultural specifics (266).

Subsequent to their exposure to Western pop music styles, Arab youth rapidly became avid consumers of private Arab music TV channels that include Melody Arabia, Melody Hits, Mazzika, Rotana and Rotana Clip. Music TV channels in the Arab world only began to emerge in 1992 and by 2009 included some seventy channels (Kraidy amd Khalil 58). Techniques such as fetishism and exhibitionism, that MTV music videos have long been famous for, are easy to discern in the Arab music clips shown on these local music TV channels. On the other hand, a new group of Arab producers are now attempting to shun MTV's gender clichés. These music directors usually avoid framings that objectify the bodies of female singers. Instead, they rely on familiar narrative patterns and fashionable but relatively modest clothing of female singers to gain the highest possible viewership. In this respet, Marwan Kraidy and Joe Khalil state that "with their content clearly inspired by Western counterparts and with a transnational audience that spans Arab societies with various degrees of social liberalism and conservatism, music channels were from the beginning at the forefront of cultural translation between the global and the 1" (60). However, while adjusting the iconography of the music video clips to 
approximate the Arab cultural context, subtle new gender misconceptions have developed which tend to depict women as lacking an integral personal character thus being more susceptible to transgressive behavior.

\section{Simulating MTV's Gender Stereotypes}

Several highly-acclaimed Arab singers, such as Asala, Hani Shaker, Angham, Latifa, Wael Jassar, Kadem Saher, and Fadil Shaker, present video clips that conform to the mainstream norms of the Arab culture. Clips by these singers are often shot outdoors, emphasize beautiful natural landscapes and employ intriguing storylines to catch the attention of young viewers. For instance, the songs of the Lebanese singer Wael Jassar are habitually characterized by nostalgia and melancholy. Two of his recent music videos, Mchit Khalas (You Walked Away) 2005 and Youm Zifafik (On Your Wedding Day) 2007 are about his break up with a woman he loves, but whose wedding to another man he later attends. Similarly, Asala relies on sensationalist stories in order to compensate for the frequent lack of young female dancers. In one of her latest music clips Meta Shoufak (When Will I See You?) 2004, she plays the role of an angel spreading love everywhere she goes while in Feen Habibi (Where is My Beloved?) 2005, she is portrayed as a loving mother travelling the world in search of her lost son and the story ends with her reuniting with him after he has become a successful young man. While lip-synching is not a frequent convention in these Arab music video clips, directors tend to overuse closeups of the singers' faces. For example, Asala's clips are punctuated by the close-ups of her face at the beginning and end of her videos. The same holds true for the well-known Egyptian female singer Angham in which her face, particularly her "expressive" eyes are featured in extreme close-ups in several of her music clips. This approach matches the romantic themes of the majority of Angham's songs, such as Omry Maak (My Life with You) 2003. Several of these singers, especially Asala and Kadem Saher, are famous for performing the long poetic lyrics of renowned Arab poets, particularly the regionally popular Syrian poet Nizar Qabbani.

Along with this relatively modern trend, there has been a growing movement of young singers headed by Haifa Wahbi, Aline Khalaf, Nicole Saba and Ruby who primarily rely on their physical attributes and glamorous image for success. In fact, even the relatively traditionalist singers such as Asala felt the need to change her looks to fit into the video age where the artist's image has become increasingly significant. Hammond explains that "Asala was once dumpy-looking singer of long poems by poet Nizar Qabbani. Now she's shaped for the video era, with good looks and well-crafted pop tunes for private Arab music channels" (151). An important number of the singers that belong to this new music trend are Lebanese, given that Lebanon is culturally more liberal than other Arab countries. It is also the fashion and 
the most artistically creative capital of the Arab world. Hammond points out that "Lebanon has a recognized place in the Arab world as the testing ground for how the latest Western trends will be received in the on" (273). Lebanon has habitually been the Arab country that takes the initiative to produce and broadcast Westerninspired entertainment TV genres. For example, LBC (Lebanese Broadcasting Center) has aired different seasons of Star Academy, the Arabic version of American Idol, which led to public debates though the show has been adjusted to fit the Arab cultural context. The regionally diverse participants, who live together in a mansion named "the Academy" where they take music, dancing and theatre classes, have separate gender rooms and are strictly forbidden to flirt or show a sexually provocative attitude.

Therefore, Lebanon could be seen as a site where Western visual prototypes are reproduced but in a more transcultural manner for the aim of making them culturally acceptable in the Arab milieu. In this regard, Marwan Kraidy pointed out the existence of creative adaptation that involves institutional and cultural agencies in his analysis of the way Star Academy has been adapted to appeal to local audiences in Lebanon and across the Arab world. Kraidy argues that the popularity of Star Academy cannot be separated from the political circumstances of the Arab world. He suggests that the enthusiastic voting participation from the Arab youth when nominations take place in the academy reflects their thirst for effective participation in the public life where their voices would be truly counted rather than maligned as part of a fictionalized $90-98 \%$ majority. Kraidy suggests that Star Academy has created a hybrid context in which the traditional and the modern have been contested. Kraidy claims that this alternative modernity is seen as rival, given that it challenges the religious, social and political norms of Arab societies. He points out that reality TV shows in the Arab world "have spurred heated controversies about the role of Islam in public life, Western cultural influence, gender relations and political participation" (Kraidy, "Rethinking the Local-Global Nexus through Multiple Modernites," 31).

The same can be argued regarding the presence of the imported style of music videos on the private Arab TV channels. Despite the fact that Arab music videos have retained local elements in terms of technique and content such as the use of the 'ud (the Arabic lute) and the frequent featuring of belly dancing, media critics and public figures, as I will discuss later, see them as incompatible with mainstream Arab social norms. In any case, Arab viewers, to a certain extent, accept the culturally divergent ideas initiated by young Lebanese artists for the reasons mentioned earlier. Accordingly, the Lebanese exmodel Haifa Wahbi, known only by her first name "Haifa" is one of the most significant pioneers of this new music trend. While most of the Arab singers that belong to this liberal current 
are quite young, Haifa constitutes an exception since she started her singing career in her thirties and reached the peak of fame in her mid-thirties. The explanation might be her notable physical beauty as well as her ability to get big music production companies to produce and sponsor her CDs and later her music clips.

The standards of female beauty in Arab mass media have been influenced by the European prototype of beauty in terms of clothing, hair style and skin color starting from the early twentieth century. Walter Armbrust examined the physical representation of women in popular Egyptian magazines of the 1920s and 1930s, such as al-Fukaha (The Humor) and al-Sarih (The Sincere). Armbrust remarks that the majority of the sexually attractive women depicted in the magazine covers embrace a European look, discerned in their liberal clothing (such as short dresses and décolleté), hair fashion and skin color, and such a depiction was commercially used to attract more readers. Armbrust builds an analogy between these representations of female Arab beauty to the physical attributes of the female singers and models in modern music videos, while also assuming that music videos have simply reproduced the same standards of female beauty of earlier decades. He provides the example of Maysam Nahas, a contemporary aspiring Lebanese singer that embodies the European look through her blond hair, revealing clothes and relatively fair skin color. According to Armbrust, modern Arab music videos have perpetuated early "sexualized European looks" for similar reasons of maximizing pro(234235).

Armbrust's analysis of the criteria for feminine beauty criteria that dominate Arab mass media is quite pertinent, as a large number of contemporary pop music figures such as Roula Saad, Razan, Madeline Mattar and Noura Rahal, are blond, have fair skin color and they wear color eye contacts to endorse their "European" look. All these singers are Lebanese. Lebanon is not only the primary site of fashion, as explained earlier, but it has also become known as one of the capitals for plastic surgery in the Arab world (Fattah 278). These Lebanese female singers represent what is currently known in the Arab media culture as the "Lebanese look," which is generally characterized by having a high small nose, full round lips, and high tattooed eyebrows.

However, in addition to this category of European-looking female singers, there has been a very recent move towards adopting a more "Arab look" by the most popular singers including the controversial Nancy Ajram, Haifa Wahbi and Ruby, as well as other prominent singers, such as Elissa, Cyrine Abdelnour, Maya Nasri and Dolly Shahine. These stars have assumed an Arab look exemplified in their long dark hair and their continuous use of culturally-specific make-up, particularly the kohl, black eye paint usually applied to the outside edges of the eyes, to enhance their sexual appeal. Nancy Ajram and Haifa Wehbi also had 
silicone implants to endow their bodies with more curves, culturally a very sexually attractive physical attribute. In the same vein, Nancy Ajram dyed her natural blondish hair dark as part of her image transformation in the early 2000s. All of these stars have also been featured wearing the Arabic jalabiya, a long wide sleeved type of dress that comes in different fabrics and colors, in music videos such as $\mathrm{Ya}$ Romoush ( $\mathrm{O} h$ Eyelashes) 2008 and Akhasmak Ab (I'll Taunt You) 2003, though the type of jalabiya worn in these clips becomes tighter to draw attention to the singers' body curves. Hence, the present female beauty norms in the Arab music video realm are rather diverse and mixed, in which every female singer strives to have her own signature in terms of looks and music style in order to reach significant degree of fame. Nevertheless, the most popular female singers are those who embody the Arab look, including Haifa, Ruby, and Nancy Ajram, who are currently seen as the emblem of female beauty and femininity (Fattah 285).

The Western influence is more pronounced in the visual techniques used in modern Arab music videos. One can easily discern the technique of exhibitionism in all of Haifa's music video clips starting from early 2000s. In Haifa's music clips, camera angles and movements, such as the vertical pan shots, are used to highlight Haifa's physical charms. Her clip Mosh Adra Astanna (I Cannot Wait Anymore) 2008 begins with Haifa walking out of a swimming pool, the extreme close-ups and the slow depiction of her leaving water highlights every part of her body. By the end of the clip, she adopts a savage look, exemplified in her heavy make-up, red dress and untidy hairstyle, which ultimately conveys the idea that she is wild and insatiable.

Correspondingly, Haifa is often taken in high-angle shots to call attention to her fragility and submissiveness. In Haifa's Ma Toulch Li Had (Don't Tell Anyone) 2008, she is shot lying down on the floor with her glimmering nightgown as she seductively touches parts of her body. Her music clip Hassa Ma Benna Fi Haga (I Feel Something Is Going on Between Us) 2008 embraces the same content. She is shot lying on the ground as she keeps twirling in a way that underlines her bodily charms. She also poses while walking on a sunny day as the camera draws attention to her sweaty naked body. I should indicate that Haifa relies on her physical attributes, fashionable clothing, and remarkably excessive (but seen as culturally specific) make-up to cover up for the fact that her vocal aptitude is considered very mediocre not only by music experts but by almost all categories of Arab audiences including her fans who see her more as a stage performer than a singer.

Haifa's spectacular music videos and stage shows have appealed to the taste of Arab youth who see her as the epitome of feminine beauty. Haifa's style and clips are equally reminiscent of Madonna's personal mode of dancing and staging. This detail is brought up by Y. Euny Hong who notes that "a few aspects of Arab pop music are 
borrowed from Western pop. The songs of Haifa Wehbe (stage name: Haifa W), a top Lebanese pop star, have a breathy, gasping quality reminiscent of Madonna or the young David Cassiidy.” On talk shows and interviews, Haifa confirms her "feminine" and simultaneously assertive image. She usually adopts a soft vocal intonation but looks confident, and calmly refuses to answer questions that she thinks are "inappropriate" or too personal. In fact, the way Haifa presents herself in different media outlets is emblematic of Angela McRobbie's observation about the post-feminist forms of communication across various platforms of popular culture. Post-feminism, she asserts, is the belief that women's rights have already been secured and that debates about female inequality or sexist media depictions have become obsolete.

McRobbie thus remarks that feminism is presently, in most cases, evoked by young women only to be repudiated. McRobbie analzses a TV ad that features Claudia Schiffer taking off her clothes as she walks down the stairs, arguing that "this is a self-consciously sexist ad" because it stresses that the behaviors of the well-known and highly paid supermodel are out of her free choice. McRobbie contends that "by means of the tropes of freedom and choice that are now inextricably connected with the category of 'young women,' feminism is decisively 'aged' and made to seem redundant" (Tasker and Negra 27). McRobbie concludes that sexist images in media are currently justified by what she refers to as "the ethic of freedom" where relations of power are being ideologically constructed and protected by the logics of female consent and freedom of choice. In other words, the focus on the sexual appeal of women in popular culture started to be seen liberating as long as women were free to make the choice of objectifying themselves.

The image of Haifa fits very well with what McRobbie describes as "the ethic of freedom." Haifa invariably expresses her appreciation for Arab and Islamic cultural values while at the same time describing herself as a female artist who is proud of her beauty and femininity and who aspires to bring happiness to the audience through her unique singing style. Haifa enhances her assertive character by engaging in NGOs that promote social work in the region. Haifa served as ambassador for the Red Ribbon Commission that raises AIDS awareness in Africa and the Arab world in 2008. Likewise, the music clips of another Lebanese singer Nicole Saba point to their consciously culturally rebellious content, starting with the song titles. For instance, in the music clip Ana Tabee Keda (This is The Way I am) 2007, Saba dances in a very provocative manner in a nightclub amidst swaying young night-clubbers. The song's lyrics express the overall unruly mood of the visuals, she sings: "this is the way I am, this is the way I love, and I want to live this way, this is my own life, whatever happens, I will still be the way I am..." Saba's subsequent music clip Brabti (As I Like) 2008 conveys similar meaning. In this 
one, she wears a revealing nightgown as she expresses her feelings of distress towards her nagging partner. As is the case with Haifa, Saba is presented as conscious of the culturally transgressive nature of her video clips manifested in the extreme sensuality of her attire and gestures. Drawing on the rhetoric of post-feminism tenets, Saba is depicted as simultaneously powerful and feminine. Thus, to criticize the sexist depiction of the female body in this clip would be inappropriate, precisely because it is all couched within the framework of sensuality as a form of conscious choice. However, the prejudiced depiction of female characters in popular culture whether in TV ads or music video clips are currently more than often concealed under the post-feminist "ethic of freedom."

In fact, modern Arab female singers such as Haifa and Nicole Saba have attained a level of freedom of expression in terms of body and language that their earlier counterparts could not have envisioned. During the classical period of Arab music, women's decision to pursue a career as a singer was strongly discouraged because it contradicts the moral code of hasham (propriety of conduct) upon which women gain respect from their social surroundings. For this reason, the classical diva of the Arab world, Umm Kalthum, solely sung religious texts at the beginning of her career while she was dressed in 'abaya, a large flowing long-sleeved cloak that covers everything from head to toe (Racy 16-17). Umm Kalthum was thus considered as one of the most "untouchable" female singers of her era due to her socially conservative background and her culturally appropriate attire (Racy 30).

The change that took place in the Arab music video realm in terms of gender depiction is the offshoot of both the exposure to Western style of pop music as well as the rapid transformation of modern technologies that resulted in the growing importance of the image. Yet, this more vigorously liberal female attitude in music videos is tied to the increasing social and political empowerment of women in the Arab world, in general. The well-know Egyptian feminist Nawal El Saadawi founded one of the first prominent women's organizations called Arab Women's Solidarity Organization in 1982, which was composed of activists of both genders that called for the end of the long-standing social and cultural patriarchal system in the Arab world (El Saadawi 24). El Saadawi remarks that though the development of women's movement in the Arab world has been slow, the women's political groups have, with some success, advanced their agenda within the Arab nationalist movements. The main challenge for the women's groups remains the exclusion that they occasionally face from male-dominated mainstream political movements because they have been unable to form a large feminist force. Arab women have also me a significant progress in the socially more conservative gulf countries, as they have successfully entered previously maledesignated domains, such as politics 
and the workplace. For example, Nada Haffadh became the first cabinet minister in Bahrain and was later appointed Minister of Health in 2004.

In addition, the conventional appropriate gender behaviors are progressively changing. In Qatar, couples increasingly walk side by side and even hold hands in public in contrast to the previous decade where men used to walk a few steps ahead of their wives (Torstrick and Faier 114). Also, the gulf's traditional values that center on the cherishing of family relations displayed in integrity, structured nature of family relationships as well as submission to patriarchal authority are constantly in flux. The younger generations are increasingly more in favor of choosing partners from their educational and professional backgrounds than showing interest in arranged marriages, and thus the parents' role has changed from command to consultation (Torstrick and Faier).

What is also interesting is the escalating financial power of contemporary Lebanese female singers who are mostly fthe middle and working class families. For instance, Haifa and Nancy Ajram have rapidly ascended in social and economic status, after their remarkable popular success, which drove big companies such as Pepsi and CocaCola to designate them as the official representatives of their local advertising campaigns during the early 2000s. However, the image that most of these female singers represents in their music videos is very stagnant as it concentrates on their sexual and physical attributes. Hence, apart from the music videos that underline women's yearning to exhibit their bodies, there are other Arab music clips that emphasize women's own sexual desires. For example, Aline Khalaf's video clip Baadak Albal (I am Still Thinking of You) 2008 portrays her abandonment by her lover when he learns that she is pregnant. In the clip, she changes her clothes in front of the camera and exposes her naked back before her whole nude body is shown in soft focus. Then, the Lebanese singer drives her car and begins throwing her lover's ties and belts out of the car while also begging him to return to her.

Ruby's music clips are equally controversial. In clips such as Enta Aref Leib (You Know Why?) 2003, Leh Beydary Keda (Why is He keeping it to Himself?) 2004 and Kol Ma A'ollo Ah (Whenever I say Yes) 2004, Leeh Ghawi (Why Do You Like it This Way?) 2005, Omry Mastaneit Had (I Never Waited for Anyone) 2005 and Eb'a Abelny (Keep Meeting $\mathrm{Me}$ ) one would might wonder about the true nature of these clips since she performs dancing sketches in all of them and throughout the clips. Interestingly, her clips invariably consist of her dancing starting from her very first clip Enta Aref Leih (You Already Know Why) 2003 in which she playfully dances, wearing a belly dancing costume, while walking in the streets of Prague. Despite Ruby's acclaimed vocal talent, she supports her music clips by performing outstanding stage dancing. 
The music clips of Khalaf and Ruby also exemplify the trend that governs post-feminism, discussed earlier. Martin Roberts in his study of the economic and social implications of the BBC fashion TV show What Not to Wear (2001) points out that the show fosters a model of gender identity inseparable from sexual appeal, which is primarily gained through the consumption of cosmetics and "fashionable" clothing. He claims that the show endorses "one of the central tenets of post-feminist ideology: that sexual attractiveness is a source of power over patriarchy rather than the subject to it" (Tasker and Negra 233). Robin Roberts has also argued that women's ability to articulate their sexual desires through their bodies and song lyrics is an empowering feminist tool as it reverses the old tradition of reducing them to sexual ots (68). This applies to the image that Khalaf and Ruby attempt ject about of themselves, as they both consciously draw attention to their sexual desires and physical attractiveness. Additionally, in the case of Ruby, she has consistently expressed her love for dancing, an aspiration to famous Egyptian dancers, and desire to achieve a high level of professionalism in dancing. However, as McRobbie and Martin Roberts have noted, stereotypical images of women in which their physical and sexual attributes are the focal point have been justified by the rhetoric of free choice or searching for a new model of female empowerment.

\section{GeneratingNew GenderMisconceptions}

Both female and male attitudes in these music clips have been challenged by local media critics and the public. The depiction of young women who do not object the advances of male strangers is a source of local debate. Many media critics and religious clerics are worried about the transfer of these problematic behaviors to the Arab street. Their concern centers on how images that strongly conflict with the cultural norms of Arab societies get legitimized in these clips and might affect the actual attitudes and behaviors of Arab youth. In this respect, Hammond mentions the concerned statement of the Egyptian academic Ashraf Galal who contends after having looked at the modern style of Arab videos that there is an "absence of Arab identity and positive values, and there is no presence for the Arab environment, and there is a complete cancellation of higher meanings and va” (151).

A similar controversy came about with the advent of pop music videos in the West that were seen as predominantly apolitical and detached from lived reality. Hip Hop and country music among other genres have been criticized for their traditional representation of women who are mainly featured as sex objects (Railton andson 18). The images of female performers and models, considered conflicting with how women look and behave in real life, were also denounced because of their ability to spread negative social values. However, Diane Railton argues that music videos 
should not be studied merely from the perspective of how they manifest representations of reality because she refutes the idea that music videos can actually either convey negative or positive images of women. For instance, Railton states that though Pink's Stupid Girls (2006) criticizes the traditional concept of femininity as contingent on consumer culture, particularly cosmetic surgery and fashion, it also conveys the contested idea that adopting a masculine identity embodied in showing interest in contact sports is a viable means to avoid becoming a "stupid girl (34-35). Another irony, according to Railton, is the fact that this criticism of "commodified femininity" is articulated by a sexually attractive star persona (Pink) who is already entrenched in popular consumerist culture. Hence, music videos can yield different and complex feminist messages that do not necessarily fit the binary opposition of positive or negative.

To skirt grueling debates regarding the representation of gender roles in Arab music clips, some Arab directors determinably evade the focus on women's sexualized bodies. Ziad Borji's clip Aal Eih (What Did She Say?) 2007, for example, does not focus on the model's physical beauty. In fact, the model wears casual tops and pants and she is generally portrayed as an adorable fragile girl. The gender stereotype in this video clip does not pertain to the model's physical charms as much as to her unscrupulous personal code of conduct: she runs away with a man she barely knows (the
Lebanese singer) and stays with him for a few days in an isolated placter hehad rescued her from her abusive boyfriend. Unlike her previous boyfriend, he has been tremendously caring and kind. However, instead of rewarding him, she leaves him in the end and reconciles with the abusive boyfriend. The young woman, though modestly dressed, is depicted as insensitive: she dispenses with men easily and is attracted to the abusive one.

Saber Elrebai's Daet Beek (Did You Give Up?) 2008 transmits the same type of misconception about women. The clip features a young woman who attracts the compassionate Tunisian singer only to soothe her pains, as she eventually reunites with her previous uncaring boyfriend. Ghady's Redda Alay (Answer Me) 2009 carries an even more misogynist message about women's unfaithfulness: the Lebanese singer showers his girlfriend with gifts and proposes to her while the remarkably attractive girl has been planning to kill him as part of a conspiracy. Elmajdoub's music clip Ana Aamal Eiih (What Should I Do?) 2010 is centered on the same message: the Syrian singer's girlfriend let him down and starts dating one of their classmates despite the singer's extreme kindness. Similarly, Rachid Elmajid's Minek Minkeher (I am So Disappointed in You) 2010 depicts a heartbroken man who finds out that his fiancée has been cheating on him and is so hurt that he deserts her without a word. As it can be inferred, this category of clips presents a different type of gender misrepresentation. There 
is effectively no objectification of female bodies in the majority of these clips but rather an emphasis on the depravity of the personal conduct of the female characters. Women in these clips make use of gentle and caring men but choose the ones who mistreat them. As is the case with classical gender misconceptions represented in the first part of the essay, this particular depiction of women being characteristically untrustworthy and impetuous is equally problematic.

McRobbie has pointed out that a feminist critique of popular girls' magazines, such as More!, Sugar, 19 and Just Seventeen, that address gender and sexuality as their man focus, hasd gone through different stages. The first is the "angry repudiation" classical stage in which feminists criticize the objectified representation of women before more recently shifting their attention to "women's pleasure" that foregrounds women's sexual and emotional concerns. This generated a "return to the reader" for more inclusive analysis. McRobbie points out that popular youth magazines have advanced "new sexualities" by moving away from stories about romance and love to topics about safe sex and sexual pleasure. She argues that the images and articles in these magazines "break decisively with the conventions of feminine behavior by representing girls as crudely lustful young women" (50).

She also argues that the approach of magazine editors is ambiguous and contradictory: while they attempt to advance confident and unconventional images of women, they simultaneously advocate the idea that seeking the perfect body for women is essential for a successful heterosexual relationship, thus generating body anxieties for girls to achieve the assumed perfect body image. Analogous to McRobbie's argument about how the "new sexualities" depicted in popular girls' magazines have been harmful, the music videos under discussion follow the same pattern. While shunning conventional sexist depiction of female characters, they perpetuate new gender misconceptions that judge women to be lacking an integral personal character. Thus, these popular media forms, instead of decisively spurning stereotypical images of women, simply replace them with other types of gender misrepresentations that are equally injurious.

\section{Controversy in Public Life}

As stated earlier, Arab conservative entities have expressed their concern that these controversial values might transcend the fictional world of the clips to influence the mainstream cultural mode of Arab societies. In this regard, Ruby's music clips are seen as the most culturally subversive types of contemporary Arab music videos. The well-known Egyptian intellectual AbdelAlwahab Elmessiri condemns Ruby's type of music video clips of "killing" the notion of subtlety in songs that deal with romantic themes. Elmessiri is not concerned about the visual degradation of these clips as much as their lack of substantial aesthetic values 
that he believes art should embrace including music videos (165-166). For this reason, he describes these clips as simply presenting a "flesh parade" and he contends that Ruby's risqué approach advocates that "girls are cute and cuddly, receptive and playful. Ruby's character is sexy, perhaps sweet, but not inspiring" (169).

These clips have also led the Arab youth to clash with an older generation that does not only disapprove of the music clips' culturally transgressive content but believes that they have no useful message. In this regard, Kraidy and Khalil point out that there is a significant gap between the young Arab generation and their parents in terms of exposure to new media genres, as they explain:

While people who are currently eighteen years old or younger were born into the vibrant and diverse commercial satellite television era, their parents are likely to have grown up with one or two staid national channels. Elements of global media culture that are familiar to these children are completely alien to their parents (57).

Thus, this visual cultural discrepancy has put the youth in a real dilemma. Due to their strong familiarity with different types of new media, particularly the internet, Arab youth already know a great deal about the Western prototype of music videos that they cherish. For many of them, the Arab model of music video clips is catching up with the latest
Western trends of music rhythms and clothing fashions rather than importing extraneous cultural values.

In a similar context, Stuart Hall and Paddy Whannel have discussed the prejudiced social attitude adopted by the older British generation toward the popular music styles of the youth. Hall and Whannel note that as a result of their preference of particular types of popular culture (songs, films, comic etc.) the youth can be argued to have formed their own subculture that is not necessarily reverent of the traditional values of the family, school and religious institutions (Storey 6263). Hall and Whannel attribute this behavior of social non-conformity to the youth's desire to articulate "their adolescent emotional dilemma" (Storey 64). Further, the emphasis on teenage emotions is manifest in youth music through two forms. The first is the lyrics of the songs which are mostly about love (falling in love, longing for or suffering from love) and the delivery of these songs by typically young singers with whom the young audience can identify. They add that though the settings of the songs are usually not authentic, the feelings expressed are genuine and reflect the youth's emotional and social concerns. They also conclude that the youth's music, though different in character, is in kind similar to other entertainment music is in that it is "intended for dancing, singing, leisure and enjoyment" (Storey 66). They also contend that pop music plays a functional role that it is basically an emotional outlet for the youth, which 
is the reason for its typical dismissal by adults.

Hall and Whannel's observations about the British youth pop music fit well into the social prejudice that Arab pop music has faced from both the older generation and the religious clerics. Regardless of the sexist image in a number of modern Arab music clips that depict highly debatable gender relations, many of these videos serve to voice the social and emotional dilemmas experienced by the Arab youth. Saba's videos, for instance, are especially rebellious. The lyrics of Saba's songs express a yearning for freedom from all social and cultural constrictions. In Ana Tabee Keda (This is The Way I am) 2007, Saba sings "this is my character and I like it this way, my life is all mine and I should live it the way I want, I live my age by singing and loving life and I do what I want and feel, I will enjoy my life second by second. I want to laugh, dance and be happy, it is only one life and I should live it up. And I turn a deaf ear to all those who keep blaming me..." Saba's subsequent song Brabti (As I Like) 2008 conveys the same defiant message. In this one, she sings "I will do as I like, no one will control me or pull me down. Why should I believe his made-up stories and be happy with his character? No I don't like it this way, I am a woman who loves freedom and I don't want a lover who will control me, frankly no one deserves that I go to bed upset because of him. Life is a game, we either lose or win and I want to be the winner at the end..."
Saba's two songs clearly express a desire for a social acceptance even if the person is rebellious in the sense of not conforming to mainstream social norms. This is also obvious in the visuals of the clips that include the singer's untidy clothing style, strange and even ugly make-up and the depiction of young people frantically swaying in nightclubs, in addition to the fast-paced music that reinforces the rebellious ambiance. Some of Ruby's clips also attempt to speak to the emotional sensibilities of the youth despite her consistent dependence on dancing sketches. For example, in her Omry Mastaneit Had (I Never Waited for Anyone) 2005, she expresses her nonchalant spirit and readiness to fall in love with only the man who would value her feelings. Thus, following Hall and Whannel, Arab pop songs are characteristically very analogous to other national pop music. Their focal point is also the desire for love fulfillment and the fear of falling in love with the wrong person. In addition, these Arab singers are also quite young which facilitates the youth's identification with their songs and help generate more feedback from them. In fact, Ruby more than often claimed that she always provides dancing shows in her music videos because she wants to share her passion for belly dancing with other Arab young girls who equally adore the art of Middle Eastern dancing. Thus, pop Arab music is also customarily entertaining, aiming at providing space for leisure and enjoyment for the Arab youth. Also, though the general settings of contemporary Arab music videos are not as authentic as claimed to be 
given that they are detached from their cultural and geographical context, they serve to reflect the socially rebellious mood of the artists, as in the case with Saba and Ruby's clips.

What is also specific about the controversy surrounding Arab pop music is that Arab pop singers constantly face scrutiny from official religious clerics in the region. Conservative Arab communities in the gulf area have demanded the censorship of the modern style of Arab music clips. Their argument is that these music videos introduce "non-Islamic" values that might negatively impact the religious integrity of young Arabs. Patricia Kubala refers to the religious discourse that strongly condemns the dissemination and consumption of modern Arab music clips. She quotes the prominent Egyptian religious figure Dr. Yusuf alQaradawi who affirms:

Of late there has appeared a kind of female dance that is more dangerous, provocative and effective in arousing the worldly instincts [...] This has become famous on singing and amusement channels, and it has become a profitable business to those who deem permissible illicit earnings, even if [this money] is gained by dishonoring [hatk] inviolable things, and disdaining morals and degrading ethical virtues, and raising the logic of the body above that of the spirit, and treating the human as if he were an animal! (194).
Though this might be an austere statement, al-Qaradawi's concern, like that of the majority of religious authorities in the Arab world, is the assumed culturally invasive qualities of music videos that can cause the younger generation to be less reverent of their Islamic traditions. Similar fatwas have been issued regarding other types of Western-inspired TV shows, as was the case with Star Academy. Saudi religious clerics have urged Arab viewers of both sexes to stop watching Star Academy because it fosters gender mixing in the private sphere. ${ }^{2}$ The harsh criticism was due to the fear that such Westernbased TV shows "would teach women to 'display their charms' and 'lose their modesty' while leading men to succumb to their impulses and lose their status as guardians of familial honor." 3

This type of allegation also targeted the content of contemporary Arab music videos, which religious clerics see as being culturally incompatible with the Arab-Islamic context. Nonetheless, despite the fact that Saudi and Egyptian sheikhs use religious references to substantiate their fatwas that presumably aim to protect the Arab society from "external" social ills, such as adultery and gender mixing, their statements are politically-motivated. Kraidy touches on this important point when discussing the opposing stand of the religious authority Wabhabiya (Kraidy, Reality Television and Arab Politics 14) that relentlessly promotes the strictest form of gender segregation in order to preserve the ideal Islamic characteristics of both genders, 
particularly women that are seen as the bearers of national identity and family honor (Kraidy, Reality Television and Arab Politics 14). Kraidy attributes the fierce controversy that imported and Western-inspired media have evoked in Saudi Arabia to Wahhabiya's fear of losing power and public legitimacy. $\mathrm{He}$ contends that the discourse of protecting the pure Islamic practices against the conflicting ones in imported media is a façade for the religious clerics to secure their power in the Arab public sphere.

Also, with the very recent thriving of Islamist groups in the Arab world, subsequent to the public uprisings, there has been a consistent demand for reviving an Arab identity where cultural and religious authenticity are seen as the most feasible means for social development. Egypt's current president, Mohamed Morsi Isa ElAyyat, took office in June 2012. He has been a leading figure in the Muslim brotherhood, which used to be the fiercest opposing political group during Mubarak's regime. As a result of the increasing political power of religiously more conservative parties, Arab TV channels, particularly the governmentcontrolled ones, feel the need to abide by the socio-religious redlines set by those pressure entities and this applies to both locally produced and imported media. Consequently, in addition to the frowned-upon attitude that the new Arab youth music style faces from the older generation and media critics, young Arab singers feel at odds regarding the Islamists who propagate conservative views that denounce the visual content of contemporary Arab music videos.

\section{Conclusion}

Contemporary Arab music video styling has roots in the short sketches of Egyptian films produced in the 1950s and 1960s. While songs and staged musical performances of that era reflected upon contemporary political and social issues specific to the Arab context, contemporary Arab music videos emphasize the visual appeal of performers while integrating a Western prototype of pop music to the detriment of qualities that undergird national constructions of gender. In this way, several of the clips under discussion rely upon objectified images of women as part of a corporate address to commodification of the body. The sexualizedfemaleiconography presented exchanges sexism as the embodiment of the purported free will of the female performer to exhibit her sexuality. However, following McRobbie, this post-feminist address conceals the perpetuation of media stereotypes organized around gender and sexuality. Other Arab producers and singers have introduced images that generate novel gender misrepresentations that are more subtle forms of stereotyping in order to allay public controversy. As is the case with the number of American girls' magazines that shun conventional sexist images, on the one hand, and produce bigoted "new sexualities" that stress the social and sexual significance of embracing the "perfect" female body on the other, as McRobbie has 
described, these video clips highlight the depraved personal code of conduct of women rather than present them as objects of pleasure. Finally, despite these stereotyped images, some of these clips can also be seen as an alternative forms of expression that allow Arab youth to interpret their concerns and emotions, analogous to other national popular musical forms.

\section{Works Cited}

Abdel Aziz, Moataz. "Arabic Music Videos and Their Implications for Arab Music and Media." Music and Media in the Arab World. By Michael Aaron Frishkopf. Cairo: American University in Cairo, 2010. 77-89. Print.

Alwassimi, Mounir. "Arab Music and Changes in the Arab Media." Music and Media in the Arab World. By Michael Aaron Frishkopf. Cairo: American University in Cairo, 2010. 91-96. Print.

Armbrust, Walter. "What Would Sayyid Qutb Say? Some Reflections on Video Clips." Music and Media in the Arab World. By Michael Aaron Frishkopf. Cairo: American University in Cairo, 2010. 231-54. Print.

Cestor, Elisabeth. "Music and Television in Lebanon." Music and Media in the Arab World. By Michael Aaron Frishkopf. Cairo: American University in Cairo, 2010. 97-110. Print.

Banks, Jack. "Keeping "Abreast" of MTV and Viacon : The Growing Power of a Media Conglomerate." A Companion to Television. Ed. Janet Wasko. Malden, MA: Blackwell, 2005. 256-69. Print.

Dajani, Nabil H. "Television in the Arab East." A Companion to Television. Ed. Janet Wasko. Malden, MA: Blackwell, 2005. 580-601. Print.

El Khashan, Walid. "Arab Video Music: Imagined Territories and the Liberation of Desire." Music and Media in the Arab World. By Michael Aaron Frishkopf. Cairo: American University in Cairo, 2010. 265-75. Print.
Elmessri, Abdel-Alwahab. "Ruby and the Checkered Heart." Music and Media in the Arab World. By Michael Aaron Frishkopf. Cairo: American University in Cairo, 2010. 163-72. Print.

Fattah, Wael Abdel. "The Biographies of Starlets Today: Revolution in Sound and Image." Music and Media in the Arab World. By Michael Aaron Frishkopf. Cairo: American University in Cairo, 2010. 277-90. Print.

Goodwin, Andrew. Dancing in the Distraction Factory: Music Television and Popular Culture. Minneapolis: University of Minnesota, 1992. Print.

Hammond, Andrew. Pop Culture Arab World: Media, Arts, and Lifestyle. Santa Barbara: ABC-CLIO, 2005 Print..

Hong, Y. Euny. "In the Arab World, Pop Stardom Can Be A Touchy Subject." The Washington Post. 5 June 2005. Web. 26 Mar. 2011. <http://www.washingtonpost. com/wp-dyn/content/article/2005/06/03/ AR2005060301040_pf.html>.

Kraidy, Marwan and Khalil, Joe . Arab Television Industries. Palgrave Macmiln, 2009. Print.

Kraidy, Marwan M. Reality Television and Arab Politics: Contention in Public Life. New York: Cambridge UP, 2009. Print.

-. "Rethinking the Local-Global Nexus through Multiple Modernities: The Case of Arab Reality Television." TV Formats Worldwide: Localizing Global Programs. By Albert Moran. Bristol, UK: Intellect, 2009. 2938. Print.

- . "The Social and Political Dimensions of Global Television Formats: Reality Television in Lebanon and Saudi Arabia." Global Television Formats: Understanding Television across Borders. By Tasha G. Oren and Sharon Shahaf. New York: Routledge, 2012. 285-305. Print. 
Kubala, Patricia. "The Controversy over Satellite Music Television in Contemporary Egypt." Music and Media in the Arab World. By Michael Aaron Frishkopf. Cairo: American University in Cairo, 2010. 173-224.

McRobbie, Angela. In the Culture Society: Art, Fashion and Popular Music. London: Routledge, 1999. Print.

Nassar, Zein. "A History of Music and Singing on Egyptian Radio and Television." Music and Media in the Arab World. By Michael Aaron Frishkopf. Cairo: American University in Cairo, 2010. 67-89. Print.

Racy, Ali Jihad. Making Music in the Arab World: The Culture and Artistry of Tarab. Cambridge: Cambridge UP, 2003. Print.

Railton, Diane, and Paul Watson. Music Video and the Politics of Representation. Edinburgh: Edinburgh UP, 2011. Print.

Rinnawi, Khalil. Instant Nationalism: McArabism, Al-Jazeera, and Transnational Media in the Arab World. Lanham: University of America, 2006. Print.

Roberts, Robin. Ladies First: Women in Music Videos. Jackson: University of Mississippi, 1996. Print.

Sa'dāwī, Nawāl. The Nawal El Saadawi Reader. London: Zed, 1997. Print.

Shafik, Viola. Arab Cinema: History and Cultural Identity. Cairo, Egypt: American University in Cairo, 2007. Print.

Storey, John. Cultural Theory and Popular Culture: A Reader. Athens: University of Georgia, 1998. Print.

Tasker, Yvonne, and Diane Negra. Interrogating Postfeminism: Gender and the Politics of Popular Culture. Durham N.C.: Duke UP, 2007. Print.

Torstrick, Rebecca L., and Elizabeth Faier. Culture and Customs of the Arab Gulf States. Westport, CT: Greenwood, 2009. Print.
Vernallis, Carol. "Strange People, Weird Objects: The Nature of Narrativity, Characters, and Editing in Music Videos." Medium Cool: Music Videos from Soundies to Cellphones. By Roger Beebe and Jason Middleton. Durham, NC: Duke UP, 2007. 111-51. Print.

\section{(Endnotes)}

1 Music videos are known as video clips in the Arab world. I will be using both expressions interchangeably.

2 Gender mixing in the private sphere is forbidden from an Islamic point-of-view only when it takes place between men and women that are not mahrim to each other, that is they are not sisters and brothers or fathers and daughters and thus there is a possibility for them to develop a romantic or sexual relation that are considered haram (religiously forbidden) in Islam.

3 The Wahhabiya or Wahhabism is an Islamic movement that began in Saudi Arabia in the eighteenth-century by a religious reformer named Muhammad ibn Abdal-Wahh凶b, who advocated the exclusive reliance on Qur'an and Sunna (the practices of the Prophet Muhammad). Today, Wahhabism is known as a zealous religious trend that strives to revive the prophetic tradition like Salafism but is more strict in its dictation of what is haram (religiously forbidden) and halal (religiously allowed) particularly in terms of gender issues, punishment laws and dress code. 
Ouidyane Elouardaoui is a Fulbright $\mathrm{PhD}$ candidate $(\mathrm{ABD})$ in the film and media department at the University of California, Santa Barbara. Her current research interests include contemporary Arab media, melodrama and spectatorship. Her publications that include "Mexican Telenovelas in Morocco: The Localization Process and its Limitations" and "Arabs in Post 9/11 Hollywood Films: A Move toward a more Realistic Depiction?" appear in the international journal of Amity School of Communication, 2011 and in Purdue University e-Pubs, 2011.
Ouidyane Elouardaoui est doctorante Fulbright dans le département d'études du cinéma et des médias à l'Université de Californie à Santa Barbara. Elle mène des recherches sur les médias, le mélodrame et les publics arabes contemporains. Ses publications "Morocco : The Localization Process and its Limitations » et « Arabs in Post 9/11 Hollywood Films : A Move toward a more Realistic Depiction ? ", ont paru dans le journal international de Amity School of Communication et dans les e-Pubs de l'Université Purdue en 2011.

Copyright Ouidyane Elouardaoui. This article is licensed under a Creative Commons 3.0 License although certain works referenced herein may be separately licensed, or the author has exercised their right to fair dealing under the Canadian Copyright Act.

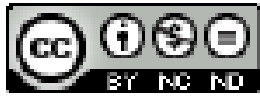




\section{Call for papers}

Imaginations invites academic articles that discuss the historical inheritances of 20th century discourses on and between images as they are in dialogue with and articulated in 21 st century cultural contexts. Potential contributions should innovatively reflect on the image. Points of departure could include new technologies, interactions between text and image, text as image, image and the self, dynamic and static images, omnipresence of screens (big and small), thinkers of the image, image across the disciplines and forms of thought (visuality, medicine, science, urban studies, political studies, gender studies, queer studies, etc.). We are also seeking, on an ongoing basis, one review essay per issue that compares three or four books on the image. Each issue of the journal will also feature one artist, and an interview with the invited/selected artist to contextualize his/her artistic contribution(s). If you are interested in conducting an interview with a specific artist, please send a proposal; if you are an artist who would like to be considered as the feature artist, please send sample work with some indication of what type of artistic contribution you would like to feature in the journal's online format. We accept papers in English and French on an ongoing basis.
La revue en ligne Imaginations est à la recherche d'articles proposant une réflexion sur la manière dont l'histoire a laissé son empreinte sur les discours dédiés à l'image, et plus spécifiquement sur les discours ancrés dans le XXe siècle. Nous nous intéressons également à la manière dont les images ont été pensées et produites, en interrelation les unes avec les autres, dans le temps et en lien avec les nouveaux contextes culturels du XXIe siècle. Les propositions de contribution devront faire montre d'une réflexion innovatrice sur le sujet. Sont bienvenues toutes propositions portant par exemple sur : le rôle de l'image dans les transferts culturels, l'intégration des nouvelles technologies, les interactions entre texte et image, le texte en tant qu'image, les liens entre image, identité et représentations, les images dynamiques et statiques, l'omniprésence de l'écran ("petit écran " et " grand écran ") dans notre monde contemporains, les penseurs de l'image, la pénétration par l'image de disciplines telles que la médecine, la science, les études urbaines ou politiques, etc. Les textes soumis peuvent être rédigés en anglais ou en français. imaginations@ualberta.ca
www.csj.ualberta.ca/imaginations/ 

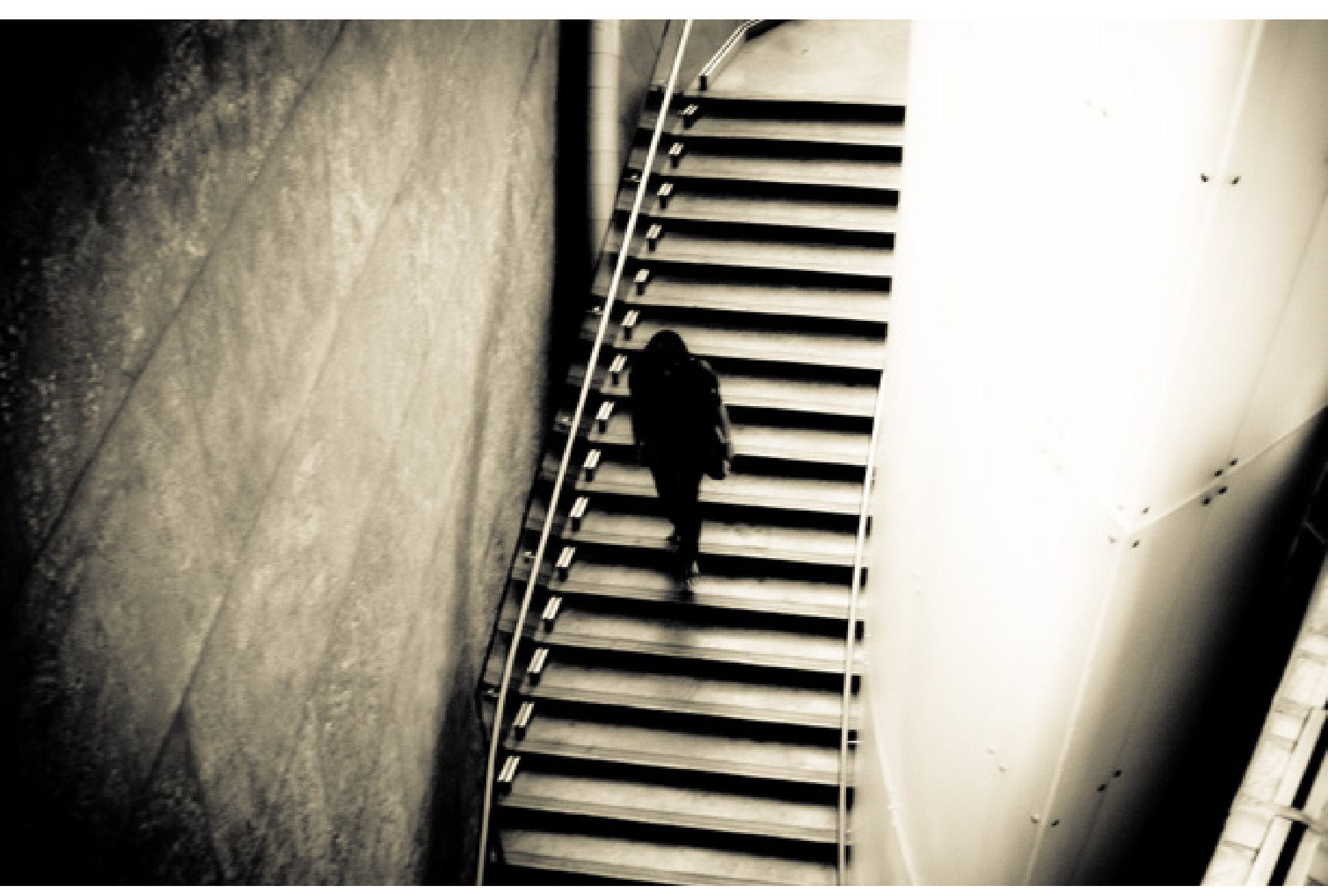

IMAGE - ELENA SIEMENS 